\title{
SUMMARY OF THE \\ PLANNING, MANAGEMENT, AND EVALUATION PROCESS \\ FOR THE \\ GEOTHERMAL PROGRAM REVIEW VI CONFERENCE
}

October 1988

\section{DO NOT MICROFILM \\ COVER}

Prepared for:

U.S. Department of Energy

San Franctsco Operations Office

1333 Broadway

Oakland, California 94612

Prepared by:

Meridian Corporation

4300 King Street, Suite 400

Alexandria, VA 22302

Under contract:

No. DE-AC03-86SF-16299 


\section{DISCLAIMER}

This report was prepared as an account of work sponsored by an agency of the United States Government. Neither the United States Government nor any agency Thereof, nor any of their employees, makes any warranty, express or implied, or assumes any legal liability or responsibility for the accuracy, completeness, or usefulness of any information, apparatus, product, or process disclosed, or represents that its use would not infringe privately owned rights. Reference herein to any specific commercial product, process, or service by trade name, trademark, manufacturer, or otherwise does not necessarily constitute or imply its endorsement, recommendation, or favoring by the United States Government or any agency thereof. The views and opinions of authors expressed herein do not necessarily state or reflect those of the United States Government or any agency thereof. 


\section{DISCLAIMER}

Portions of this document may be illegible in electronic image products. Images are produced from the best available original document. 
SUMMARY OF THE

PLANNING, MANAGEMENT, AND EVALUATION PROCESS

FOR THE

GEOTHERMAL PROGRAM REVIEW VI CONFERENCE

October 1988

Prepared for:

U.S. Department of Energy

San Francisco Operations Office

1333 Broadway

Oakland, California 94612

Prepared by:

Meridian Corporation

4300 King Street, Suite 400

Alexandria, VA 22302

Under contract:

No. DE-AC03-86SF-16299 
Executive Summary .................. ifi

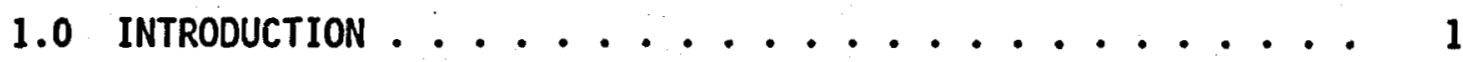

1.1 Purpose of the Conference ............ 2

1.2 Conference Approach and format. .......... 2

2.0 PR VI IMPLEMENTATION ................ 4

2.1 Advanced Planning ................ 4

2.1.1 Budget and Accounting System Design and

Coordination ............ 4

2.1.2 Program Development ........... 4

2.1 .3 Program Promotion . . . . . . . . 7

2.1.4 Pre-Registration ....... 8

2.1.5 Hotel Selection and Negotiations ....... 9

2.1.6 Air and Ground Transportation ......... 9

2.2 Conference Management ............... 9

2.2.1 Final Agenda ............. 9

2.2.2 Final Invitees List $\ldots . . . .99$

2.2.3 On-Site Inspection of Hotel Facilities/Services - 10

2.2.4 On-Site Registration .......... 10

2.2.5 Conference Facilitation......... 10

2.2.6 Post Conference Wrap-up .......... 10

2.3 Conference Evaluation and Proceedings ....... 10

2.3.1 Conference Evaluation ............ 11

2.3.2 Proceedings Preparation . . . . . . 11

3.0 PR VI MANAGEMENT ................. 12

3.1 Management Organization and Responsibilities..... 12

3.2 Resource Requirements ............ 12

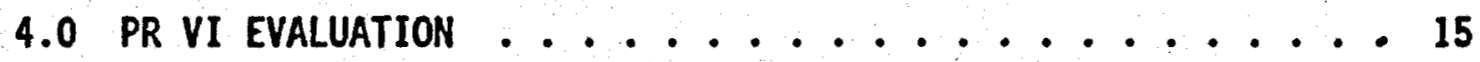

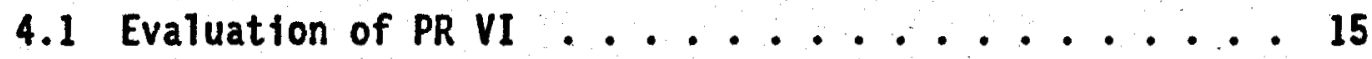

4.2 Recommendations for PR VII Planning ....... 16

5.0 PROPOSED SCHEDULE FOR PR VII PLANNING PROCESS . . . . . 19 


\section{APPENDICES}

Page

APPENDIX A - ADVANCED PLANNING CHECKLIST . ......... A-1

APPENDIX B - CONFERENCE MANAGEMENT CHECKLIST . . . . . . . B-1

APPENDIX C - CONFERENCE EVALUATION AND PROCEEDINGS CHECKLIST . . . c-1

APPENDIX D - REQUEST FOR APPROVAL OF DOE SPONSORED CONFERENCE

UNDER $\$ 200,000$ OR 100 ATTENDEES ........ D-1

APPENDIX E - FINAL AGENDA FOR "PROGRAM REVIEW VI: BEYOND

GOALS AND OBJECTIVES" ............ E-1

APPENDIX $F$ - CONFERENCE EVALUATION RESPONSES ........ F-1

APPENDIX $G$ - COVER AND TABLE OF CONTENTS OF PR VI PROCEEDINGS . . G-1

\section{LIST OF EXHIBITS}

\section{Exhibit}

1

Conference Management Team Organization ....... 13

2 PR VI Conference Budget ............... 14

3. Proposed Schedule for PR VII Conference Planning ... 20 


\section{EXECUTIVE SUMMARY}

The purpose of this document is to present an overview of the planning, facilitation, and evaluation process used to conduct the Geothermal Program Review VI (PR VI) conference. This document was also prepared to highlight lessons learned from PR VI and, by utilizing the evaluation summaries and recommendations, be used as a planning tool for PR VII. The conference, entitled "Beyond Goals and Objectives," was sponsored by the U.S. Department of Energy's (DOE) Geothermal Technology Division (GTD), PR VI was held in San Francisco, California on Apri1 19-21, 1988 and was attended by 127 participants. PR VI was held in conjunction with the National Geothermal Association's (NGA) Industry Round Table. This document presents a brief summary of the activities, responsibilities, and resources for implementing the PR VI meeting and provides recommendations, checklists, and a proposed schedule for assisting in planning PR VII.

The purpose of the conference was to provide an overall programmatic and management review of the Geothermal Research and Development (R\&D) Program and to generate industry interest and involvement in the program activities. The conference was designed to provide an exchange of information between government and industry specialists to incorporate industry input into the federal decision-making process regarding research priorities and directions for the next several years.

The basis of the conference was the "Draft Statement of Programmatic Objectives" document, recently prepared by DOE/GTD to guide the R\&D program over the next five to seven years. Conference presenters addressed the objectives established for their particular research area, described how these objectives will be met, and discussed the resulting cost reductions anticipated for geothermal power by the mid-1990's. Unilike previous program reviews, PR VI was organized to emphasize overall programmatic and management aspects of the geothermal R\&D program. Limited emphasis was placed on review of technical findings and progress. A "special issues" session was also held to address other issues of general interest to the geothermal arena.

The Director of the U.S. DOE Geothermal Technology Division served as chairman of the conference. He was assisted by a co-coordinator from GTD, and a co-coordinator from the DOE San Francisco Operations Office. Meridian Corporation provided conference coordination support.

One important aspect of this report is the inclusion of a PR VI evaluation survey, as a planning tool for PR VII. The evaluation survey requested feedback from participants regarding various aspects of the conference. Generally, the responses were favorable and the conference was deemed a success. Attendees noted that the overall conference organization was wellplanned and executed and were especially pleased with the west coast conference location and the participation by industry through the NGA Round Table. Some comments revealed that even more industry participation was desirable. Valuable observations were made about the content and direction of the conference and many of those suggestions are presented in the recommendations for planning PR VII section of the report. 


\section{SUMMARY OF THE PLANNING, MANAGEMENT, AND EVALUATION PROCESS FOR THE GEOTHERMAL PROGRAM REVIEW VI CONFERENCE}

\section{$1.0 \quad$ INTRODUCTION}

The purpose of this document is to present an overview of the planning, facilitation, and evaluation process used to conduct the Geothermal Program Review VI (PR VI) conference. This document was also prepared to highlight lessons learned from PR VI and by utilizing the evaluation summaries and recommendations, result in a planning tool for PR VII.

The conference, entitled "Beyond Goals and Objectives, " was sponsored by the U.S. Department of Energy's (DOE) Geothermal Technology Division (GTD) and was held in San Francisco, California on April 19-21, 1988. The meeting was held in conjunction with the National Geothermal Association's Industry Round Table.

This document presents a brief summary of the activities, responsibilities, and resources for implementing the PR VI meeting, and provides recommendations, checklists, and a proposed schedule for assisting in planning PR VII, to be held in March 1989. Specifically, the following topics are addressed:

- PR VI Implementation -- summarizes activities conducted in the advanced planning, management, and post-conference phases of this conference.

- PR VI Management -. overviews the management and coordination responsibilities of various individuals and organizations involved in the contractual and programmatic management of PR VI.

- PR VI Evaluation -- summarizes the evaluation responses from the participants and provides resulting recommendations for PR VII.

- Proposed PR VII Schedule -- provides a proposed schedule for planning and preparation of PR VII.

The PR VI conference was coordinated by the Director of the DOE Geothermal Technology Division (GTD). He was assisted by a co-coordinator from DOE/GTD and a co-coordinator from the DOE San Francisco Operations Office (DOE/SAN). Planning, management, and evaluation support were provided by Meridian Corporation.

The Program Reviews have been held annually by GTD for six years. These meetings serve to assemble all of the researchers and managers involved in the Geothermal R\&D Program to review activittes, measure progress, and generate inputs for outyear planning for program management by GTD. 


\subsection{PURPOSE OF THE CONFERENCE}

The purpose of the conference was to provide an overall.programmatic and management review of the Geothermal Research and Development (R\&D) Program and to generate industry interest and involvement in the program activities. The conference was designed to provide an exchange of information between government and industry specialists to incorporate industry input into the federal decision-making process regarding research priorities and directions for the next several years.

Specifically, the conference was designed to:

- Serve as a programmatic and management review of R\&D conducted under the DOE Geothermal program. Conference presenters addressed the objectives established for their particular research area and described how these objectives will be met and the resulting cost reductions anticipated for geothermal power by the mid-1990's.

- Introduce GTD's new document: "Draft Statement of Programmatic Objectives of the Geothermal Technology Division" and the IM-GEO (Impacts of Geothermal Research) cost-of-power computer model; explain how they will guide the Geothermal Research and Development Program for the next five to seven years; and show how achieving these objectives will result in quantifiable reduced costs of geothermal power.

- Provide a forum through which conference participants can obtain an up-to-date report on DOE's geothermal R\&D programs and can explore significant new R\&D thrusts.

- Provide an opportunity to compare and exchange information with coworkers and interested participants, thus facilitating the transfer of technology among federal, state, and local governments, as well as industry and academic organizations.

- Foster a technical information exchange through participation of DOE/Headquarters, Operations Offices, National Laboratories, contractor personnel, and the private sector.

- Provide communication and information exchange concerning the value of federal research work to industry.

- Provide information to the private sector concerning the technology base needed to develop competitive technologies in the critical areas required to reduce system costs, improve performance, and lengthen the lives of operating systems.

\subsection{CONFERENCE APPROACH AND FORMAT}

The basis of the conference was the "Draft Statement of Programmatic Objectives" document, recently prepared by DOE/GTD, to guide the R\&D program over the next five to seven years. Unlike prevtous program reviews, PR VI was organized to emphasize overall programmatic and management aspects of the 
geothermal R\&D program. Limited emphasis was placed on review of technical findings and progress.

The PR VI planning effort emphasized industry participation in the conference and in the DOE Geothermal R\&D Program in general. The DOE Geothermal R\&D Program Review meetings have been held in Washington, D.C. for the past two years. The San Francisco Bay area conference location was chosen because most geothermal resources, as well as geothermal operators, developers, and suppliers, are located in the West. It was hoped that a program review meeting based in the San Francisco area would be attended by a greater number of industry participants.

The theme of this year's annual program review, "Beyond Goals and Objectives," was chosen to highlight the new program goals and objectives recently developed as part of the DOE's GTD R\&D strategy assessment. These new goals and objectives are designed to reflect the influence of both industry's need for improved technology and the government's policies which determine research funding.

The usual two-day conference format was extended to two and one-half days. The major portion of PR VI, the Geothermal Federal R\&D Review, was organized into four sessions to discuss research program objectives with in the four technical areas: Hydrotherma1, Geopressured-Geotherma1, Hot Dry Rock, and Magma Energy. Each technology addressed the "Draft Statement of Programmatic Objectives" document and how the successful achievement of the goals in each area will reduce the cost of geothermal power.

In conjunction with this effort, the National Geothermal Association (NGA) held an Industry Round Table on Federal R\&D at the same location and all program review attendees were invited to attend. The President of the NGA, and moderator of the Round Table, told the audience why the NGA was established and what it hopes to accomplish. He then introduced the panel of experts that represented such areas as drilling, exploration, power plant design and construction, and international export. The panelists discussed industry's research priorities and directions for the next five years relative to the federal R\&D program. The NGA President then asked for questions from the audience, which resulted in a lively exchange of information. Following the Round Table, NGA sponsored a luncheon which featured Cal ifornia Energy Commissioner Barbara Crowley as guest speaker. The NGA Round Table and luncheon assisted in increasing the participation by industry in PR VI.

A final DOE session was held following the NGA Round Table to address "spectal issues" of general interest to the geothermal arena: Topics included government-industry cooperation, international markets for U.S. geothermal equipment and services, an explanation of the IM-GEO model, and the results and analysis of the recent National Acadeny of Sciences study concerning the issues, R\&D needs, and cooperative arrangements of geothermal energy technology. 


\section{$2.0 \quad$ PR VI IMPLEMENTATION}

The following sections describe the activities conducted with in the three phases of the PR VI process: advanced planning, conference management, and conference evaluation and proceedings. These discussions briefly describe the activities involved in each step; the lead time required for each step; how the activities interrelate with each other; and the individual or organization with primary oversight and implementation responsibilities. Appendices $A$, $B$, and $C$ (respectively) present detailed checklists for each of these phases to assist those involved in the planning and preparation for PR VII.

\subsection{ADVANCED PLANNING}

The activities in this phase included those initiatives undertaken in the time period beginning about six months before the conference date to about one month before the conference date. The major activities conducted are addressed below. Appendix A presents a detalled checklist of all the activities required in the Advanced Planning phase.

\subsubsection{Budget and Accounting System Design and Coordination}

The DOE/GTD co-coordinator, with the assistance of its support contractor, Meridian Corporation, planned a budget to determine the anticipated expenses needed to conduct the conference. Items included in the budget were DOE and Meridian travel and per diem; estimated number of attendees; conference room rental and set-up; audio/visual equipment rental and services; refreshments; special receptions or luncheons (if any); and miscellaneous expenses such as postage and presenter badges. Based on the anticipated expenses, a registration fee was established and the collection process was defined. (The final budget is discussed later in this report.)

Once the budget was established, Meridian set up an internal master account to collect registration fees and pay expenses on behalf of DOE. The Meridian conference coordinator set up a recordkeeping system in a three-ring binder. As pre-registration forms, checks, or cancellations were received, Meridian recorded the information on a copy of the invitees 1ist, next to the respondent's name. Copies were made of all responses and filed alphabetically in a section of the binder as a cross reference. Copies of all invoices were also filed in a separate section of the binder before forwarding the invoices and checks to accounting to be deposited or deducted from the master account.

\subsubsection{Program Development}

\section{- Secure DOE Conference Approval}

The first step in this task was to prepare a "Request for Approval of DOE Sponsored Conference Under $\$ 200,000$ or 100 Attendees" form. This form includes pertinent data concerning the conference such as title, dates, DOE contact person, program justification, conference location, estimated number of attendees, draft agenda or comparable agenda from previous conference, budget, 
breakdown of services to be performed by DOE and contractor employees, and how the proceedings document is to be prepared. Once approved, the DOE/GTD Director submitted the form for approval by DOE upper management (to the Deputy Assistant Secretary level). Approval for the conference must be secured before conference planning can proceed and the form must conform to strict DOE standards. Nonconformity to format can result in the return of the form and lost planning time. The DOE/GTD co-coordinator supplied the "cover list" of names in the approval process. (Check with the DOE/GTD co-coordinator to ensure that the format has not changed from the previous year.) The approval process takes approximately one month. A copy of the "Request for Approval of DOE Sponsored Conference Under $\$ 200,000$ or 100 Attendees" form for PR VI is shown in Appendix $D$.

\section{- Develop Conference Agenda (Theme, Topics, and Presenters)}

As mentioned above, PR VI was designed to help evaluate and finalize the objectives set forth in the "Draft Statement of Programmatic Objectives" document, which was reflected in the conference theme and topics. The presentations were to address the following points:

0 The specific stated R\&D objectives in each research area.

o The probabilities of meeting the stated objectives.

- How successful completion of this R\&D is linked to the overall GTD objectives.

- The potential value of R\&D results to meet industry needs.

- The explicit strategy for transfer of research results to industry.

Meridian worked with the GTD program managers to develop a 1ist of recommended presenters and topics with the above agenda in mind. These recommendations were presented to the GTD Director and conference cocoordinators for consideration and selection. Presentation titles were chosen for the presenters in an attempt to break away from the more standardized technical presentations and to focus on the "Draft Statement of Programmatic Objectives" document.

The presenters selected were not necessarily the technical, hands-on personnel working on the specific projects; management personnel with a good overall knowledge of the technology and R\&D program were chosen when available. Presenters were asked to 1 imit their discussion of technical findings and emphasize the objectives within their program/topic area.

\section{- Develop Invitees List}

Meridian used the participant's list from Program Review $V$ and the GRC 1987 Annual Meeting attendees list as a basis for developing the PR VI invitees list. The lists were merged, updated and given to the conference cocoordinators for additions, deletions, and revisions. Once all comments were received, Meridian presented a final ist to DOE. 
- Compose and Distribute Invitees Letters

- Using the final invitees list, a letter was prepared from GTD, with assistance from Meridian. Once signed by the Director of GTD, Meridian prepared the final mailing list and mailed the letters. A pre-registration form and Participant's Fact Sheet containing logistical information was enclosed with the letter.

\section{- Invite Presenters}

The selected presenters were invited via a memo from GTD, explaining the conference theme, objectives and expectations. An updated Presenter's Handbook was enclosed with the final memo. This Handbook included:

- A checklist of deadlines for registration and submission of materials.

- Tentative program agenda (including a request for verification of the time and topic of the presentation).

- "Draft Statement of Programmatic Objectives" document.

- Guidelines for preparing camera-ready copy of papers (mat paper for the camera-ready submission was included in this mailing).

- A sample paper to be used as a model of the required format.

- Guidelines for developing effective slides.

- Participant's Fact Sheets describing logistical information.

- Program Review VI registration form.

- Hotel registration information.

- NGA Industry Round Table Announcement.

- NGA luncheon response form.

The Presenter's Handbook requested that the presenters confirm their attendance and presentation title to Meridian Corporation by a designated date. Meridian phoned all invited presenters who had not been confirmed by that date. Substitutions were then made for those unable to attend.

- Collect Biographies and Abstracts

The Presenter's Handbook also requested that confirmed presenters send Meridian a copy of their biography and a short abstract of their presentation by a designated date. Meridian phoned those who had not complied. Copies of the biographies and abstracts were given to the Director of GTD and the master was used to make copies for inclusion in the registration package to be distributed at the conference. 
- Draft DOE Memo for Executive Session Meeting

A memo was prepared from the GTD Director (two months before PR VI) inviting all DOE Headquarters and Operations office employees to attend the Executive Session Meeting following PR VI. Meridian usually documents the meeting and prepares a summary for GTD; however, the Executive Session at PR VI was informal and GTD did not require a summary.

\section{- Design and Arrange Preparation of Directional Signs}

It was decided from the layout of the hotel that four conference directional signs would be needed. Meridian's Graphics Department revised two existing signs and prepared two more with removable Velcro arrows.

\section{- Identify and Arrange Necessary Audio/Visual (AVV) Equipment and Services}

The Presenter's Handbook requested that presenters notify Meridian of $A / V$ equipment requirements. The hotel where the conference was held agreed to provide A/V services through subcontract. Meridian obtained a price 1 ist, coordinated the PR VI presenters' requirements with the NGA Round Table, and wrote the requirements into the contract with the hotel. A week before the conference, Meridian verified and amended its requirements by phone with the hotel.

\section{- Coordinate Conference Room and Seating Style}

Meridian evaluated the size and design of the meeting rooms in conjunction with the type of session, the number of expected attendees, and the amount and type of $A / V$ equipment required for each session. Meridian arranged and confirmed the room set-ups with the hotel, both in the contract and by phone, a week before the conference.

\section{- Order Conference Supplies}

About two months before the conference, Meridian provided DOE with a list of necessary supplies to be requisitioned for the registration process including folders, pens/pencils, note pads, name tags, and plastic name tag holders for 150 attendees. In addition, Meridian ordered ribbons for presenter badges.

\subsubsection{Program Promotion}

This aspect of the planning process requires significant lead time to effectively publicize and promote the conference. Program announcements and promotional materials cannot be distributed until the conference agenda is preliminarily defined. 
Under the auspices of DOE, Meridian composed and distributed an initial program announcement approximately three months before the conference to the GRC Bulletin and DOE publications DOE This Month and Energy Meetings.

(Distribution four months before the conference is desirable.) Meridian also investigated the possibility of complimentary advertisements in appropriate publications, but there was insufficient lead time to allow for publication. At least three months, four if possible, is needed. A copy of the program announcement was also sent to the DOE San Francisco Operations press office. The DOE/SAN press officer then issued a press release and made distribution to press in the San Francisco Bay area. A press release distributed by the DOE Headquarters press office should be considered for PR VII for additional publicity.

Three weeks before the conference, the final agenda layout was designed and composed. Following GTD approval, it was sent out for printing and folding. Printing was held off until the latest possible time, as last minute changes were anticipated and accommodated. Changes to the agenda al so were made the day of the conference to accommodate individual's schedules, etc. Appendix E presents the final agenda for PR VI.

\subsubsection{Pre-Registration}

Meridian was responsible for receiving, processing, and confirming preregistration responses. The monies collected were deposited into a master account set up internaliy by Meridian. The Meridian conference coordinator made copies of all payments (checks) and recorded them before forwarding the checks to accounting for deposit into the master account. (An alternative approach is to hold the checks in a secure place until after the conference for confirmation purposes and deposit. The advantage of holding the checks is that checks can be returned to "no shows" or those who are forced to cancel or make substitutions at the last minute.)

Attendees, including DOE contractors giving presentations, were charged the $\$ 45$ registration fee. DOE employees, Meridian employees, and guest presenters were exempt from paying the fee. A special "DOE registration" form was mailed to DOE employees stating that the $\$ 45$ fee was non-applicable. Guest presenters were also exempt from the registration fee and their registration forms clearly noted that the registration fee did not apply.

Meridian designed, printed and provided badges, ribbons, and other supplies necessary for registration and presentations. Approximately a week before the conference, Meridian prepared a list of pre-registrants and typed names on pre-registration badges before shipping them to conference site.

Meridian compiled registration packages for PR VI which included a preregistration participants 1ist, final agenda, Abstracts Booklet, biographies, pen, paper, city maps and tour information, and special reports applicable to the conference. Meridian then shipped these packages to the conference site. 


\subsubsection{Hotel Selection and Negotiation}

Meridian normally would be responsible for conference logistics. However, because PR VI was held in San Francisco, it was more effective for the conference co-coordinator from the DOE/SAN office to handle this responsibility. He canvassed about 20 hotels, and based on criteria determined by GTD, recommended six hotels. GTD wanted the hotel to be at an appealing, convenient location in the city, and also within the government per diem of \$95. The hotels at the airport were excluded because they were about a onehalf hour drive from downtown. Many of the downtown hotels were either too expensive or could not accommodate a conference crowd of 150.

The Travelodge at the Wharf was chosen, and the DOE/SAN conference cocoordinator was able to negotiate a $\$ 65$ lodging rate. Meridian negotiated and signed the contract with the hotel for the conference rooms and secured a block of 40 lodging rooms.

\subsubsection{Air and Ground Transportation}

The DOE/SAN conference co-coordinator was also responsible for inquiring about ground transportation and recommended shuttle services to and from the airport. He obtained information regarding the local airports, taxi shuttle, the subway, and bus services. Meridian incorporated his recommendations into the Participant's Fact Sheet.

\subsection{CONFERENCE MANAGEMENT}

This phase involved the activities conducted immediately prior to and during PR VI to conduct and facilitate the actual conference, including on-site activities.

\subsubsection{Final Agenda}

As discussed previous1y, the agenda underwent numerous revisions, even during the actual conference. Appendix E presents the final agenda for Program Review VI.

\subsubsection{Einal Invitees List}

of the 496 people invited to attend PR VI, 127 attended. This was the largest attendance since PR III, held in El Centro, California in 1984. Program Review III attracted 207 attendees in the "hey-day" of geothermal interest. All other Program Reviews were held in Washington, D.C. with an average attendance of 90 participants. The invitees 1 ist is on file at Meridian for use in PR VII planning. 


\subsubsection{On-Site Inspection of Hotel Facilities/Services}

Once at the site, the Meridian conference coordinator confirmed and evaluated all logistical/facilities arrangements. Meridian oversaw the set-up and inspection of the audio/visual equipment, and operation of the equipment and lights during the conference. Meridian also posted directional signs and ensured the conference announcement was placed on the hotel directory.

\subsubsection{On-Site Registration}

Meridian obtained and supplied a typewriter, ribbons, and other supplies necessary for on-site registration. Meridian provided one person to oversee the registration process and was assisted by the DOE/SAN co-coordinator. At least one additional person would have been helpful for the first day, as there were many walk-ins. Meridian also prepared a list of on-site registrants for use in preparing a final list of attendees.

\subsubsection{Conference Facilitation}

During the conference, Meridian conducted registration, monitored the projection equipment and lighting, coordinated the room set-ups and breaks with the hotel management, took photos of the presenters and audience, took phone and facsimile messages, and attended to conference attendees' and presenters' needs and questions. After the conference, Meridian packed and shipped remaining supplies, reports, and directional signs to their offices.

\subsubsection{Post Conference Wrap-up}

Immediately after the conference, thank you letters were prepared from the GTD Director to presenters and special guests. Meridian arranged for payment of the master account invoices and closing out the master account. Meridian al so followed up with requests for outstanding registration fees to two participants.

GTD should consider submitting a post-conference article (and a conference picture) for publication in DOE This Month and other trade publications not covered by the press.

\subsection{CONFERENCE EVALUATION AND PROCEEDINGS}

The activities performed in this phase occurred during and immediately following the conference and included activities conducted to receive and compile the participants' evaluation inputs and to prepare and publish conference proceedings. 


\subsubsection{Conference Evaluation}

Following PR VI an evaluation form was prepared and mailed under a DOE cover memo to all conference attendees. The form requested feedback regarding how the various elements and provisions of the conference were perceived and what changes need to be made for future geothermal program reviews. The results of these evaluations are summarized in Chapter 4 of this report, with resulting recommendations for PR VII.

\subsubsection{Proceedings Preparation}

Meridian designed the cover for the proceedings document and collected camera-ready copies of the presentations. Meridian edited and revised those papers that did not comply with specified standards. Meridian assisted GTD in preparing an introduction from the GTD Director, a final agenda, and final participants ifst. Once all materials were gathered, Meridian compiled and numbered the pages, then delivered the proceedings to GTD for approval and publishing. The DOE/GTD conference co-coordinator handled publication information (NTIS number and price) and arranged for publishing through DOE. Actual publishing took approximately four weeks. Meridian distributed copies of the proceedings to conference attendees and others who expressed an interest. 


\subsection{MANAGEMENT ORGANIZATION AND RESPONSIBILITIES}

Exhibit 1 shows the management and organizational structure for the activities leading to the development and implementation of the "Program Review VI: Beyond Goals and Objectives" conference.

As indicated, the Director of the U.S. GTD had the lead responsibility for conference activities and served as conference chairman. He was assisted by co-coordinators from GTD and the DOE San Francisco Operations office. The cocoordinator from DOE/GTD served as the focal point for overall planning and conference management. The co-coordinator from DOE/SAN assisted him in the planning and preparation and implementation of the conference and for coordination of conference logistics. Meridian Corporation served as conference coordination support. In this capacity Meridian was responsible for assisting the co-coordinators with all aspects of planning and implementing the conference activities. The geothermal managers from the DOE Operations offices in Idaho and Albuquerque coordinated presentations and chaired Sessions Two through Five on the geothermal technologies. The DOE/GTD CO-coordinator chaired Session Six, "Special Issues."

The advanced planning phase required the time and expertise of the Director of GTD and cO-coordinators from DOE/GTD and DOE/SAN and contract hours from Meridian. The Director of GTO was responsible for overall coordination of the conference and all activities and decisions were approved by him. The DOE/GTD co-coordinator was responsible for day-to-day management of the planning activities. The DOE/SAN co-coordinator spent many hours calling and visiting hotels in order to find a place amenable to PR VI's needs. He handled the logistics of the conference, Including transportation, pre-negotiations, and recommendations. In addition, many hours were spent planning and designing the program, handling pre-registration (developing and mailing information, collecting and recording checks, etc.), and negotiating and ensuring services and set-up with the hotel.

The actual conference management was handled by the same people. The Meridian conference coordinator and the DOE/SAN co-coordinator handled the registration process. The Meridian coordinator was responsible for the overall conference facilitation. Meridian staff was responsible for 1 ighting and audio/visual equipment during the conference. The Meridian Geothermal Task Manager provided on-site assistance as well. The Meridian conference coordinator and DOE/GTD co-coordinator were primarily responsible for preparing conference evaluation and proceedings.

\subsection{RESOURCE REQUIREMENTS}

The actual budget is shown in Exhibit 2. As indicated, there were 95 paying attendees. The amount collected in registration fees was $\$ 4,275$ (including two outstanding billings). Expenses incurred for hotel facilities and set-up fees, audio/visual rental and set-up fees, and miscellaneous costs for items such as supplies, reproduction and shipping amounted to $\$ 3,971$. 
EXFIBIT 1

CONFERENCE MANAGEMENT TEAM ORGANIZATION

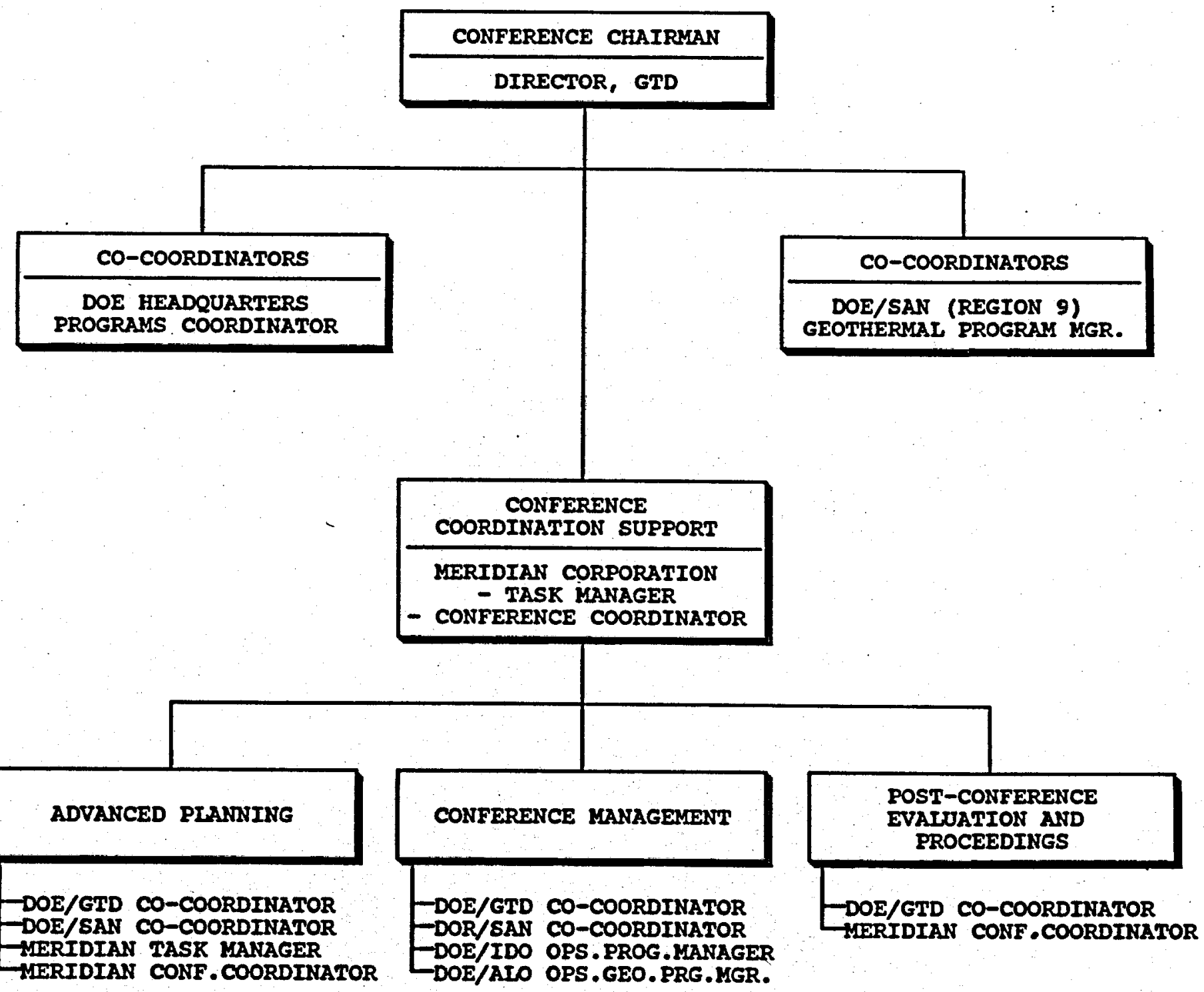




\section{Exhibit 2}

PR VI CONFERENCE BUDGET

DOE/CE employee travel and per diem Other DOE employee travel and per diem Support contractor travel and per diem
$\$ 7,000 *$

$3,000 *$

$3.000 *$

Total DOE and Support Contractor Travel Expenses

$\$ 16,000 *$

Hotel facilities and set-up fees

$\$ 2,514$

Audio/visual rental and set-up fees

1,135

Reproduction, shipping, and miscellaneous

322

Total Miscellaneous Expenses

\$ 3,971

Registration fee (per person)

$\$ 45$

Total Paying Registrants

$\underline{95}$

Total amount collected from registration fees

\$ $4,275^{* *}$

* Estimated

$* \star$ Including $\$ 90$ to be received. 


\subsection{EVALUATION OF PR VI}

Meridian developed and distributed an evaluation form to request feedback from participants regarding the various aspects of the conference that will assist GTD in planning PR VII. Appendix F provides actual responses received. The evaluation form addressed four areas: conference evaluation, meeting room evaluation, facility evaluation, and comments/suggestions. Choices of ratings were "good," "fair," and "poor." The following sections summarize the evaluation comments and present resulting recommendations for PR VII.

\subsection{EVALUATION OF PR VI PROCESS}

Overall, the conference was deemed a success. The San Francisco location drew more representation from industry than previous reviews (with the exception EI Centro) and industry was generally pleased with DOE's attempt to increase their involvement. The National Geothermal Association Round Table helped attract industry representatives and enhanced the exchange of information. In general, attendees felt that the overall conference organization was good and that everything was well-planned and executed. However, suggestions and comments were provided for improving various aspects of the process for PR VII.

Meridian received 49 evaluation responses from a total mailing of 116. Generally, the responses were favorable. An industry spokesman wrote that he felt there was a wealth of information presented at the program and that the informal atmosphere provided an opportunity for many worthwhile discussions, both during the program and after hours.

Everyone seemed to enjoy the addition of the NGA Round Table to the Program Review VI schedule. Attendees and Round Table members interacted in a lively question-and-answer exchange which drew many interesting viewpoints. Several respondents commented that the Round Table should have been scheduled closer to the beginning of the conference.

The comments revealed that even more industry participation was desirable. One respondent from industry suggested that future reviews should expand industry's participation to help identify how the research data are being used to develop new tools and materials for geothermal utilization, such as mud producers, tool manufacturers, and materials producers. He also felt it would be helpfui to discuss the effectiveness and verification of geo-reservoir modeling as it relates to producing reservoirs.

Responses were mixed as to whether new technologies were adequately described." Some respondents felt that presentations were simply a "rehash" of past Program Reviews and that many of the presenters had little knowledge of or interest in the materials they were presenting. A few respondents commented that they did not get a clear understanding of how the various technologies were going to meet their cost objectives. Also, it was felt that some presentations did not sufficiently focus on the conference theme or the "Draft Statement of Programmatic objectives" document. Requests were also made for more discussion on drilling, direct heat applications, non-electric use of geothermal energy, and environmental work. 
One industry representative said he did not see many new programs and that most presentations were of ongoing work started in the late 1970's and early 1980 's. He suggested "a new scoping of work (contractors/labs) is needed and some of the old projects which are 'spinning their wheels' should be terminated." He al so commented that he felt most of the attendees were government contractors who "talked mainly among themselves," and he did not feel the purpose of obtaining outside comments or programs was achieved.

State and local concerns felt the conference was too dominated by national laboratories, resulting in an inadequate debate on major programmatic issues. Three respondents suggested that GTD include summaries of the accomplishments of state-U.S. DOE cooperative studies.

Nearly all respondents praised DOE for choosing the San Francisco location for the conference and expressed a desire to hold future conferences at other west coast locations. Many responses, however, were critical of the hotel and conference facilities. It was generally felt that the conference room was too small, lacked proper ventilation, had poor lighting, and was inaccessible to the hotel lobby except by going outdoors (in the rain).

DOE also received "high marks" for allowing more time after PR VI presentations for questions from the floor. Nearly all respondents felt the time allotted was adequate; only a few respondents felt more time should be allowed for Q\&A's at PR VII.

Comments were somewhat critical of the audio/visual materials used during the presentations. A/V materials averaged, at best, a "fair" rating with several complaints that some overheads were hard to read and that sildes, view graphs, and other visual aids were often of poor quality and too complicated for this type of audience. Suggestions were also made for using a larger screen, a riser, and additional tables for $A / V$ equipment and materials.

Earlier notification of the next conference and coordination of scheduling with the DOE Enhanced 011 Recovery Conference was also requested.

\subsection{RECOMMENDATIONS FOR PR VII PLANNING}

Based on inputs from the evaluations, DOE, and contractor staff, several recommendations are provided below for facilitating PR VII:

\section{Program Planning and Development}

- Planning and preparation for PR VII should begin in August-September 1988.

- Continue to emphasize industry participation. Schedule their time slot early in the program.

- Due to the favorable overall response from attendees, it is recommended that another west coast location, such as Oregon, Nevada or New Mexico, be chosen. 
Consider having two different types of meetings:

- A project-by-project review of research at the bench level, presented by the principal investigators to HQ and Operations Office project/program managers and the Division Director with relevant detailed discussion of research performed during report period only, and budget issues. This should be held every six months in Washington, D.C., with no outside attendees.

- A program-by-program review, with one presentation per program shared by the HQ program manager and the manager from the national lab or industry contractor responsible for the program. This should not be a detailed discussion of research at the project level, but a look at goals/objectives, potential economic benefits, parameters and status. Attendance would be from other pertinent federal and state government agencies, and industry. This should be held once each year, with the location to be selected from cities in areas that are currently or are expected to be involved in geothermal development.

- Expand invitees list to include suppliers such as drillers, loggers, etc.

- Depending on the nature of the conference, choose management-type presenters rather than technical persons; technical persons can be in the audience to answer specific technical questions.

- Maintain closer oversight of preparation of presentations and attention to details of visuals aids.

- Collect presentation papers two months ahead, compile and publish proceedings, and distribute them at the conference.

- Distribute announcements of the meeting at least three months in advance. Invite presenters five months in advance and insist papers be submitted three months before conference to allow for printed proceedings to be distributed at the conference.

- Send out a DOE press release two to three months in advance and advertise in energy trade publications and journals.

\section{Logistics}

- Choose a larger conference room with tables (as well as chairs) for participants.

- Refreshments should be set up in the conference room or immediately outside the conference room, rather than in another building.

- Consider obtaining a larger screen for the $A / V$ equipment and a riser for the presenter, and provide a flashlight pointer. 
- Send a summary articie and a picture to DOE This Month and the GRC Bulletin immediately following the conference.

- Consider having a no-host icebreaker the night before the conference. 


\subsection{PROPOSED SCHEDULE FOR PR VII PLANNING PROCESS}

The planning process should be initiated in August/September 1988, to ensure a high quality PR VII program. Exhibit 3 presents a Proposed Schedule for PR VII. The schedule shows recommended start times for critical activities. 
Exhibit 3

PROPOSED SCHEDULE FOR PR VII

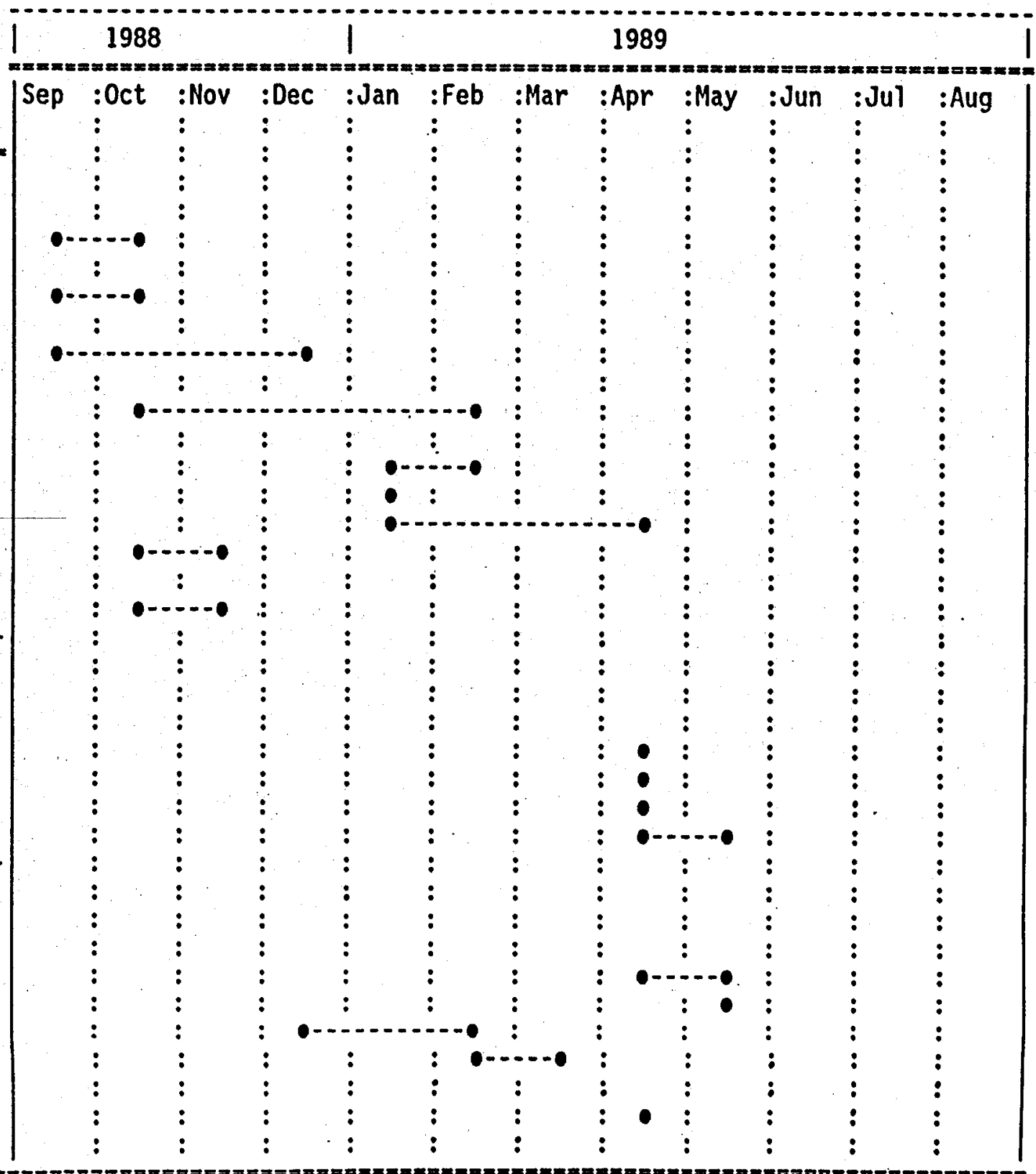


APPENDIX A

ADVANCED PLANNING CHECKLIST

A-1 
ADVANCED PLANNING CHECKLIST

1. Establish Budget and Accounting System

- Develop budget

- Determine registration fee and collection process

- Set-up Accounts and Recordkeeping System

- Meeting room assignments and scheduling

- Pre-registration

- On-site registration

- Audio/visual equipment and services

- Hotel/refreshments

2. Program Development

- Prepare and process "Request for Conference Approval" form

- Identify and develop special conference documents/reports

- Prepare preliminary agenda

- Prepare draft list of all invitees

- Prepare Participant's Fact Sheet

- Compose and distribute letter to potential speakers and confirm participation, details of accommodations, honoraria and transportation

- Prepare and distribute Presenter's Handbook discussing presentation content, time allotment, suggestions for preparing good slides and camera-ready copy of papers for proceedings. Prepare schedule and design format for submission of copies of presentation for proceedings

- Request and collect biographies from speakers

- Collect and complle Abstracts Booklet for registration packages.

- Design and arrange for preparation of directional signs

- Compose and distribute letters of invitation to targeted attendees 
- Identify necessary audio/visual equipment or services needed to conduct conference sessions; obtain price lists; and select vendor

- Determine and coordinate room seating style and layout for each session

- Request DOE requisition of folders, pens, notepads, name tags, plastic name tag holders and mats

- Order ribbons for speaker badges

- Prepare and distribute special materials/documents to conference participants in advance

- Draft DOE internal memo inviting all DOE personnel to attend Executive Session meeting following the conference

3. Program Promotion

- Compose and distribute initial program announcement of conference to all affiliated trade publications

- Arrange for complimentary advertisements in appropriate publications

- Compose draft press releases, provide photos and other promotional details and have DOE distribute to appropriate media

- Design, compose, and print final program

4. Pre-Registration

- Receive, process, report and confirm pre-registration response

- Design, print, and provide badges, ribbons, and other supplies necessary for registration

- Print names of pre-registrants on badges

- Prepare detailed instructions for on-site registration processing

- Design, compose, print, and ship list of pre-registrants for distribution with program materlals/registration package to all registrants

- Compile registration package with agenda, paper, pen, Abstracts Booklet, list of participants, city maps, tour information, etc.

- Ship registration packages to conference site

5. Hotel Selection and Negotiations

- Determine conference facilities/lodging requirements for conference and DOE Executive Session in coordination with other activities (i.e., NGA Industry Round Table) 
- Canvas 15-20 area hotels or meeting facilities

- Provide hotel properties with requirements for sleeping rooms, suites, meeting rooms, food and beverage functions

- Evaluate ratio of total number of sleeping rooms and meeting rooms to DOE conference needs and those of other related activities (i.e., NGA Round Table)

- Determine availability of support services such as secretarial services, banking services, $A / V$ equipment, and support staff

- Determine day-of-week schedule most appropriate for conference needs

- Determine reservation process for attendees and organizers

- Conduct on-site inspection tour

- Negotiate lowest possible group rates for hotel and meeting rooms

- Negotiate most flexible room reservation policies and arrival departure schedules

- Choose 3-5 hotels for recommendation to GTD based on price, location availability, meeting space and amenities

- Reach Agreement of Contract performance, delivery terms, and cancellation policy

- Negotiate complimentary accommodations or amenities

- Obtain hotel brochures, complimentary reservation cards, maps, and transportation information availability of hotel or pubiic shuttle service to the airport and cost; parking facilities and cost; local sight-seeing information

- Reach Agreement on credit arrangements, billing procedures and reporting

- Select hotel and have contractor sign contract with hotel for conference rooms (Secure block of rooms for participants and request compl imentary hotel registration)

6. Air and Ground Transportation Selection and Negotiations

- Evaluate traffic flow patterns and accessibility to other areas or facilities of the hotel and privacy from other groups and disturbance, e.g. construction, traffic congestion, etc.

- Evaluate air services and schedules for DOE Headquarters and Operations offices personnel and contractor personnel 
- Determine availability of schedules and fares, car rental, bus and subway, and airport shuttle services from airport to meeting facilities and within surrounding area

- Determine lowest possible rates for air and ground transportation and make recommendations 


\section{APPENDIX B}

\section{CONFERENCE MANAGEMENT CHECKLIST}




\section{CONFERENCE MANAGEMENT CHECKLIST}

1. On-Site Inspection of Hotel Facilities/Services

- Confirm and evaluate on-site logistical/facilities arrangements

- Coordinate set-up and inspection of $A / V$ equipment

- Assign person(s) to operate A/V equipment and lights

- Post signs, etc.

2. On-Site Registration

- Make sure the registration area is easy to locate

- Set aside a clearly marked area for registrants to complete forms

- Supply or obtain typewriter, ribbons, telephone and message board, and other supplies necessary to fulfill on-site registration

- Know where pay phones, restrooms, copy facilities, restaurants, message center, parking facilities, emergency services and shopping areas are located

- Provide volunteers or other personnel to process on-site registration. Registration area should be staffed at all times, but only fully staffed during peak hours

- Design, compose and print list of on-site registration for postconference distribution

- Have at least $\$ 200$ on hand to give as change for cash payments

- Designate one person as cashier to handle billing and checks/cash payments. Have receipts that can be completed quickly

- During registration lulls, file registration forms

- Assign on-site personnel to monitor room conditions during the conference and to interface with facility management and engineers

- Ship left over supplies, reports, directional signs, etc. back to contractor facility 
3. Conference Facilitation

- Monitor projection equipment

- Coordinate message board

- Coordinate with hotel management and oversee refreshment breaks, room set-ups, etc.

- Take photographs of speakers and audience

- Attend to conference attendees' questions and problems

- Receive evaluation forms

4. Post-Conference Wrap-Up

- Draft thank-you letters to speakers

- Arrange payment of Master Account

- Write article (and enclose conference picture) for publication in DOE This Month (internal newspaper) and other trade publications not covered by press

- Draft summary of DOE Executive Session meeting (if requested) 


\section{APPENDIX C}

CONFERENCE EVALUATION AND PROCEEDINGS CHECKLIST

$C-1$ 
1. Conference Evaluation

- Draft evaluation form for DOE approval

- Distribute to conference attendees (at conference)

- Compile responses and summarize into a post-conference report for DOE

2. Proceedings Activities

- Design cover for proceedings

- Collect camera-ready coples of presentations (prior to conference)

- Edit and revise those which do not comply to specified standards

- Prepare final agenda

- Prepare final participants list

- Draft introduction and have it approved and signed by the DOE GTD Division Director

- Compile and number pages

- Deliver to DOE for approval and publishing

- Distribute proceedings to conference attendees and others expressing an interest 


\section{APPENDIX D}

REQUEST FOR APPROVAL OF DOE SPONSORED CONFERENCE UNDER $\$ 200,000$ OR 100 ATTENDEES 
REQUEST FOR APPROVAL OF DOE SPONSORED CONFERENCE UNDER $\$ 200,000$ OR 100 ATTENDEES

Conference Titie:

DOE Geothermal Program Review VI

Dates:

April 12-14, 1988

Location:

San Francisco, California

Program Office Contact/Phone:

Ralph Burr (586-5335)

Program Office Director:

\section{Date:}

A. Butler
L.I. Nelson
K.G. Moore
R.L. San Martin
G. Geisick
R.L. Dwyer


REQUEST FOR APPROVAL OF DOE-SPONSORED CONFERENCE

UNDER $\$ 200,000$ OR 100 ATTENDEES

1. Conference Title:

DOE Geothermal Program Review VI

2. Conference Dates:

Apri1 12-14, 1988

3. Name of Co-sponsors (both Federal and Non-Federal):

None

4. CE Program Contact (with phone number):

Ralph Burr (586-5335)

5. Program Supported:

DOE Geothermal Technology R\&D Program (Conference covers all program elements.)

Justification of why the conference is essential to mission of the program; benefits to be derived; alternative means available for achieving the same results.

The annual program review meetings are an important element in the Geothermal Technology Division's effort to develop, refine and expand the technology base needed for utilization of the Nation's vast geothermal resources. The meeting's focus is to review and explore exciusively the DOE's Geothermal R\&D Program. Through the participation of DOE/Headquarters, Operations Offices, National Laboratories, contractor personnel and the private sector, the meeting fosters and promotes a technical information exchange. A strong emphasis this year will be industry's involvement in the program review and the DOE Geothermal R\&D program in general. A greater level of industry participation would heighten both private sector and government sector awareness of the technojogy transfer opportunities avaflable. 
6. Location of the Conference:

San Francisco, California

Justification for selection, including an analysis of alternatives considered and reasons for selection of iisted site:

Since the DOE Geothermal R\&D Program Review meeting has been held in Washington, D.C. for the past two years, industry participation has been reduced due to the remoteness of Washington, D.C. from the center of the U.S. geothermal industry base in the western states and travel budget 1 imitations. The selection of a San Francisco, California conference location would put the conference in a centralized location close to geothermal development and consequentiy close to the operators, suppliers and developers of geothermal energy who might thereby be induced to attend in 1 arger numbers.

7. Agenda:

Attach a copy of the agenda, including clearly stated lecture or discussion titles, names and titles of speakers, and any other background that you believe is pertinent. If agenda is not yet final, attach draft or outline with as much explanation as possible.

Agenda from previous meeting is attached. While specific topics will vary, this year's agenda will have the same comprehensive coverage of the DOE Geothermal R\&D program, with an additional one-half day session devoted to informing and exploring with the U.S. industry the technology transfer opportunities that are available and the vehicles through which the industry can access these opportunities. A draft agenda will be provided when avallable.

8. Total Estimated Number of Attendees: 125

CE employees:

Other DOE employees (specify organizations):

- Albuquerque Operations office:

-San Francisco Operations Office:

-Idaho Operations Office:

Contractor:

-Laboratories

- Private

Other Federal employees: (USGS, BLM, Forest Service)

State and local government employees: 10

Private sector representatives: 
9. Breakdown of Total Co-sponsors Support (both Federal \& Mon-Federal): Not applicable.

Breakdown of Total DOE Costs:

Cost Categories

Amount

Paid By*

CE employee travel \& per diem:

Other DOE employee travel \& per diem:

\$ 4,600

4,800

CE

Estimated other Federal employee

travel \& per diem:

DOE contractor travel \& per diem:

1,000

11,000

Other DOE

Other

CE

Conference logistics:

- Hotel facility rental fees:

- Meeting room arrangements:

-Other (specify):

0 -

-0 -

$-0-$

Technical support and presentations:

Honoraria:

Travel costs for invited speakers:

Reporting of conference events and results:

- Preparation (program proceedings):

- Individual attendees copies:

Supplies and support equipment:

Audio visuals \& supplies:

Direct labor support and overhead:

-Logistical support:

-Overhead (7.75\%)

$\$ 1,800$

Other costs:

140

-0 -

-0 .

-0 -

250

2,000

Contractor

CE

1,000

Contractor

Total of above costs:

$-C E$

- Other DOE

- Contractor

-Other

1,940

$-0-$

$\$ 26,590$

$\$ 17,600$
4,800
3,190
1,000

* CE, Other DOE, Contractor, Registration Fee, Other

Cost per person (divide total cost of conference by number of attendees not including DOE): \$248.50

10. How were proposed DOE attendance and/or logistical costs reduced:

The San Francisco Bay area is the most cost effective location when overail DOE travel costs are considered and maximum industry attendence is desired. 
11. Termination costs for other sponsors which would result from disapproval of this request:

Not applicable.

Termination Costs for DOE:

None.

12. Name of contractor or grantee and type of instrument (e.g., cost plus fixed fee contract, 8A contractor, etc.) under which services are to be performed:

Meridian Corporation will provide services with respect to this conference. These services will be provided under Meridian Corporation's existing support contract number DE-ACO1-86CE-30844. This is a costplus-fixed-fee contract.

13. Identify separately those tasks being performed by DOE employees and by contractor employees:

Meridian Corporation will assist with conference logistics, preparation of the conference agenda and speaker notifications. Meridian will also take notes and prepare a summary of the DOE geothermal R\&D planning meeting (for DOE employees only) which accompanies Program Review VI, and will collate and assemble the papers and other proceedings materials supplied by DOE. Meridian will also prepare suitable visual aids required for Headquarters technical presentations at Program Review VI.

DOE personnel will perform all other tasks associated with Program Review VI logistics and planning, including speaker identification, structure of topical sessions, preparation of invitations and notices, assistance with visual aids during speaker presentations, and production and distribution of the proceedings. DOE San Francisco Operations office would be given primary responsibility for the principal logistics associated with the geothermal program review.

14. Type of report that will be prepared to document conference proceedings:

Each speaker will supply a camera-ready copy of his/her presentation prepared as a technical paper on standard DOE mats. The presentation will be assembied in session/topical order, indexed and bound into a proceedings document with suitable introduction materials. Proceedings will be distributed free to attendees and will be available to other interested parties through the National Technical Information Service at NTIS's price. 
15. When was the last time a meeting of this nature was held?

April 14-15, 1987

a. Sponsors:

DOE

b. Summary of projected vs. actual costs:

Projected Actual
Costs PRV Costs PRV*

$\$ 3,000$

$$
8,000
$$

650

722

150

11

$\$ 12,533$ travel costs for DOE employees

(Ops Office personnel) DOE contractor travel costs

(15 contractors total - 10 at $\$ 600$ each; 5 at $\$ 400$ each)

support contractor direct labor cost

support contractor burden (103\%) and percentage (7.75\%) on labor support contractor provided supplies and equipment support percentage (7.75\%) on supplies and equipment provided

total costs to CE

- Actual costs for Program Review $V$ were approximately the same as projected.

16. Are there plans for related, similar, or follow-up meetings (either Government or private sector)? If so, list and give expected dates and purposes.

Yes. The meetings are held annually. The next one is expected to be held in April 1989 in Washington, D.C. The purpose of the meeting will be the same. 
DOE Ceotheraal Program Review V

Aprif 24-15, 1987

The Forrestal Bullding

Uashington, D.C.

AGENDA

at All sessfons will be held in Roon IE245 wt

Iuesdav. April 14. 1987

8:00 Registration begins

Cheiroerson: John E. Mock, Director, Geothermal Technology Division U.S. Department of Energy

9:05 Introductions

9:05 Meicoming Remarks \& Keynote Address

9:30 DOE Geothermal Program Overview

10:00 Status of U.S. Geothermal Industry

10:30 COFFEE BREAK

10:15. The Year that was for Office of Basic Energy Setences/ Geosetences

11:10 International Agreements

11:20 UN Geotheran Initiative

11:45 LUNCH BREAK
John E. Mock

Robert L. San Martin

Deputy Assistant Secretary for Renewable Energy

John E. Mock

David Anderson

Geothermal Resources Councit

George A. Kolstad

Office of Energy Research

U.S. Department of Energy

Marshall Reed

Geothermal Technology Division U.S. Department of Energy

Mikkl Beredjick

Director, liatural Resources and Energy Division

United Mations 
Ivesdav.Aprt1 14. 1987 (cont.)

5:30 COCKTAIL RECEPTION

(Cash Bar)

Holiday Inn-Capifol

Kednesdar. Aorsl 15, 1987

Cheiperson: Carlos Garcla, Albuquerque Operations office (ALO)

U.S. Department of Energy

8:00 AlO Geothermal Program Overview

8:10 Hard Rock Penetration Overview

8:20 Research in Lost Circulation Control for itothermal Wellis

8:35 Coring Deep Into Hard Rock Formations

8:50 A Prototype Radar Fracture Mapping System

9:05 Magma Energy Extraction Overview

9:20 Recent Progress in Hagma Energy Extraction

9:35 Ceothermal Drilling Organization

9:50 COFFEE BREAK

10:05 Hot Dry Rock Programatic Highlights

10:25 Operations and flow Testing at Fenton HIII

10:55 A Mex Method for Determining Dominant Fiuid fiow Paths During Hydraulte Fracturing

11:10 Tracking Thermal Fronts with Temperature-Sensitive Chemically Reactive Tracers

11:25 That is Required to Make cood Measurements in a Geotheral Clellbore?
George P. Tennyson

Albuquerque Operations office

James C. Dunn

Sandia Mational Laboratory

Alfonso Ortega

Sandis licitonal Laboratory

Douglas S. Drumheller

Sandia Natsonal Laboratory

Hsi-tien Chang

Sandfa National Laboratory

James C. Dunn

Sandia National Laboraiory

Alfonso Ortega

Sindia Mational Laboratory

James C. Dunn

Sandia National Laboratory

Hugh D. Murphy

Los Alamos National Laboratory

Robert H. Hendron

Los Alamos Katfonal Laboratory

Michuel C. Fehler

Los Alamos National Laboratory

Bruce A. Robinson

Los Aíanos National Laboratory

Bert R. Dennis

Los Alanos National Laboratory 
Yednesday. Aoril 15, 1989 (cont.)

\section{RESERVOIR TECHNOLOGY}

$3: 20$

Hell Test, Bench-Scale Experinent. a Field Application

3:40 Reservoir Technology Research at LBL

4:00 Pre-drilling Data Review and Synthesis Long Valley, California

4:15 Fracture Definition: Formation Preservation, Delineation

4:30 Seismic Imaging, Medicine Lake Caldera

4:50 Closing Remarks
Henry J. Ramey Stanford University

Marce io J. LIppoman Lawrence Berkeley Laboratory

Norman E. Goidstein Lamrence Berkeley Laboratory

Dennis L. Mielson University of Utah Research Institute

Paul H. Kasameyer Laurence Livermore Natic:-: Laboratory

Ronald R. Loose

Oirector of Renewable Energy Technologies 


\section{APPENDIX E}

FINAL AGENDA FOR "PROGRAM REVIEW VI: BEYOND GOALS AND OBJECTIVES"

$E-1$ 
U.S. Department of Energy Geothermal Program Review VI

"Beyond Goals and Objectives"

\author{
April 19-21, 1988 \\ Travelodge at the tharf \\ San Francisco, CA \\ AGENDA
}

April 19. Tuesday

\title{
SESSION I
}

Overview:

8:00 Registration

9:00 Greeting

John E. "Ted" Mock, Director, Geothermal Technology Division, U.S. Department of Energy, Washington, D.C.

9:05 Helcome

Thomas Heenan, Assistant Manager, Energy Programs, San Francisco Operations Office, U.S. Department of Energy

9:15 Opening Remarks - Renewable Energy Contribution to the National Energy Future

Robert San Martin, Deputy Assistant Secretary, Renewable Energy, U.S. Department of Energy, Mashington, D.C.

9:30 Keynote Address - Industry

Perspective on the Federal Geothermal James B. Combs, President, Geothermal R\&D Program

Resources International, Inc.

10:00 Coffee Break

10:30 Introduction to Theme - Beyond coals and objectives

John E. "Ted" Mock, Director, Geothermal Technoiogy Division, U.S. Department of Energy

11:00 Regional Aspects of Geothermal Energy Development

Martha Dixon, Director, Conservation and Renewable Energy Division, San Francisco Operations Office, U.S. Department of Energy

11:30 Lunch (no host) 
Hydrotheralal Research Progran Objectives:

Chairperson: Susan Prestwich, Geothermal Program Manager, Idaho Operations Office, U.S. Department of Energy

1:10 Increasing Reservoir Confirmation and Well Siting Confidence through Hydrothermal Earth Science Research

1:40 Reducing Long-Term Reservoir Performance Uncertainty

2:10 Understanding Geothermal Reservoir Dynamics

2:40 Geophysical Measurement of Geothermal Fluid Production and Injection

3:10 Coffee Break

3:30 Optimizing Reservoir Management through Fracture Modeling

4:00 Decreasing Energy Conversion Costs with Advanced Materials

4:30 Biological Solutions to Waste Management

5:00 The Prediction of Chemical Sealing in Geothermal Power Operations

$5: 30$ : Adjourn
Dennis L. Nielson and Phillip M. Wright, University of Utah Research Institute

\author{
Marcelo Lippmann, Lawrence Berkeley \\ Laboratory \\ Roland Horne, Stanford University \\ Paul Kasameyer, Lawrence Livermore National \\ Laboratory \\ Joel Renner, Idaho National Engineering \\ Laboratory \\ Lawrence Kukacka, Brookhaven National \\ Laboratory \\ Eugene Premuzic, Brookhaven National \\ Laboratory \\ John Weare, University of California at San \\ Diego
}

April 20, Wednesday

\section{SESSION II (Continued)}

Hydrothernal Research Progran Objectives:

Chairperson: Susan Prestwich, Geothermal Program Manager, Idaho Operations Office, U.S. Department of Energy

8:30 Monitoring the Materials and Chemistry of a Geothermal Plant

Donald Shannon, Pacific Northwest Laboratory

9:00 Improving the Efficiency of Binary Cycles

Gregory Mines, Idaho National Engineering Laboratory

9:30 Reducing Drilling and Completion James Dunn, Sandia National Laboratories

Costs -. Hard Rock Penetration Research

10:00 Coffee Break 
Geopressured-Geotherial Research Program Objectives:

Chairperson: Susan Prestwich, Geothermal Program Manager, Idaho Operations Office, U.S. Department of Energy

$10: 20$

Research to Understand and Predict Geopressured Reservoir Characteristics with Confidence

10:50 Potential for Utilizing the Geopressured-Geothermal Resource

11:20 DOE/EPRI Hybrid Power System

11:50 Lunch (no host)
Susan Stiger, Idaho National Engineering Laboratory

C.R. Featherston, Eaton Operating Co., Inc.

Susan Stiger, Idaho National Engineering Laboratory

\section{SESSION IV}

Hot Dry Rock Research Program Objectives:

Chairoerson: George P. Tennyson, Jr., Program Manager, Geotherma1, Wind Energy and Superconduct ivity Programs, Albuquerque Operations Office, U.S. Department of Energy

1:10 Hot Dry Rock Fracture Propagation and Reservoir Characterization

1:40 Prospects for Hot Dry Rock in the Future

2:10 Drilling and Completion at Fenton Hill

2:40 Hot Dry Rock Venture Risks Assessment
Hugh Murphy, Los Alamos National Laboratory

Nichael Berger, Los Alamos National Laboratory

Hugh Murphy, Los Alamos National Laboratory

Frank Cockrane, Bechtel National, Inc.

3:10 Coffee Break

\section{SESSION $V$}

Maqma Energy Research Program Obfectives:

Chairperson: George P. Tennyson, Jr., Program Manager, Geothermal, Wind Energy and Superconductivity Programs, Albuquerque Operations Office, U.S. Department of Energy.

\section{3:30 Research to Tap the Crustal Magma Source}

$4: 00$

Recent Advances in Magma Energy Extraction

4:30 Drilling Program for Long Valley Caldera

5:00 Adjourn

5:00 DOE/GTO Management Review (Executive Session)
James Dunn, Sandia Mational Laboratories

T.Y. Chu, Sandia Mational Laboratories

John Finger, Sandia National Laboratories 
(The National Geothermal Association will hold an Industry Round Table Discussion in the same hote1. Program Review VI registrants are invited to attend and participate.)

\section{Apri) 21, Thursday}

8:30 National Geothermal Association Program Lanier Lohn, President

8:45 Round Table Discussion on Government/Industry Partnership: Perspectives and Cooperation Coffee Break (as time permits)

12:00 NGA-Sponsored Luncheon: Commissioner Barbara Crowley, California Energy Commission

\section{SESSION VI}

\section{Special Issues:}

Moderator: Ralph Burr, Geothermal Technology Division, U.S. Department of Energy, Washington, D.C.

2:00 Quantifying the Cost-of-Power Impacts of Federal Geothermal R\&D

2:20 Government/Industry Cooperative Agreements -- National Academy of Sciences Recommendations

2:40 Government-Industry Cooperation at Work: Example of the Geothermal Driliting Organization

3:00 International Market Opportunities for Geothermal Companies

3:20 Question and Answer Period

4:00 Closing Remarks

4:15 Adjournment
Richard Traeger, Sandia National Laboratories, and Daniel Entingh, Meridian Corporation, Alexandria, Virginia

John E. Mock, Director, Geothermal Technology Division, U.S. Department of Energy, Washington, D.C.

James Dunn, Sandia National Laboratories

Linda Joy DeBoard, Energy Technology Export Program, California Energy Commission

Ronald Loose, Director, Office of Renewabie Energy Technologies, U.S. Department of Energy, Hashington, D.C. 
APPENDIX F.

CONFERENCE EVALUATION RESPONSES

F-1 


\begin{tabular}{|c|c|c|c|c|c|c|c|c|c|}
\hline \multicolumn{4}{|l|}{ Conference Evaluation } & $600 d$ & Fatr & Poor & \multicolumn{3}{|c|}{ Coments } \\
\hline \multirow{2}{*}{\multicolumn{4}{|c|}{$\begin{array}{l}\text { Fulfillment of Conference Objectives } \\
\text { Appropriateness of Theme } \\
\text { Adequacy of Theme Coverage } \\
\text { Research Adequately Deseribed } \\
\text { Value of R\&D to Industry Clearly } \\
\text { Conveyed } \\
\text { Exciting New Technologies Described } \\
\text { Time Aliotted for Questions } \\
\text { Timing of Conference } \\
\text { Location of Conference } \\
\text { Sequence of Events } \\
\text { Effectiveness of Presentations } \\
\text { Speaker Selection } \\
\text { Audio Visual Materials } \\
\text { Conference Materiais Distribution } \\
\text { Overail Conference Organization } \\
\text { Effectiveness } \\
\text { Registration Procedures }\end{array}$}} & $\begin{array}{l}x \\
x \\
x \\
x \\
x \\
x \\
x\end{array}$ & $x$ & & \multirow{2}{*}{\multicolumn{3}{|c|}{ Lmeren }} \\
\hline & & & & $\begin{array}{l}x \\
x \\
x \\
x \\
x\end{array}$ & & & & & \\
\hline Heeting Room Evaluation & Good & Fair & Poor & \multicolumn{3}{|c|}{ Facility Evaluation } & Good & Fair & Poor \\
\hline $\begin{array}{l}\text { Audio Visual Equipment } \\
\text { light ing } \\
\text { Ventilation } \\
\text { Sound Proofing } \\
\text { Furniture Set Up } \\
\text { Room Cleaniliness } \\
\text { Tea/Coffee }\end{array}$ & $\begin{array}{l}x \\
x \\
x \\
x \\
x\end{array}$ & & $\frac{x}{x}$ & \multicolumn{3}{|c|}{$\begin{array}{l}\text { Telephone Message } \\
\text { Service } \\
\text { Transportation } \\
\text { Food Services } \\
\text { Hotel Room Lodging } \\
\text { Clean Up Services } \\
\text { Facllity Location } \\
\text { Ancillary Services } \\
\text { at Facility }\end{array}$} & $x$ & & \\
\hline
\end{tabular}

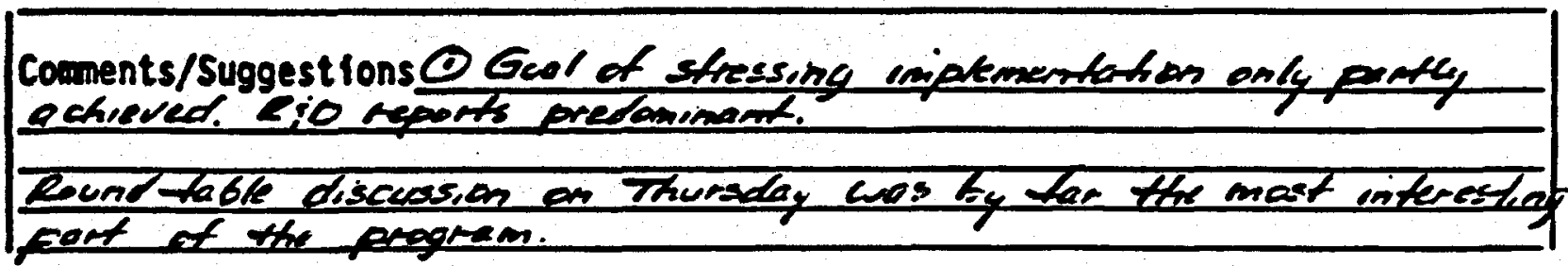
avered, good job! 


\begin{tabular}{|c|c|c|c|c|c|c|c|c|c|}
\hline Conference Evaluation & & & & Tood & Fair & Poor & & ments & \\
\hline $\begin{array}{l}\text { Fulfillment of Conferenc } \\
\text { Appropriateness of Theme } \\
\text { Adequacy of Theme Covera } \\
\text { Research Adequately Desc } \\
\text { Value of R\&D to Industry } \\
\text { Conveyed } \\
\text { Excit ing New Technologie } \\
\text { Time Al Iotted for Questi } \\
\text { Timing of Conference } \\
\text { Socation of Conference } \\
\text { Sequence of Events } \\
\text { Effectiveness of Present } \\
\text { Speaker Selection } \\
\text { Audio Visual Materials } \\
\text { Conference Materiais Dis } \\
\text { Overail Conference Organ } \\
\text { Effectiveness } \\
\text { Registration Procedures } \\
\text { Tegition }\end{array}$ & $\begin{array}{l}\text { Objec } \\
\text { ibed } \\
\text { clearl } \\
\text { Descr } \\
\text { is } \\
\text { ions } \\
\text { tibuti } \\
\text { Lation }\end{array}$ & $\begin{array}{l}\text { ctives } \\
\text { Ty } \\
\text { ribed } \\
\text { ion } \\
n\end{array}$ & & $\begin{array}{l}x \\
x \\
x \\
x \\
x\end{array}$ & $\begin{array}{l}x \\
x \\
x \\
x \\
x \\
x \\
x \\
x\end{array}$ & & & & \\
\hline Meeting Room Evaluation & Good & Fair & Poor & Facil & ity Ev & aluation & $600 d$ & Fair & Poor \\
\hline $\begin{array}{l}\text { Audio Visual Equipment } \\
\text { Lighting } \\
\text { Ventllation } \\
\text { Sound Proofing } \\
\text { Furniture Set Up } \\
\text { Room Cleanliness } \\
\text { Tea/Coffee }\end{array}$ & $\begin{array}{l}x \\
x \\
x \\
x \\
x \\
x\end{array}$ & $x$ & & $\begin{array}{c}\text { Teleph } \\
\text { Serv } \\
\text { Transp } \\
\text { Food S } \\
\text { Hotel } \\
\text { Clean } \\
\text { Facili } \\
\text { Ancili } \\
\text { at F }\end{array}$ & $\begin{array}{l}\text { one Me } \\
\text { ice } \\
\text { ortati } \\
\text { ervice } \\
\text { Room L } \\
\text { Up Ser } \\
\text { ty Loc } \\
\text { ary Se } \\
\text { acilit }\end{array}$ & $\begin{array}{l}\text { ssage } \\
\text { on } \\
\text { s } \\
\text { odging } \\
\text { vices } \\
\text { ation } \\
\text { rvices } \\
y\end{array}$ & $x$ & & \\
\hline
\end{tabular}

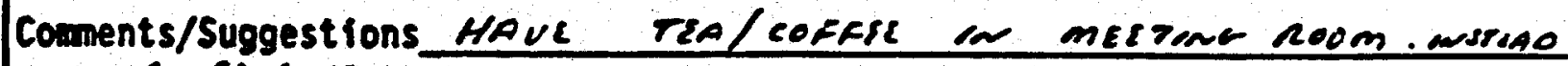
or a siparazi reom. 
Post-Conference Evaluation Form

U.S. Department of Energy

Annual Geothernal Progran Review

Apri1 19-21, 1988

Travelodge at the tharf

San Francisco, CA

FEDERAL GOVT.

\begin{tabular}{|c|c|c|c|c|c|c|c|c|c|}
\hline Conference Evaluation & & & & $600 d$ & Fair & Poor & $\mathrm{Com}$ & Dents & \\
\hline $\begin{array}{l}\text { Fulfillment of Conferen } \\
\text { Appropriateness of Them } \\
\text { Adequacy of Theme Cover } \\
\text { Research Adequately Des } \\
\text { Value of R\&D to Industr } \\
\text { Conveyed } \\
\text { Excit ing New Technologi } \\
\text { Time Al Iotted for Quest } \\
\text { Timing of Conference } \\
\text { Locat ion of Conference } \\
\text { Sequence of Events } \\
\text { Effect iveness of Present } \\
\text { Speaker Selection } \\
\text { Audio Visual Materiais } \\
\text { Conference Materials Dis } \\
\text { Overall Conference Orgar } \\
\text { Effectiveness } \\
\text { Registration Procedures }\end{array}$ & $\begin{array}{l}\text { Objec } \\
\text { ibed } \\
\text { clear } \\
\text { Deser } \\
\text { ns. } \\
\text { tions } \\
\text { ribut } \\
\text { zatios }\end{array}$ & $\begin{array}{l}\text { etives } \\
\text { ribed } \\
\text { ion }\end{array}$ & & $\frac{\sigma}{2} \frac{\sigma}{2}$ & - & & I comes. & - vaey & 6008 \\
\hline Heeting Room Evaluation & Good & Fair & Poor & Facti & ty Ev: & aluation & $600 d$ & Fair & Poor \\
\hline $\begin{array}{l}\text { Audio Visual Equipment } \\
\text { Lighting } \\
\text { Ventilation } \\
\text { Sound Proofing } \\
\text { Furniture Set Up } \\
\text { Room Cleaniliness } \\
\text { Tea/Coffee }\end{array}$ & $\begin{array}{l}\approx \\
\approx \\
\approx\end{array}$ & & & $\begin{array}{c}\text { Teleph } \\
\text { Serv } \\
\text { Transp } \\
\text { Food S } \\
\text { Hotel } \\
\text { Clean } \\
\text { Facili } \\
\text { Ancili } \\
\text { at F }\end{array}$ & $\begin{array}{l}\text { one Mes } \\
\text { ice } \\
\text { ortatio } \\
\text { ervices } \\
\text { Room Lo } \\
\text { Up Ser } \\
\text { ty Loc } \\
\text { ary Ser }\end{array}$ & $\begin{array}{l}\text { ssage } \\
\text { on } \\
\text { s } \\
\text { odging } \\
\text { vices } \\
\text { ation } \\
\text { rvices } \\
\text { y }\end{array}$ & $\begin{array}{c}2 \\
- \\
\text { Nor } \\
\operatorname{mor} \\
- \\
- \\
\text { mor }\end{array}$ & $\mid \begin{array}{c} \\
\text { coses } \\
\text { cses } \\
\\
\text { peses }\end{array}$ & \\
\hline
\end{tabular}

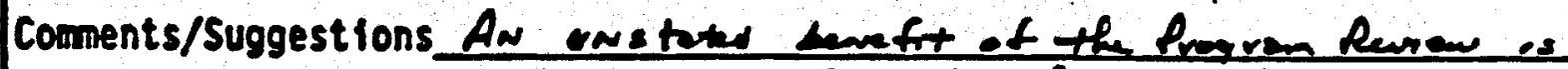

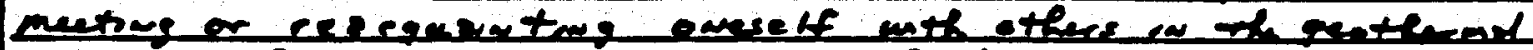

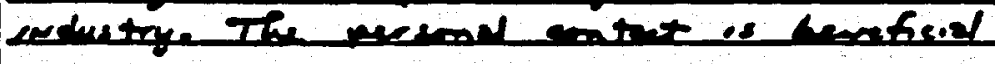


Post-Conference Evaluation Form

U.S. Department of Energy

Annual Geothernal Progran Review

April 19-21, 1988

Travelodge at the tharf

San Francisco, CA

FEDERAL GOVT.

\begin{tabular}{|c|c|c|c|c|c|c|c|c|c|}
\hline \multicolumn{4}{|l|}{ Conference Evaluation } & $600 d$ & Fair & Poor & \multicolumn{3}{|c|}{ Coments } \\
\hline \multicolumn{4}{|c|}{$\begin{array}{l}\text { Fulfillment of Conference Objectives } \\
\text { Appropriateness of Theme } \\
\text { Adequacy of Theme Coverage } \\
\text { Research Adequately Described } \\
\text { Value of R\&D to Industry Clearly } \\
\text { Conveyed } \\
\text { Exciting New Technologies Described } \\
\text { Time Aliotted for Questions } \\
\text { Timing of Conference } \\
\text { Location of Conference } \\
\text { Sequence of Events } \\
\text { Effectiveness of Presentations } \\
\text { Speaker SeTection } \\
\text { Audio Visual Materials } \\
\text { Conference Materials Distribution } \\
\text { Overall Conference Organization } \\
\text { Effectiveness } \\
\text { Registration Procedures }\end{array}$} & & & $\begin{array}{l}\mathbf{x} \\
\mathbf{x} \\
\mathbf{x}\end{array}$ & & & \\
\hline Meeting Room Evaluation & 600d & Fair & Poor & \multicolumn{3}{|c|}{ Facility Evaluation } & 600d & Fair & Poor \\
\hline $\begin{array}{l}\text { Audio Visual Equipment } \\
\text { Lighting } \\
\text { Ventilation } \\
\text { Sound Proofing } \\
\text { Furniture Set Up } \\
\text { Room Cleanifiness } \\
\text { Tea/Coffee }\end{array}$ & & & $\begin{array}{l}x \\
x\end{array}$ & \multicolumn{3}{|c|}{$\begin{array}{l}\text { Telephone Message } \\
\text { Service } \\
\text { Transportation } \\
\text { Food Services } \\
\text { Hotel Room Lodging } \\
\text { Clean Up Services } \\
\text { Facility Location } \\
\text { Ancilliary Services } \\
\text { at Facility }\end{array}$} & & & \\
\hline
\end{tabular}

Coments/Suggestions I walked out after the first day. The meeting was a complete raste of EIme. 
Post-Conference Evaluation Form

U.S. Department of Energy

Annual Geotheral Progras Review

April 19-21, 1988

Travelodge at the tharf

San Francisco, CA

FEDERAL GOVT.

\begin{tabular}{|c|c|c|c|c|c|c|c|c|c|}
\hline \multicolumn{4}{|l|}{ Conference Evaluation } & 6ood & Fair & Poor & $\cos$ & ments & \\
\hline \multicolumn{4}{|c|}{$\begin{array}{l}\text { Fulfillment of Conference Objectives } \\
\text { Appropriateness of Theme } \\
\text { Adequacy of Theme Coverage } \\
\text { Research Adequately Described } \\
\text { Value of RLD to Industry Clearly } \\
\text { Conveyed } \\
\text { Exciting New Technologies Described } \\
\text { Time Aliotted for Questions } \\
\text { Timing of Conference } \\
\text { Location of Conference } \\
\text { Sequence of Events } \\
\text { Effectiveness of Presentations } \\
\text { Speaker Selection } \\
\text { Audio Visual Materials } \\
\text { Conference Materiais Distribution } \\
\text { Overali Conference Organization } \\
\text { Effectiveness } \\
\text { Registration Procedures }\end{array}$} & & & & & & \\
\hline Heeting Room Evaluation & Good & Fair & Poor & \multicolumn{3}{|c|}{ Facility Evaluation } & Good & Fair & $\overline{\text { Poor }}$ \\
\hline $\begin{array}{l}\text { Audio Visual Equipment } \\
\text { Lighting } \\
\text { Ventilation } \\
\text { Sound Proofing } \\
\text { Furniture Set Up } \\
\text { Room Cleani iness } \\
\text { Tea/Coffee }\end{array}$ & & & & \multicolumn{3}{|c|}{$\begin{array}{l}\text { Telephone Message } \\
\text { Service } \\
\text { Transportation } \\
\text { Food Services } \\
\text { Hotel Room Lodging } \\
\text { Clean Up Services } \\
\text { Facility Location } \\
\text { Anciliary Services } \\
\text { at Facility }\end{array}$} & & & \\
\hline
\end{tabular}

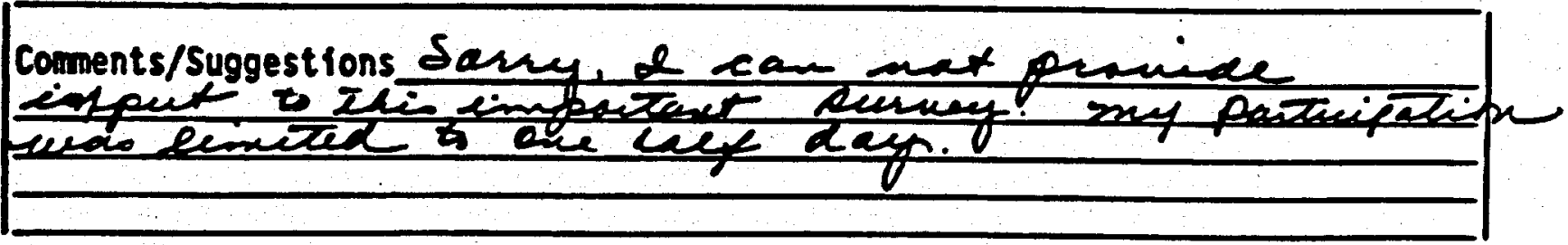


Post-Conference Evaluation Form

U.S. Department of Energy.

Annual Geothermal Program Review

Apri1 19-21, 1988

Travelodge at the tharf

San Francisco, CA

INDUSTRY

\begin{tabular}{|c|c|c|c|c|c|c|c|c|c|}
\hline Conference Evaluation & & & & Good & Fair & Poor & Com & ments & \\
\hline $\begin{array}{l}\text { Fulfillment of Conferenc } \\
\text { Appropriateness of Theme } \\
\text { Adequacy of Theme Covera } \\
\text { Research Adequately Desc } \\
\text { Value of R\&D to Industry } \\
\text { Conveyed } \\
\text { Exciting New Technologie } \\
\text { Time Aliotted for Questi } \\
\text { Timing of Conference } \\
\text { Location of Conference } \\
\text { Sequence of Events } \\
\text { Effectiveness of Present } \\
\text { Speaker Selection } \\
\text { Audio Visual Materials } \\
\text { Conference Materials Dis } \\
\text { Overali Conference Organ } \\
\text { Effectiveness } \\
\text { Registration Procedures }\end{array}$ & $\begin{array}{l}\text { Objec } \\
\text { ibed } \\
\text { clearl } \\
\text { Descr } \\
\text { ns } \\
\text { tions } \\
\text { ribut } \\
\text { zation }\end{array}$ & tives & & $\begin{array}{l}x \\
x \\
k \\
\alpha \\
k \\
\alpha\end{array}$ & $\begin{array}{l}\alpha \\
\alpha \\
\alpha \\
\alpha\end{array}$ & $\frac{\alpha}{x}$ & & & \\
\hline Meeting Room Evaluation & Good & Fair & Poor & Facil & Ifty Eve & $\frac{1}{\text { aluation }}$ & Good & Fair & Poor \\
\hline $\begin{array}{l}\text { Audio Visual Equipment } \\
\text { Lighting } \\
\text { Ventilation } \\
\text { Sound Proofing } \\
\text { Furniture Set Up } \\
\text { Room Cleanl iness } \\
\text { Tea/Coffee }\end{array}$ & & $\begin{array}{l}\alpha \\
\alpha \\
\alpha \\
\alpha \\
x \\
\alpha\end{array}$ & & $\begin{array}{l}\text { Teleph } \\
\text { Serv } \\
\text { Transp } \\
\text { Food S } \\
\text { Hotel } \\
\text { Clean } \\
\text { Facili } \\
\text { Ancill } \\
\text { at F F }\end{array}$ & $\begin{array}{l}\text { lone Mes } \\
\text { lice } \\
\text { portatic } \\
\text { Service } \\
\text { Room Le } \\
\text { Up Ser } \\
\text { ity Loc } \\
\text { lary Se } \\
\text { facilift }\end{array}$ & $\begin{array}{l}\text { ssage } \\
\text { on } \\
\text { s } \\
\text { odging } \\
\text { vices } \\
\text { ation } \\
\text { arvices } \\
y\end{array}$ & & $\begin{array}{l}\alpha \\
x \\
\alpha\end{array}$ & \\
\hline
\end{tabular}

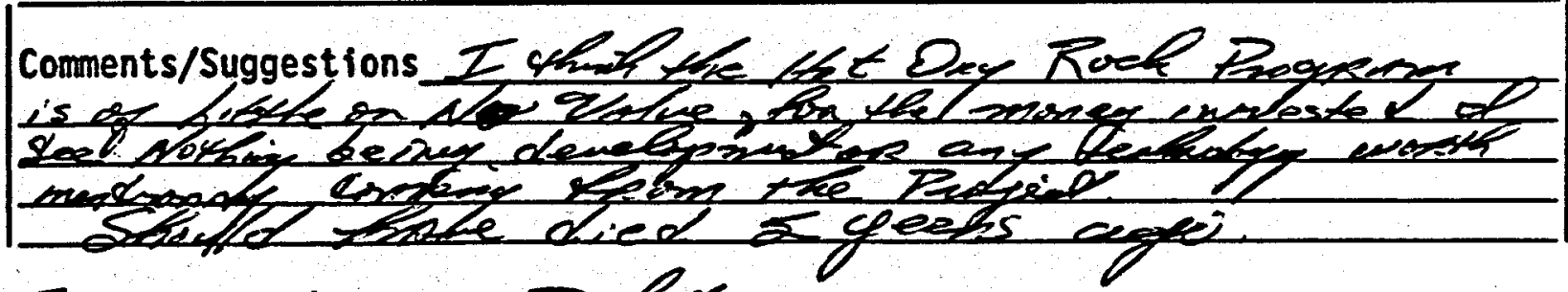

Tosves: $R \& D$ to Twals

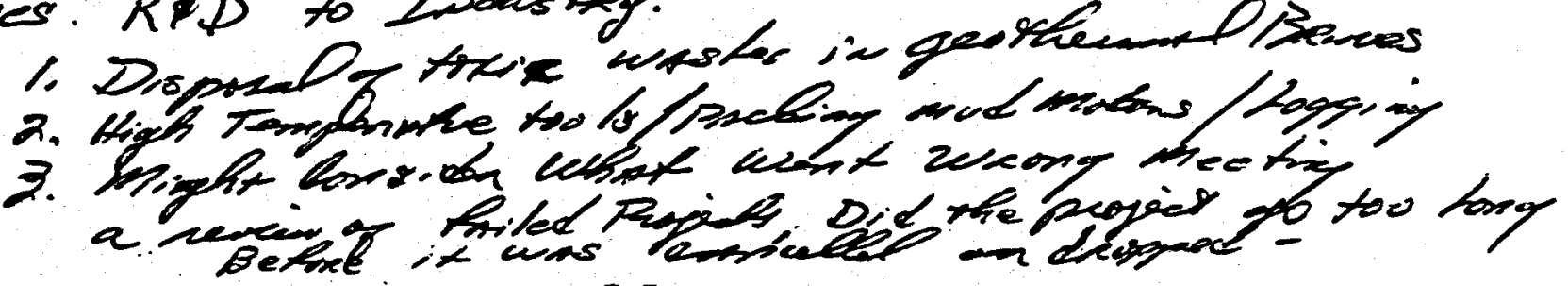


ontive?

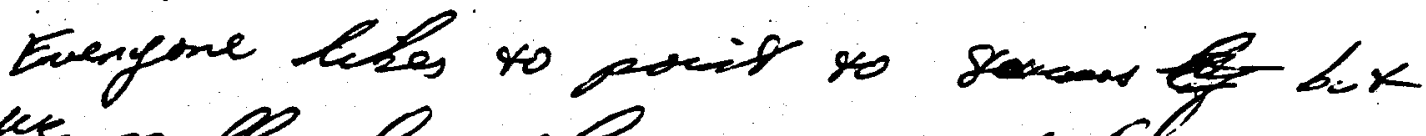

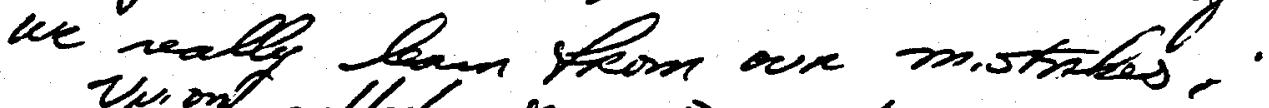

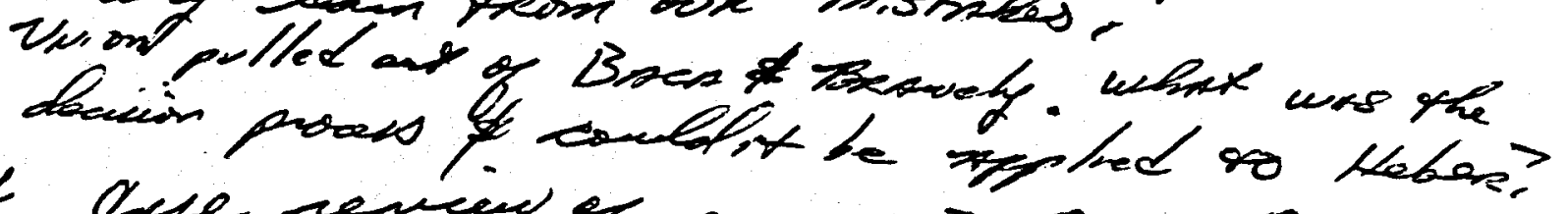

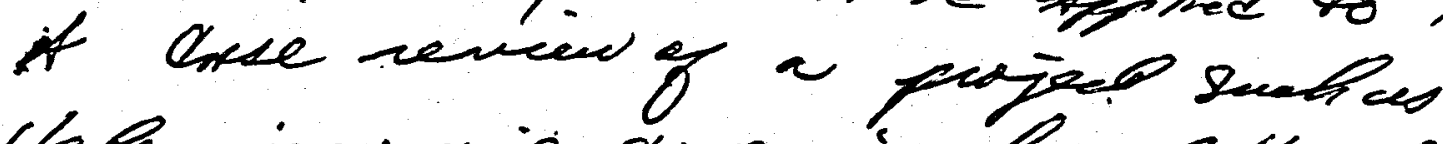

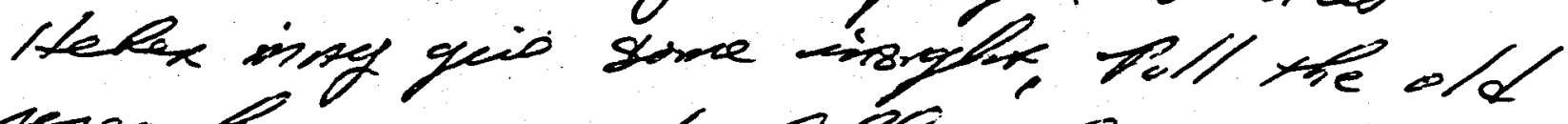
reseant papen wnd follow thes rests theogel sto the pcesse? Not to Shaw whet rsectle wes wrong on wiph the why

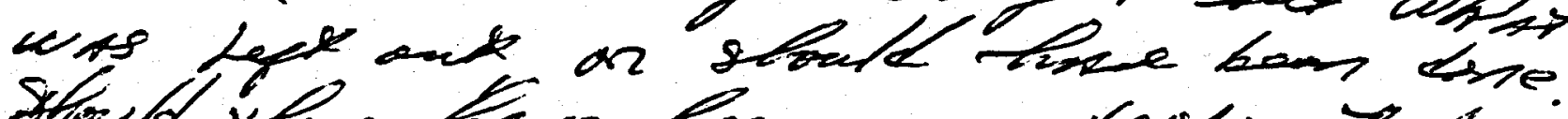
Shold the tere teen more keshing of the

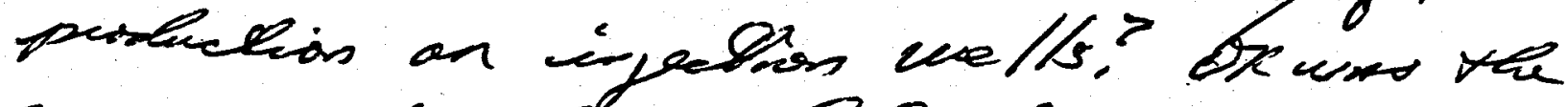

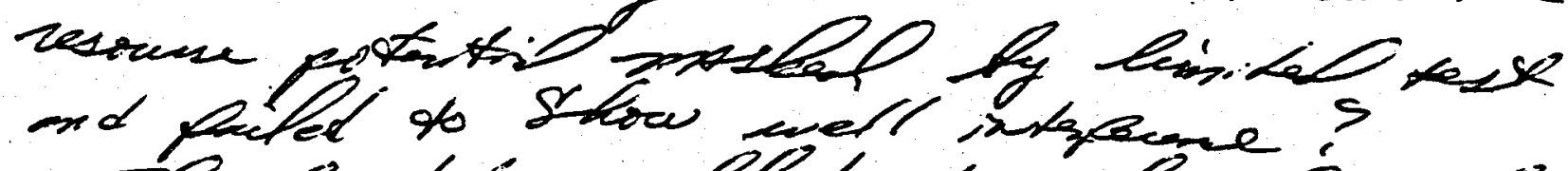

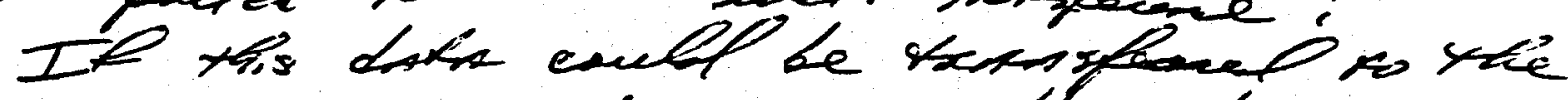

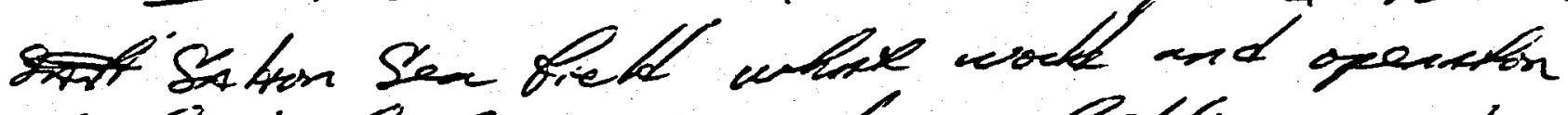

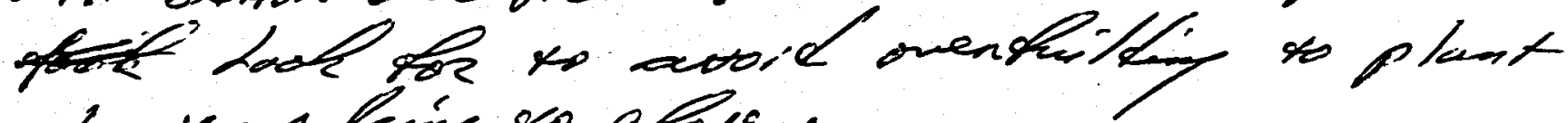
hocowors heig so elape.

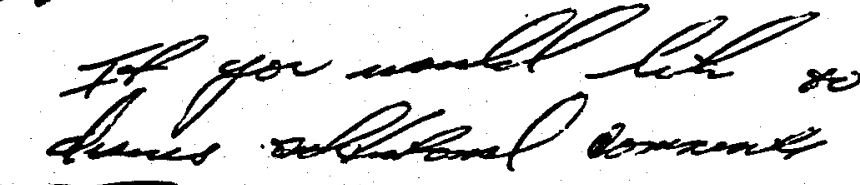
ite crell. 
Post-Conference Evaluation Form

U.S. Department of Energy

Annual Geothermal Program Review

Apri1 19-21, 1988

Travelodge at the tharf

San Francisco, CA

INDUSTRY

\begin{tabular}{|c|c|c|c|c|c|c|c|c|c|}
\hline Conference Evaluation & & & & Good & Fair & Poor & Com & ments & \\
\hline $\begin{array}{l}\text { Fulfillment of Conferenc } \\
\text { Appropriateness of Theme } \\
\text { Adequacy of Theme Covera } \\
\text { Research Adequately Desc } \\
\text { Value of R\&D to Industry } \\
\text { Conveyed } \\
\text { Exciting New Technologie } \\
\text { Time Allotted for Questi } \\
\text { Timing of Conference } \\
\text { Location of Conference } \\
\text { Sequence of Events } \\
\text { Effectiveness of Present } \\
\text { Speaker Selection } \\
\text { Audio Visual Materials } \\
\text { Conference Materials Dis } \\
\text { Overall Conference Organ } \\
\text { Effectiveness } \\
\text { Registration Procedures }\end{array}$ & $\begin{array}{l}\text { Objec } \\
\text { e } \\
\text { ibed } \\
\text { Clearl } \\
\text { Descr } \\
\text { ns } \\
\\
\text { tions } \\
\text { ributi } \\
\text { zation }\end{array}$ & tives & & $\frac{1}{2}$ & $\frac{1}{6}$ & & & & \\
\hline Meeting Room Evaluation & Good & Fair & Poor & Facil & ity Ev & $\frac{1}{\text { aluation }}$ & Good & Fair & Poor \\
\hline $\begin{array}{l}\text { Audio Visual Equipment } \\
\text { Lighting } \\
\text { Ventilation } \\
\text { Sound Proofing } \\
\text { Furniture Set Up } \\
\text { Room Cleanliness } \\
\text { Tea/Coffee }\end{array}$ & 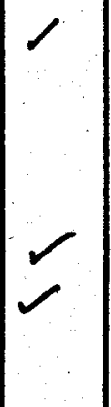 & & & $\begin{array}{r}\text { Teleph } \\
\text { Serv } \\
\text { Transp } \\
\text { Food S } \\
\text { Hotel } \\
\text { Clean } \\
\text { Facily } \\
\text { Ancill } \\
\text { at F }\end{array}$ & $\begin{array}{l}\text { one Me } \\
\text { ice } \\
\text { ortatt } \\
\text { ervice } \\
\text { Room L } \\
\text { Up Ser } \\
\text { ty Loc } \\
\text { ary Se } \\
\text { acilit }\end{array}$ & $\begin{array}{l}\text { ssage } \\
\text { on } \\
\text { s } \\
\text { odging } \\
\text { vices } \\
\text { ation } \\
\text { rvices } \\
y\end{array}$ & & - & \\
\hline
\end{tabular}

Comments/Suggestions 
Post-Conference Evaluation Form

U.S. Department of Energy

Annual Geothermal Program Review

Apri) 19-21, 1988

Travelodge at the Hharf

San Francisco, CA

INDUSTRY

\begin{tabular}{|c|c|c|c|c|c|c|c|c|c|}
\hline Conference Evaluation & & & & Good & Fair & Poor & Com & ments & \\
\hline $\begin{array}{l}\text { Fulfillment of Conference } \\
\text { Appropriateness of Theme } \\
\text { Adequacy of Theme Coverac } \\
\text { Research Adequately Desci } \\
\text { Value of R\&D to Industry } \\
\text { Conveyed } \\
\text { Exciting New Technologie } \\
\text { Time Allotted for Questi } \\
\text { Timing of Conference } \\
\text { Location of Conference } \\
\text { Sequence of Events } \\
\text { Effectiveness of Present } \\
\text { Speaker Selection } \\
\text { Audio Visual Materials } \\
\text { Conference Materials Dis } \\
\text { Overall Conference Organ } \\
\text { Effectiveness } \\
\text { Registration Procedures }\end{array}$ & $\begin{array}{l}\text { Object } \\
\text { bed } \\
\text { learly } \\
\text { Descr } \\
s \\
\text { ions } \\
\text { ibuti } \\
\text { ation }\end{array}$ & $\begin{array}{l}\text { tives } \\
\text { ibed } \\
\text { on }\end{array}$ & & & & & & & \\
\hline Meeting Room Evaluation & Good & Fair & Poor & Facil & ity Ev & aluation & Good & Fair & Poor \\
\hline $\begin{array}{l}\text { Audio Visual Equipment } \\
\text { Lighting } \\
\text { Ventilation } \\
\text { Sound Proofing } \\
\text { Furniture Set Up } \\
\text { Room Cleanl iness } \\
\text { Tea/Coffee }\end{array}$ & - & 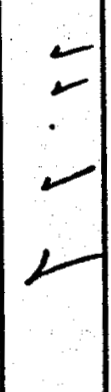 & & $\begin{array}{c}\text { Teleph } \\
\text { Serv } \\
\text { Transp } \\
\text { Food S } \\
\text { Hotel } \\
\text { Clean } \\
\text { Facil } \\
\text { Ancill } \\
\text { at }\end{array}$ & $\begin{array}{l}\text { one Me } \\
\text { ice } \\
\text { ortati } \\
\text { ervice } \\
\text { Room L } \\
\text { Up Ser } \\
\text { ty Loc } \\
\text { ary Se } \\
\text { acilit }\end{array}$ & $\begin{array}{l}\text { ssage } \\
\text { on } \\
\text { s } \\
\text { odging } \\
\text { vices } \\
\text { :ation } \\
\text { ervices } \\
\text { y }\end{array}$ & 4 & & \\
\hline
\end{tabular}

\section{Comments/Suggestions}


Post-Conference Evaluation Form

U.S. Department of Energy

Annual Geothermal Program Review

Apri1 19-21, 1988

Travelodge at the tharf

San Francisco, CA

INDUSTRY

\begin{tabular}{|c|c|c|c|c|c|c|c|c|c|}
\hline Conference Evaluation & & & & Tood & Fair & Poor & Com & ments & \\
\hline $\begin{array}{l}\text { Fulfillment of Conferenc } \\
\text { Appropriateness of Theme } \\
\text { Adequacy of Theme Covera } \\
\text { Research Adequately Desc } \\
\text { Value of R\&D to Industry } \\
\text { Conveyed } \\
\text { Exciting New Technologie } \\
\text { Time Aliotted for Questi } \\
\text { Timing of Conference } \\
\text { Location of Conference } \\
\text { Sequence of Events } \\
\text { Effectiveness of Present } \\
\text { Speaker Selection } \\
\text { Audio Visual Materials } \\
\text { Conference Materials Dis } \\
\text { Overall Conference Organ } \\
\text { Effectiveness } \\
\text { Registration Procedures }\end{array}$ & $\begin{array}{l}\text { Objec } \\
\text { e } \\
\text { ibed } \\
\text { clearl } \\
\text { Descr } \\
\text { ns } \\
\text { tions } \\
\text { ributi } \\
\text { zation }\end{array}$ & in & & $\frac{2}{2}$ & $\begin{array}{l}2 \\
2 \\
v\end{array}$ & & & & \\
\hline Meeting Room Evaluation & Good & Fair & Poor & Facil & ity Ev & aluation & Good & Fair & Poor \\
\hline $\begin{array}{l}\text { Audio Visual Equipment } \\
\text { Lighting } \\
\text { Ventilation } \\
\text { Sound Proofing } \\
\text { Furniture Set Up } \\
\text { Room Cleanliness } \\
\text { Tea/Coffee }\end{array}$ & & & & $\begin{array}{c}\text { Teleph } \\
\text { Ser } \\
\text { Transp } \\
\text { food } \\
\text { Hotel } \\
\text { Clean } \\
\text { Facil } \\
\text { Ancil } \\
\text { at }\end{array}$ & $\begin{array}{l}\text { one Me } \\
\text { ice } \\
\text { ortati } \\
\text { ervice } \\
\text { Room L } \\
\text { Up Ser } \\
\text { ty Loc } \\
\text { ary Se } \\
\text { acilit }\end{array}$ & $\begin{array}{l}\text { ssage } \\
\text { on } \\
\text { s } \\
\text { odging } \\
\text { vices } \\
\text { ation } \\
\text { rvices } \\
y\end{array}$ & & & \\
\hline
\end{tabular}

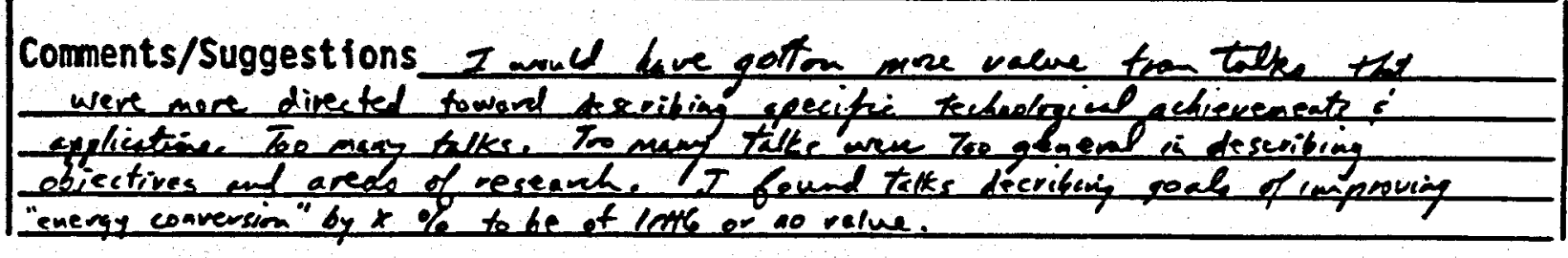


Post-Conference Evaluation Fort

U.S. Department of Energy

Annual Geothernal Progran Review

April 19-21, 1988

Travelodge at the tharf

San Francisco, CA

INDUSTRY

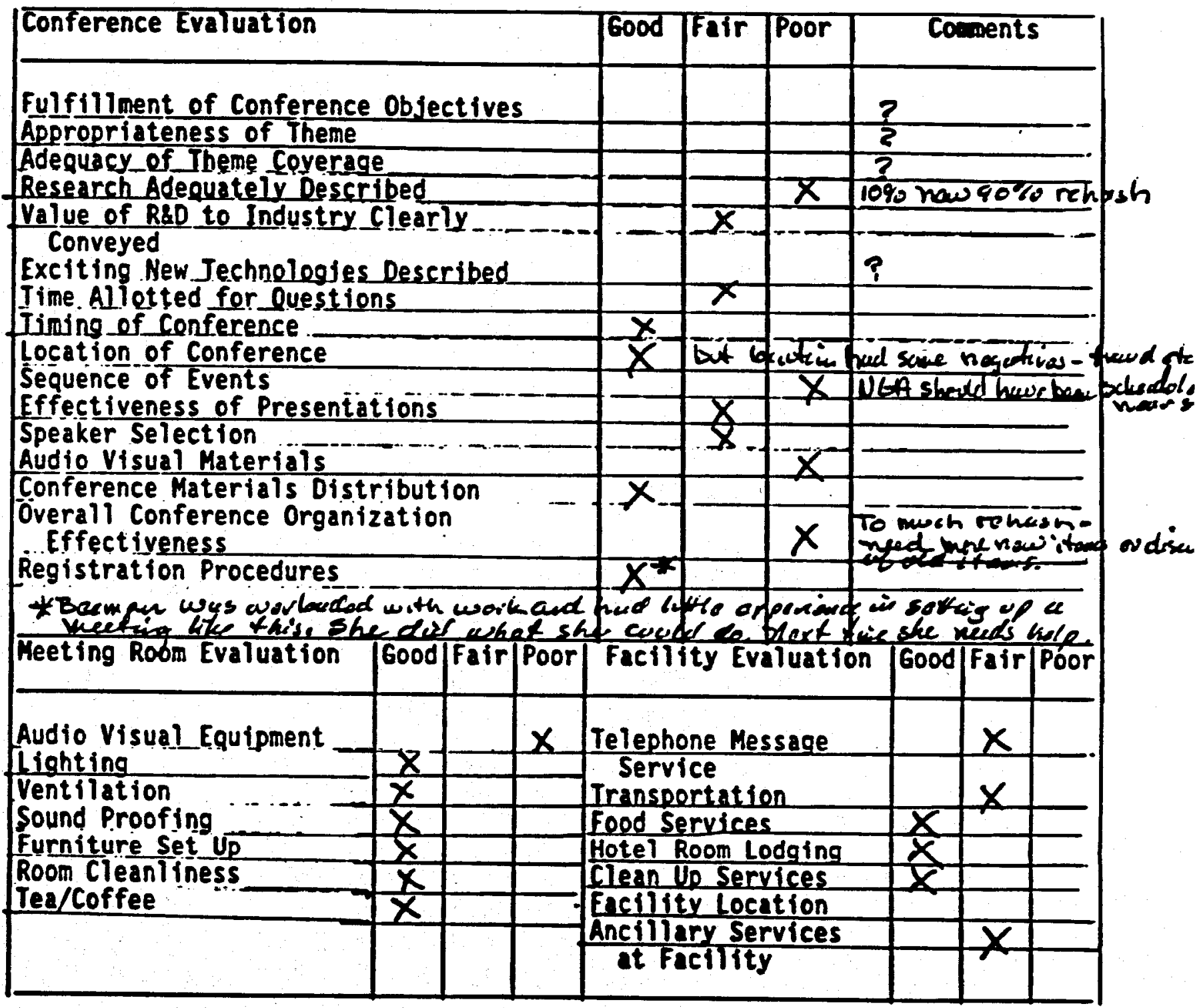
Corments/Suggest ions Sereen to small, PA systan did not workwoll,

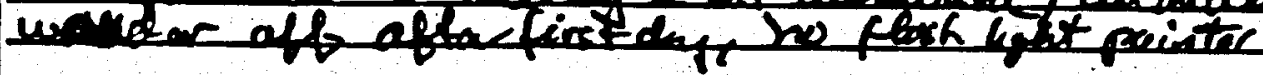

Carole: If yw are inowlend in aceother one of there plase call ¿crace and get same pointous. with gost wit a latte wifo. things wold hawe been mewh bottor. Atang in there you' derieg a geod job but ave hot goting ung sepport? 
Post-Conference Evaluation Form

U.S. Department of Energy

Annual Geothermal Progran Review

April 19-21, 1988

Travelodge at the tharf

San Francisco, CA

INDUSTRY

\begin{tabular}{|c|c|c|c|c|c|c|c|c|c|}
\hline Conference Evaluation & & & & Good & Fair & Poor & $\operatorname{com}$ & iments & \\
\hline $\begin{array}{l}\text { Fulfillment of Conference } \\
\text { Appropriateness of Theme } \\
\text { Adequacy of Theme Coveras } \\
\text { Research Adequately Desc } \\
\text { Value of R\&D to Industry } \\
\text { Conveyed } \\
\text { Exciting New Technologies } \\
\text { Time AlIotted for Questic } \\
\text { Timing of Conference } \\
\text { Location of Conference } \\
\text { Sequence of Events } \\
\text { Effectiveness of Present } \\
\text { Speaker Selection } \\
\text { Audio Visual Materials } \\
\text { Conference Materials Dis } \\
\text { Overall Conference Organ } \\
\text { Effectiveness } \\
\text { Registration Procedures }\end{array}$ & $\begin{array}{l}\text { Objec } \\
\text { ibed } \\
\text { clearl } \\
\text { Deser } \\
\text { ns } \\
\text { tions } \\
\text { ributi } \\
\text { zation }\end{array}$ & $\begin{array}{l}\text { Itives } \\
\text { ibed } \\
\text { ion }\end{array}$ & & $\begin{array}{l}x \\
x \\
x \\
x \\
x \\
x \\
x \\
x \\
x\end{array}$ & $\begin{array}{l}x \\
x\end{array}$ & & & & \\
\hline Heeting Room Evaluation & Good & Fair & Poor & Facil & ity Ev & aluation & $600 d$ & Fair & Poor \\
\hline $\begin{array}{l}\text { Audio Visual Equipment } \\
\text { Light ing } \\
\text { Ventilation } \\
\text { Sound Proofing } \\
\text { Furniture Set Up } \\
\text { Room Cleanliness } \\
\text { Tea/Coffee }\end{array}$ & $\begin{array}{l}x \\
x \\
x\end{array}$ & $\begin{array}{l}x \\
x \\
y\end{array}$ & & $\mid \begin{array}{c}\text { Telepl } \\
\text { Ser } \\
\text { Trans! } \\
\text { Food } \\
\text { Hotel } \\
\text { Clean } \\
\text { Facil } \\
\text { Ancli } \\
\text { at }\end{array}$ & $\begin{array}{l}\text { one Me } \\
\text { ice } \\
\text { ortati } \\
\text { ervice } \\
\text { Room L } \\
\text { Up Ser } \\
\text { ty Loc } \\
\text { ary Se } \\
\text { actilt }\end{array}$ & $\begin{array}{l}\text { ssage } \\
\text { on } \\
\text { s } \\
\text { odging } \\
\text { vices } \\
\text { ation } \\
\text { avices } \\
\text { y }\end{array}$ & $\begin{array}{l}x \\
x \\
x \\
x \\
x\end{array}$ & $\underset{x}{x}$ & \\
\hline
\end{tabular}

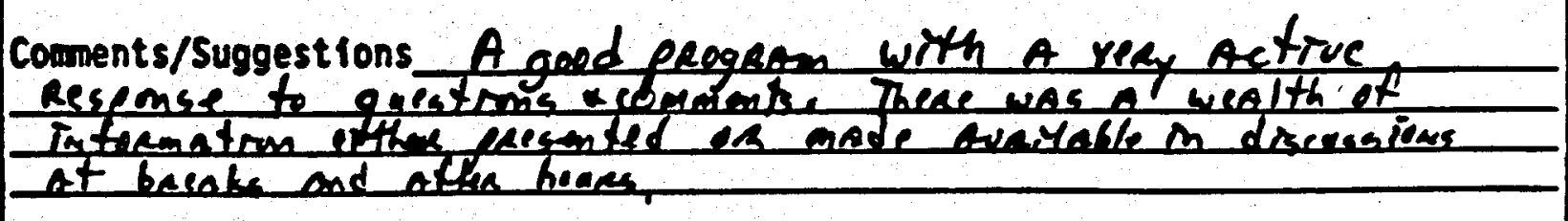


Post-Conference Evaluation Form

U.S. Departwent of Energy

Annual Geothermal Progran Review

April 19-21, 1988

Travelodge at the tharf

San Francisco, CA

INDUSTRY

\begin{tabular}{|c|c|c|c|c|c|c|c|c|c|}
\hline Conference Evaluation & & & & Good & Fair & Poor & $\operatorname{com}$ & ments & \\
\hline $\begin{array}{l}\text { Fulfillment of Conferenc } \\
\text { Appropriateness of Theme } \\
\text { Adequacy of Theme Covera } \\
\text { Research Adequately Dese } \\
\text { Value of R\&D to Industry } \\
\text { Conveyed } \\
\text { Exciting New Technologie } \\
\text { Time Aliotted for Questi } \\
\text { Timing of Conference } \\
\text { Location of Conference } \\
\text { Sequence of Events } \\
\text { Effectiveness of Present } \\
\text { Speaker Selection } \\
\text { Audio Visual Materials } \\
\text { Conference Materials Dis } \\
\text { Overali Conference Organ } \\
\text { Effectiveness } \\
\text { Registration Procedures }\end{array}$ & $\begin{array}{l}\text { Objec } \\
\text { bed } \\
\text { iear } \\
\text { Descr } \\
\text { s } \\
\text { ions } \\
\text { ibut } \\
\text { ation }\end{array}$ & $\begin{array}{l}\text { tives } \\
\text { ibed } \\
\text { ion }\end{array}$ & & & $\checkmark$ & & the & tas & $\begin{array}{l}\text { sions } \\
\text { inch! } \\
\text { tond }\end{array}$ \\
\hline Heeting Room Evaluation & Good & Fair & Poor & Facil & ity Ev & aluation & 6ood & Fair & Poor \\
\hline $\begin{array}{l}\text { Audio Visual Equipment } \\
\text { Lighting } \\
\text { Vent ilation } \\
\text { Sound Proofing } \\
\text { Furniture Set Up } \\
\text { Room Cleanliness } \\
\text { Tea/Coffee }\end{array}$ & & & & $\begin{array}{c}\text { Teleph } \\
\text { Sery } \\
\text { Transp } \\
\text { Food S } \\
\text { Hotel } \\
\text { Clean } \\
\text { Facil } \\
\text { Ancili } \\
\text { at F }\end{array}$ & $\begin{array}{l}\text { one Me } \\
\text { ice } \\
\text { ortati } \\
\text { ervice } \\
\text { Room L } \\
\text { Up Ser } \\
\text { ty Loc } \\
\text { ary Se } \\
\text { cilit }\end{array}$ & $\begin{array}{l}\text { ssage } \\
\text { on } \\
\text { s } \\
\text { odging } \\
\text { vices } \\
\text { ation } \\
\text { rvices } \\
y\end{array}$ & & & \\
\hline
\end{tabular}

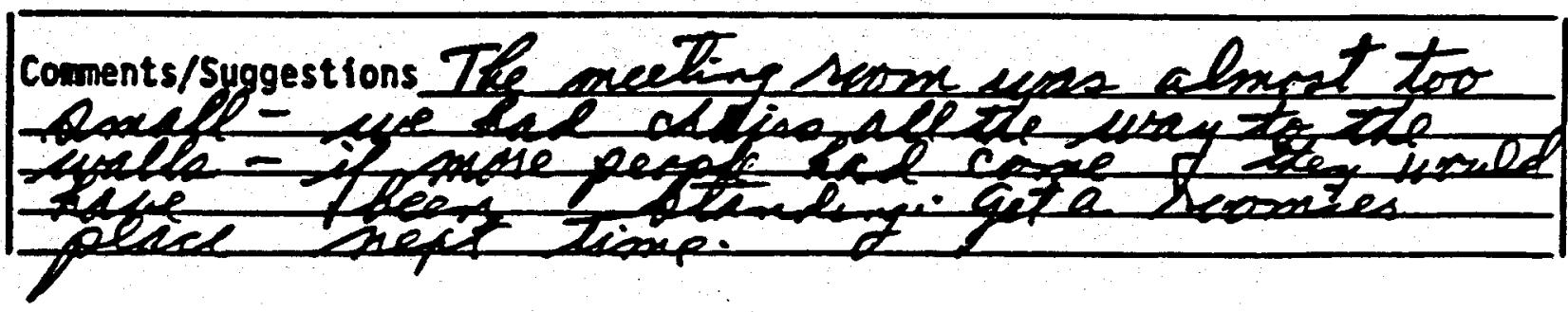


Post-Conference Evaluation Form

U.S. Department of Energy

Annual Geotheral Progran Review

Aprif 19-21, 1988

Travelodge at the tharf

San Francisco, CA

INDUSTRY

\begin{tabular}{|c|c|c|c|c|c|c|c|c|c|}
\hline Conference Evaluation & & & & $600 d$ & Fair & Poor & $\operatorname{Com}$ & ments & \\
\hline $\begin{array}{l}\text { Fulfillment of Conferenc } \\
\text { Appropriateness of Theme } \\
\text { Adequacy of Theme Covera } \\
\text { Research Adequately Desc } \\
\text { Value of R\&D to Industry } \\
\text { Conveyed } \\
\text { Excit ing New Technologie } \\
\text { Time Al otted for Questi } \\
\text { Timing of Conference } \\
\text { Location of Conference } \\
\text { Sequence of Events } \\
\text { Effectiveness of Present } \\
\text { Speaker Selection } \\
\text { Audio Visual Materials } \\
\text { Conference Materials Dis } \\
\text { Overali Conference Organ } \\
\text { Effectiveness } \\
\text { Registration Procedures }\end{array}$ & $\begin{array}{l}\text { Objec } \\
\text { ibed } \\
\text { iear } \\
\text { Deser } \\
\text { is } \\
\text { ions } \\
\text { ibuti } \\
\text { ation }\end{array}$ & $\begin{array}{l}\text { etive: } \\
\text { ilyed } \\
\text { lon }\end{array}$ & & $\begin{array}{l}v \\
v \\
v \\
v \\
v\end{array}$ & $\begin{array}{l}\checkmark \\
\sim \\
v \\
v \\
v \\
v \\
v\end{array}$ & - & & & \\
\hline Heeting Room Evaluation & Good & Fair & Poor & Facil & ty Evi & $\frac{1}{\text { luation }}$ & 6000 & Fair & Poor \\
\hline $\begin{array}{l}\text { Audio Visual Equipment } \\
\text { Lighting } \\
\text { Ventilation } \\
\text { Sound Proofing } \\
\text { Furniture Set Up } \\
\text { Room Cleaniliness } \\
\text { Tea/Coffee }\end{array}$ & $\begin{array}{l}\mathcal{J} \\
\mathcal{J} \\
\mathcal{J}\end{array}$ & $\checkmark$ & & $\begin{array}{l}\text { Teleph } \\
\text { Serv } \\
\text { Transp } \\
\text { Food S } \\
\text { Hotel } \\
\text { Clean } \\
\text { Facili } \\
\text { Anclil } \\
\text { at F }\end{array}$ & $\begin{array}{l}\text { one Mes } \\
\text { ice } \\
\text { ortatic } \\
\text { ervices } \\
\text { Room Le } \\
\text { Up Ser } \\
\text { ty Loce } \\
\text { ary Ser } \\
\text { acilits }\end{array}$ & $\begin{array}{l}\text { sage } \\
\text { on } \\
\text { odging } \\
\text { ices } \\
\text { itfon } \\
\text { vices } \\
\text { vices }\end{array}$ & & le & 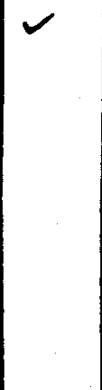 \\
\hline
\end{tabular}

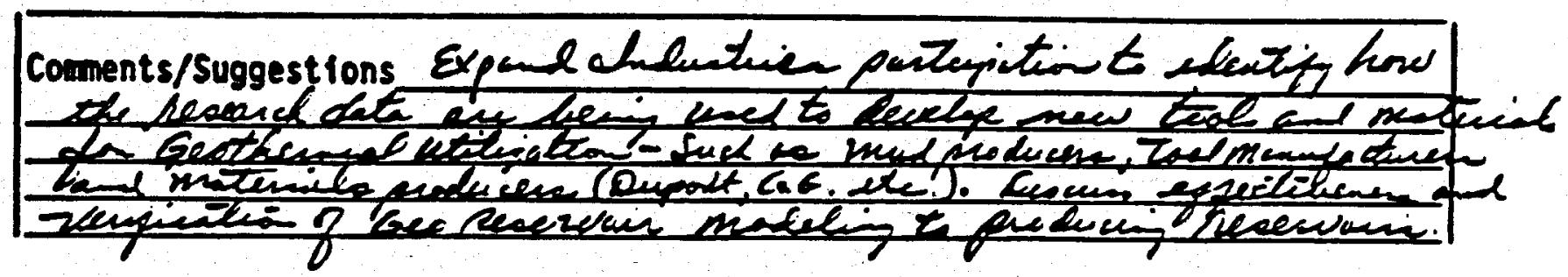


Post-Conference Evaluation Form

U.S. Departwent of Energy

Annual Geothermal Progran Review

April 19-21, 1988

Travelodge at the tharf

San Francisco, CA

INDUSTRY

\begin{tabular}{|c|c|c|c|c|c|c|c|c|c|}
\hline Conference Evaluation & & & & $600 d$ & Fair & Poor & $\cos$ & ments & \\
\hline $\begin{array}{l}\text { Fulfillment of Conferenc } \\
\text { Appropriateness of Theme } \\
\text { Adequacy of Theme Covera } \\
\text { Research Adequately Desc } \\
\text { Value of R\&D to Industry } \\
\text { Conveyed } \\
\text { Exciting New Technologie } \\
\text { Time AlTotted for Questi } \\
\text { Timing of Conference } \\
\text { Socat ion of Conference } \\
\text { Sequence of Events } \\
\text { Effectiveness of Present } \\
\text { Speaker Selection } \\
\text { Audio Visual Materials } \\
\text { Conference Materials Dis } \\
\text { Overall Conference Organ } \\
\text { Effectiveness } \\
\text { Registration Procedures }\end{array}$ & $\begin{array}{l}\text { Objec } \\
\text { bed } \\
\text { learl } \\
\text { Descr } \\
\text { s } \\
\text { ions } \\
\text { ibut } \\
\text { ation }\end{array}$ & tives & & . & & 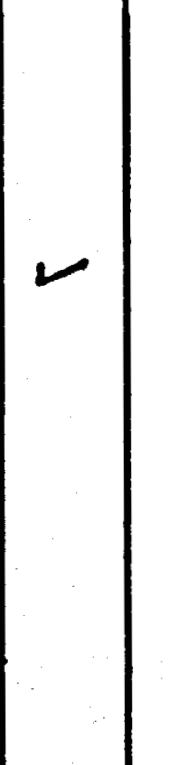 & & & \\
\hline Meeting Room Evaluation & Good & Fair & Poor & Facil & ty Ev & Tuation & Good & Fair| & Poor \\
\hline $\begin{array}{l}\text { Audio Visual Equipment } \\
\text { Lighting } \\
\text { Ventllation } \\
\text { Sound Proofing } \\
\text { Furniture Set Up } \\
\text { Room Cleaniliness } \\
\text { Tea/Coffee }\end{array}$ & & & & $\begin{array}{c}\text { Teleph } \\
\text { Serv } \\
\text { Transp } \\
\text { Food S } \\
\text { Hotel } \\
\text { Clean } \\
\text { Facill } \\
\text { Ancill } \\
\text { ot F }\end{array}$ & $\begin{array}{l}\text { one Me } \\
\text { ice } \\
\text { ortati } \\
\text { ervice } \\
\text { Room L } \\
\text { Jp Ser } \\
\text { ty Loc } \\
\text { iry Se }\end{array}$ & $\begin{array}{l}\text { ssage } \\
\text { on } \\
\text { s } \\
\text { odging } \\
\text { vices } \\
\text { tion } \\
\text { rvices } \\
y\end{array}$ & & $\begin{array}{l}2 \\
6 \\
4\end{array}$ & \\
\hline
\end{tabular}

Comments/Suggestions 
Post-Conference Evaluation Form

U.S. Department of Energy

Annual Geothermal Progran Review

April 19-21, 1988

Travelodge at the tharf

San Francisco, CA

INDUSTRY

\begin{tabular}{|c|c|c|c|c|c|c|c|c|c|}
\hline \multicolumn{4}{|l|}{ Conference Evaluation } & $600 d$ & Tfair & Poor & \multicolumn{3}{|c|}{ Compents } \\
\hline \multicolumn{4}{|c|}{$\begin{array}{l}\text { Fulfillment of Conference Objectives } \\
\text { Appropriateness of Theme } \\
\text { Adequacy of Theme Coverage } \\
\text { Research Adequately Described } \\
\text { Value of R\&D to Industry Clearly } \\
\text { Conveyed } \\
\text { Exciting New Technologies Described } \\
\text { Time Aliotted for Questions } \\
\text { Timing of Conference. } \\
\text { Location of Conference } \\
\text { Sequence of Events } \\
\text { Effectiveness of Presentations } \\
\text { Speaker Select ion } \\
\text { Audio Visual Materials } \\
\text { Conference Materials Distribution } \\
\text { Overali Conference Organization } \\
\text { Effectiveness } \\
\text { Registration Procedures }\end{array}$} & & $\begin{array}{l}x \\
x \\
x \\
x \\
x \\
x \\
x \\
x\end{array}$ & $\begin{array}{l}x \\
x \\
x\end{array}$ & \multicolumn{3}{|l|}{ unkn. } \\
\hline Meeting Room Evaluation & Good & Fair & Poor & \multicolumn{3}{|c|}{ Facility Evaluation } & 600d & Fair & Poor \\
\hline $\begin{array}{l}\text { Audio Visual Equipment } \\
\text { Lighting } \\
\text { Ventilation } \\
\text { Sound Proofing } \\
\text { Furniture Set Up } \\
\text { Room Cleaniliness } \\
\text { Tea/Coffee }\end{array}$ & $x$ & $\begin{array}{l}x \\
x \\
x \\
x \\
x\end{array}$ & & \multicolumn{3}{|c|}{$\begin{array}{l}\text { Telephone Message } \\
\text { Service } \\
\text { Transportation } \\
\text { Food Services } \\
\text { Hotel Room Lodgingties } \\
\text { Clean Up Services ? } \\
\text { Facility Location } \\
\text { Ancillary Services ? } \\
\text { at Facility }\end{array}$} & & $\begin{array}{l}> \\
2 \\
2\end{array}$ & \\
\hline
\end{tabular}

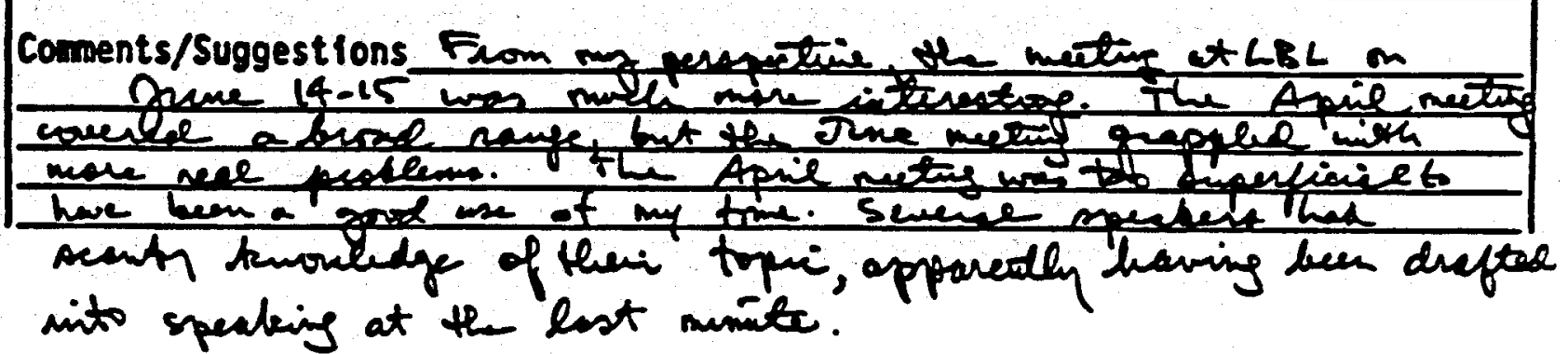


Post-Conference Evaluation Form

U.S. Department of Energy

Annual Geothernal Program Review

Apri1 19-21, 1988

Travelodge at the tharf

San Francisco, CA

INDUSTRY

\begin{tabular}{|c|c|c|c|c|c|c|c|c|c|}
\hline Conference Evaluation & & & & Good & Fair & Poor & Com & ments & \\
\hline $\begin{array}{l}\text { Fulfillment of Conferenc } \\
\text { Appropriateness of Theme } \\
\text { Adequacy of Theme Covera } \\
\text { Research Adequately Desc } \\
\text { Value of R\&D to Industry } \\
\text { Conveyed } \\
\text { Exciting New Technologie } \\
\text { Time Allotted for Questi } \\
\text { Timing of Conference } \\
\text { Locat ion of Conference } \\
\text { Sequence of Events } \\
\text { Effectiveness of Present } \\
\text { Speaker Selection } \\
\text { Audio Visual Materials } \\
\text { Conference Materials Dis } \\
\text { Overall Conference Organ } \\
\text { Effectiveness } \\
\text { Registration Procedures }\end{array}$ & $\begin{array}{l}\text { Objec } \\
\text { e } \\
\text { ibed } \\
\text { clear } \\
\text { Deser } \\
\text { ins } \\
\text { itions } \\
\text { ribut } \\
\text { zatior }\end{array}$ & $\begin{array}{l}\text { ctive: } \\
\text { ry } \\
\text { ribed } \\
\text { ton } \\
\text { to }\end{array}$ & & & & & & & \\
\hline Meeting Room Evaluation & Good & Faị & Poor & Facil & ty Ev & $\frac{1}{\text { aluation }}$ & Good & Fair & Poor \\
\hline $\begin{array}{l}\text { Audio Visual Equipment } \\
\text { Lighting } \\
\text { Ventilation } \\
\text { Sound Proofing } \\
\text { Furniture Set Up } \\
\text { Room Cleanliness } \\
\text { Tea/Coffee }\end{array}$ & $\mathscr{V}$ & $\sqrt{ }$ & & $\begin{array}{l}\text { Telepho } \\
\text { Serv } \\
\text { Transpo } \\
\text { Food Se } \\
\text { Hotel } \\
\text { Clean } \\
\text { Factlit } \\
\text { Anclli } \\
\text { at Fa }\end{array}$ & $\begin{array}{l}\text { one Me } \\
\text { ice } \\
\text { ortati } \\
\text { ervice } \\
\text { Soom Lo } \\
\text { op Ser } \\
\text { oy Loc } \\
\text { iry Se } \\
\text { Icilit }\end{array}$ & $\begin{array}{l}\text { ssage } \\
\text { on } \\
\text { s } \\
\text { odging } \\
\text { vices } \\
\text { ation } \\
\text { rvices } \\
y\end{array}$ & & & \\
\hline
\end{tabular}

Comments/Suggestions 
Post-Conference Evaluation Form

U.S. Department of Energy

Annual Ceothereal Progran Review

April 19-21, 1988

Travelodge at the tharf

INDUSTRY

San Francisco, CA

\begin{tabular}{|c|c|c|c|c|c|c|c|c|c|}
\hline Conference Evaluation & & & & Tood & Fair & Poor & $\operatorname{com}$ & ments & \\
\hline $\begin{array}{l}\text { Fulfillment of Conferenc } \\
\text { Appropriateness of Theme } \\
\text { Adequacy of Theme Covera } \\
\text { Research Adequately Desc } \\
\text { Value of R\&D to Industry } \\
\text { Conveyed } \\
\text { Exciting New Technologie } \\
\text { Time Allotted for Questi } \\
\text { Timing of Conference } \\
\text { Location of Conference } \\
\text { Sequence of Events } \\
\text { Effectiveness of Present } \\
\text { Speaker Selection } \\
\text { Audio Visual Materials } \\
\text { Conference Materials Dis } \\
\text { Overali Conference Organ } \\
\text { Effect iveness } \\
\text { Registration Procedures }\end{array}$ & $\begin{array}{l}\text { Objec } \\
\text { ibed } \\
\text { clear } \\
\text { Deser } \\
\text { ns } \\
\text { tions } \\
\text { ribut } \\
\text { zatior } \\
\text {. }\end{array}$ & $\begin{array}{l}\text { Etives } \\
\text { ribed } \\
\text { ion } \\
\text { nit }\end{array}$ & & $\begin{array}{l}= \\
= \\
= \\
\end{array}$ & $\begin{array}{l}- \\
-\end{array}$ & - & $\begin{array}{l}\text { Haz wa } \\
\text { Spraked } \\
\text { Efficen }\end{array}$ & $-t-t h$ & $\begin{array}{l}\text { spects } \\
\text { dati } \\
\text { as }\end{array}$ \\
\hline Meeting Room Evaluation & Good & Fair & Poor & Facil & ity Ev & aluation & \begin{tabular}{l|l} 
n & $6000 d$
\end{tabular} & Fair & Poor \\
\hline $\begin{array}{l}\text { Audio Visual Equipment } \\
\text { Lighting } \\
\text { Ventilation } \\
\text { Sound Proofing } \\
\text { Furniture Set Up } \\
\text { Room Cleaniliness } \\
\text { Tea/Coffee }\end{array}$ & $r$ & $\begin{array}{l}\simeq \\
-\end{array}$ & & $\begin{array}{c}\text { Telepl } \\
\text { Ser } \\
\text { Trans! } \\
\text { Food } \\
\text { Hotel } \\
\text { Clean } \\
\text { Facll } \\
\text { Ancli } \\
\text { at }\end{array}$ & $\begin{array}{l}\text { one Me } \\
\text { ice } \\
\text { ortati } \\
\text { ervice } \\
\text { Room L } \\
\text { Up Ser } \\
\text { ty Loc } \\
\text { ary Se } \\
\text { acilit }\end{array}$ & $\begin{array}{l}\text { ssage } \\
\text { on } \\
\text { s } \\
\text { odging } \\
\text { vices } \\
\text { ation } \\
\text { rvices } \\
y\end{array}$ & $\begin{array}{c}\text { N/A } \\
\because " \\
\ddot{\prime} \\
\angle\end{array}$ & & \\
\hline
\end{tabular}

Coments/Suggestions Request earliex notification of mext conferresuce - 8.12 weets. 
Post-Conference Evaluation Form

U.S. Department of Energy

Annual Geotheral Progra Review

Apri1 19-21, 1988

Travelodge at the Uharf

San Francisco, CA

INDUSTRY

\begin{tabular}{|c|c|c|c|c|c|c|c|c|c|}
\hline Conference Evaluation & & & & $600 d$ & Fair & Poor & $\operatorname{Cos}$ & wents & \\
\hline $\begin{array}{l}\text { Fulfillment of Conferene } \\
\text { Appropriateness of Theme } \\
\text { Adequacy of Theme Cover } \\
\text { Research Adequately Dese } \\
\text { Value of RQD to Industrj } \\
\text { Conveyed } \\
\text { Exciting New Technologie } \\
\text { Time Aliotted for Quest } \\
\text { Timing of Conference } \\
\text { location of Conference } \\
\text { Sequence of Events } \\
\text { Effectiveness of Present } \\
\text { Speaker Selection } \\
\text { Audio Visual Materials } \\
\text { Conference Materials Dis } \\
\text { Overall Conference Organ } \\
\text { Effectiveness } \\
\text { Registration Procedures }\end{array}$ & $\begin{array}{l}\text { Objec } \\
\text { ibed } \\
\text { Clearl } \\
\text { Deser } \\
\text { ns } \\
\text { tions } \\
\text { ributi } \\
\text { zation }\end{array}$ & $\begin{array}{l}\text { etives } \\
\text { ribed } \\
\text { ion }\end{array}$ & & & & & & & \\
\hline Heeting Room Evaluation & Good & Fair & Poor & Facti & E Ev & aluation & Good & Fair & $\overline{\text { Poor }}$ \\
\hline $\begin{array}{l}\text { Audio Visual Equipment } \\
\text { Lighting } \\
\text { Ventilation } \\
\text { Sound Proofing } \\
\text { Furniture Set Up } \\
\text { Room Cleaniliness } \\
\text { Tea/Coffee }\end{array}$ & & & & $\begin{array}{l}\text { Teleph } \\
\text { Serv } \\
\text { Transp } \\
\text { Food S } \\
\text { Hotel } \\
\text { Clean } \\
\text { Faclli } \\
\text { Ancill } \\
\text { at F }\end{array}$ & $\begin{array}{l}\text { one Me } \\
\text { ice } \\
\text { ortati } \\
\text { ervice } \\
\text { Room L } \\
\text { Up Ser } \\
\text { ty Loc } \\
\text { ary Se } \\
\text { acilit }\end{array}$ & $\begin{array}{l}\text { ssage } \\
\text { on } \\
\text { s } \\
\text { odging } \\
\text { vices } \\
\text { ation } \\
\text { rvices } \\
y\end{array}$ & & & \\
\hline
\end{tabular}

Comments/Suggestions 
Post-Conference Evaluation Form

U.S. Department of Energy

Mnual Ceotheral. Progran Review

April 19-21, 1988

Travelodge at the tharf

San francisco, CA

INDUSTRY

\begin{tabular}{|c|c|c|c|c|c|c|c|c|c|}
\hline Conference Evaluation & & & & 6000 & Faír & Poor & $\cos$ & Wents & \\
\hline $\begin{array}{l}\text { Fulfillment of Conferene } \\
\text { Appropriateness of Theme } \\
\text { Adequacy of Theme Covera } \\
\text { Research Adequately Desc } \\
\text { Value of R\&D to Industry } \\
\text { Conveyed } \\
\text { Exciting New Technologie } \\
\text { Time Aliotted for Questi } \\
\text { Timing of Conference } \\
\text { Location of Conference } \\
\text { Sequence of Events } \\
\text { Effectiveness of Present } \\
\text { Speaker Selection } \\
\text { Audio Visual Materials } \\
\text { Conference Materials Dis } \\
\text { Overall Conference Organ } \\
\text { Effectiveness } \\
\text { Registration Procedures }\end{array}$ & $\begin{array}{l}\text { Objec } \\
\text { e } \\
\text { ibed } \\
\text { clearl } \\
\text { Deser } \\
\text { ns } \\
\text { tions } \\
\text { ributi } \\
\text { zation }\end{array}$ & ives & & & & & & & \\
\hline Heeting Room Evaluation & 600d & Fair & Poor & Facil & ty Ev & Tuation & $600 d$ & Fair & Poor \\
\hline $\begin{array}{l}\text { Audio Visual Equipment } \\
\text { Light ing } \\
\text { Ventilation } \\
\text { Sound Proofing } \\
\text { Furniture Set Up } \\
\text { Room Cleanliness } \\
\text { Tea/Coffee }\end{array}$ & $\stackrel{v}{\sigma}$ & $\sim$ & $V$ & $\begin{array}{l}\text { Teleph } \\
\text { Sery } \\
\text { Transp } \\
\text { Food S } \\
\text { Hotel } \\
\text { Clean } \\
\text { Facili } \\
\text { Ancili } \\
\text { at F }\end{array}$ & $\begin{array}{l}\text { one Me } \\
\text { ice } \\
\text { ortati } \\
\text { ervice } \\
\text { Room L } \\
\text { Up Ser } \\
\text { ty Loc } \\
\text { ary Se } \\
\text { acilit }\end{array}$ & $\begin{array}{l}\text { ssage } \\
\text { on NC } \\
\text { s } \\
\text { odging } \\
\text { vices Ne } \\
\text { ation } \\
\text { rvices NC } \\
y\end{array}$ & $\checkmark$ & $\checkmark$ & \\
\hline
\end{tabular}

Coments/Suggestions 
Post-Conference Evaluation Form

U.S. Department of Energy

Annual Ceothereal Progran Review

April 19-21, 1988

Travelodge at the tharf

San Francisco, CA

INDUSTRY

\begin{tabular}{|c|c|c|c|c|c|c|c|c|c|}
\hline Conference Evaluation & & & & 6ood & TFair & Poor & $\operatorname{com}$ & ments & \\
\hline $\begin{array}{l}\text { Fulfillment of Conferene } \\
\text { Appropriateness of Theme } \\
\text { Adequacy of Theme Covera } \\
\text { Research Adequately Desc } \\
\text { Value of RLD to Industry } \\
\text { Conveyed } \\
\text { Exciting New Technologie } \\
\text { Time Allotted for Questi } \\
\text { Timing of Conference } \\
\text { Location of Conference } \\
\text { Sequence of Events } \\
\text { Effect Iveness of Present } \\
\text { Speaker Selection } \\
\text { Audio Visual Materials } \\
\text { Conference Materials Dis } \\
\text { Overall Conference Organ } \\
\text { Effectiveness } \\
\text { Registration Procedures }\end{array}$ & $\begin{array}{l}\text { Objec } \\
\text { ibed } \\
\text { clearl } \\
\text { Deser } \\
\text { ns } \\
\text { tions } \\
\text { ribution } \\
\text { zation }\end{array}$ & $\begin{array}{l}\text { etives } \\
\text { Iy } \\
\text { ribed } \\
\\
\text { ion } \\
\text { ? }\end{array}$ & & $\begin{array}{l}x \\
x \\
x \\
x \\
x \\
\stackrel{x}{x} \\
\dot{x} \\
x \\
x\end{array}$ & $\begin{array}{l}x \\
x\end{array}$ & $x$ & $\begin{array}{l}\text { Parbapes } \\
\text { of walue }\end{array}$ & $\begin{array}{l}\text { ed ch } \\
\text { e. }\end{array}$ & body \\
\hline Meeting Room Evaluation & Good & Fair & Poor & Facil & ity Ev & aluation & $n$ 600d & Fair & Poor \\
\hline $\begin{array}{l}\text { Audio Visual Equipment } \\
\text { Lighting } \\
\text { Vent ilation } \\
\text { Sound Proofing } \\
\text { Furniture Set Up } \\
\text { Room Cleani iness } \\
\text { Tea/Coffee }\end{array}$ & $\begin{array}{l}x \\
x \\
x \\
y \\
y \\
y\end{array}$ & & & $\begin{array}{l}\text { Teleph } \\
\text { Serv } \\
\text { Transp } \\
\text { Food S } \\
\text { Hotel } \\
\text { clean } \\
\text { Facil } \\
\text { Ancill } \\
\text { at F }\end{array}$ & $\begin{array}{l}\text { one Me } \\
\text { ice } \\
\text { ortati } \\
\text { ervice } \\
\text { Room L } \\
\text { Up Ser } \\
\text { ty Loc } \\
\text { ary Se } \\
\text { acilit }\end{array}$ & $\begin{array}{l}\text { ssage } \\
\text { on } \\
\text { s } \\
\text { odging } \\
\text { vices } \\
\text { ation } \\
\text { rvices } \\
y\end{array}$ & $\begin{array}{l}x \\
y \\
x \\
x \\
x\end{array}$ & $x$ & \\
\hline
\end{tabular}

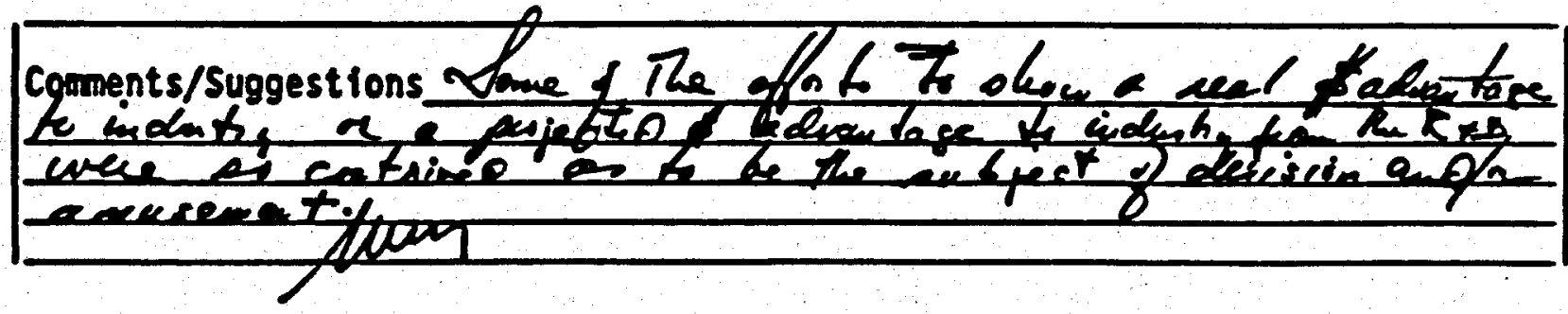


Post-Conference Evaluation Form

U.S. Department of Energy

Annual Geotheral Progran Review

April 19-21, 1988

Travelodge at the tharf

San Francisco, CA

INDUSTRY

\begin{tabular}{|c|c|c|c|c|c|c|c|c|c|}
\hline \multicolumn{4}{|l|}{ Conference Evaluation } & $600 d$ & Trair & Poor & \multicolumn{3}{|c|}{ Coments } \\
\hline \multicolumn{4}{|c|}{$\begin{array}{l}\text { Fulfillment of Conference Objectives } \\
\text { Appropriateness of Theme } \\
\text { Adequacy of Theme Coverage } \\
\text { Research Adequately Described } \\
\text { Value of R\&D to Industry Clearly } \\
\text { Conveyed } \\
\text { Exciting New Technologies Described } \\
\text { TTime Aliotted for Questions } \\
\text { Timing of Conference } \\
\text { Location of Conference } \\
\text { Sequence of Events } \\
\text { Effectiveness of Presentations } \\
\text { Speaker Selection } \\
\text { Audio Visual Materials } \\
\text { Conference Materials Distribution } \\
\text { Overali Conference Organization } \\
\text { Effectiveness } \\
\text { Registration Procedures }\end{array}$} & $\begin{array}{l}x \\
x \\
x \\
x \\
x \\
x \\
x \\
x \\
x \\
x \\
x\end{array}$ & $\begin{array}{l}x \\
\dot{x} \\
\dot{x} \\
x\end{array}$ & & \multicolumn{3}{|c|}{ 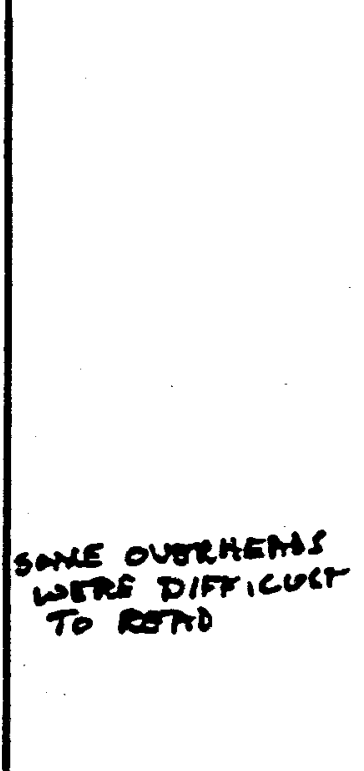 } \\
\hline Heeting Room Evaluation & Good & Fair & Poor & \multicolumn{3}{|c|}{ Facility Evaluation } & 6000 & Fair & Poor \\
\hline $\begin{array}{l}\text { Audio Visual Equipment } \\
\text { Lighting } \\
\text { Vent llation } \\
\text { Sound Proofing } \\
\text { Furniture Set Up } \\
\text { Room Cleani iness } \\
\text { Tea/Coffee }\end{array}$ & $\begin{array}{l}x \\
x \\
x \\
x \\
x \\
x \\
\dot{x} \\
x\end{array}$ & & & \multicolumn{3}{|c|}{$\begin{array}{l}\text { Telephone Message } \\
\text { Service } \\
\text { Transportation } \\
\text { Food Services } \\
\text { Hotel Room Lodging } \\
\text { clean Up Services } \\
\text { Facility Location } \\
\text { Ancilliary Services } \\
\text { at Facility }\end{array}$} & mat & $\mid \begin{array}{c}0 s=0 \\
x \\
x \\
0 x-8 \\
x \\
x\end{array}$ & \\
\hline
\end{tabular}

\section{Comments/Suggestions}


Post-Conference Evaluation Form

U.S. Department of Energy

Annual Geothermal Progran Review

April 19-21, 1988

Travelodge at the tharf

INDUSTRY

San Francisco, CA

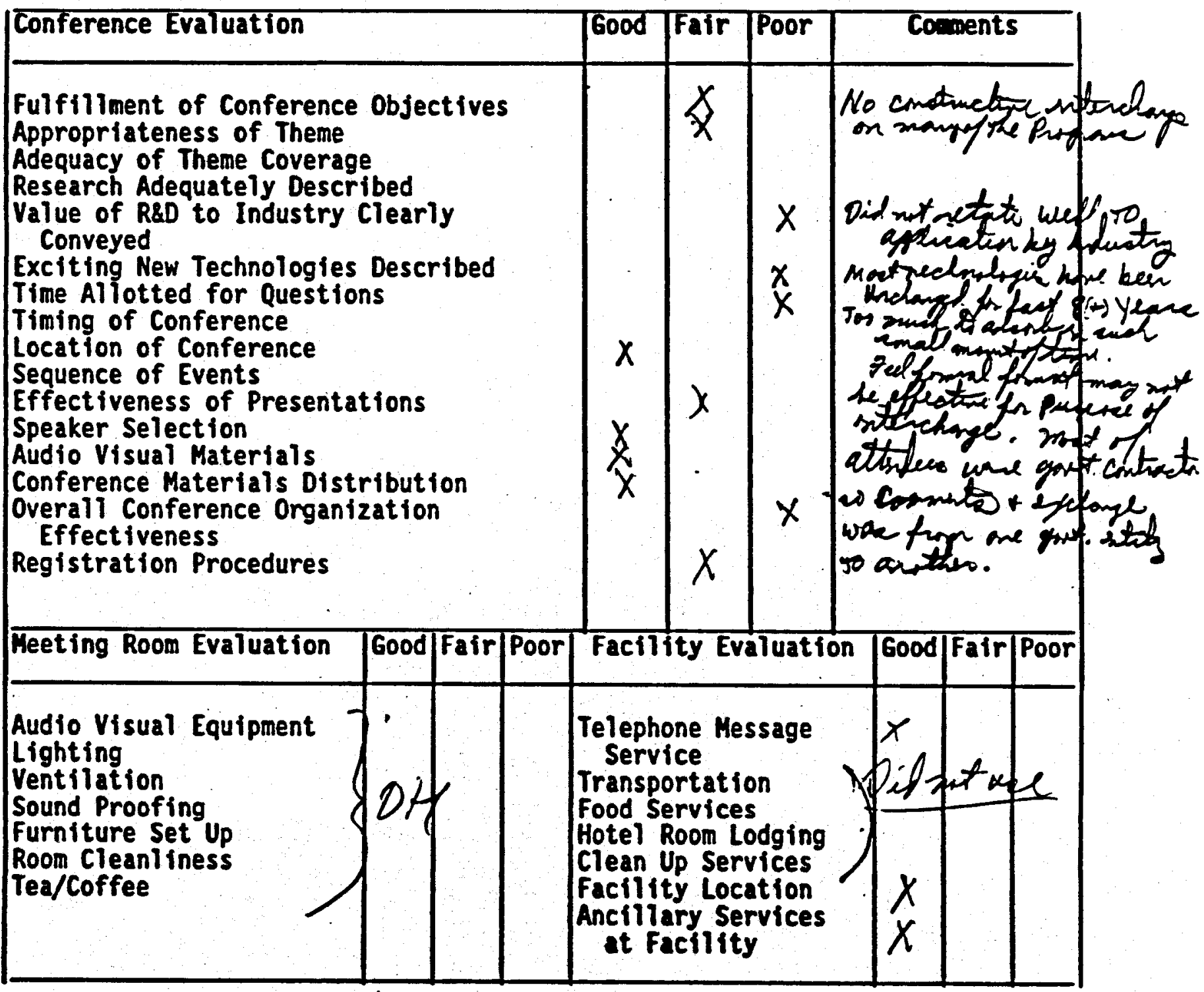

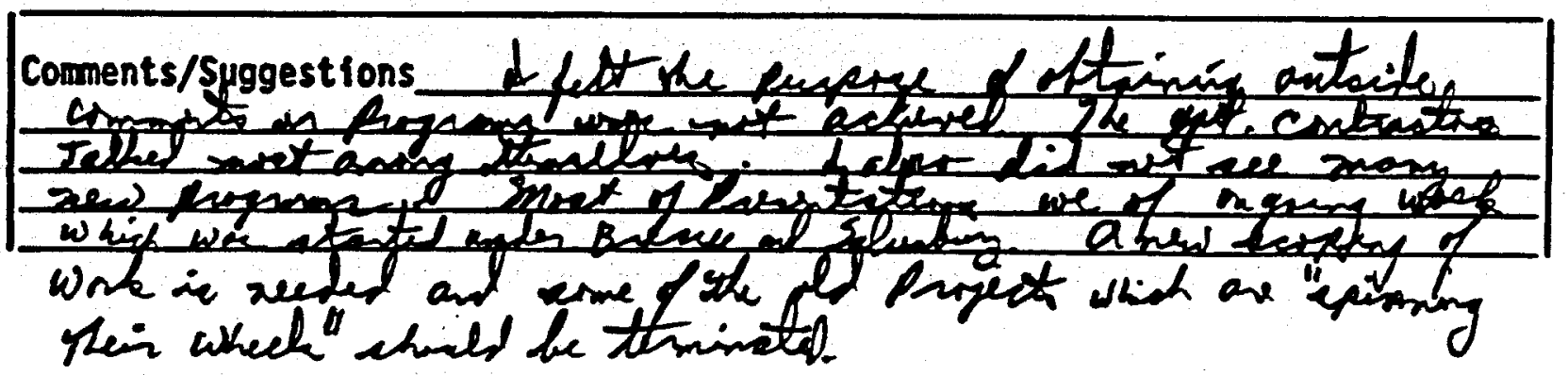


Post-Conference Evaluation Form

U.S. Departwent of Energy

Annual Geotheral Progra Review

Apri1 19-21, 1988

Travelodge at the tharf

San Francisco, CA

INDUSTRY

\begin{tabular}{|c|c|c|c|c|c|c|c|c|c|}
\hline Conference Evaluation & & & & Good & Fair & Poor & & ments & \\
\hline $\begin{array}{l}\text { Fulfillment of Conferenc } \\
\text { Appropriateness of Theme } \\
\text { Adequacy of Theme Covera } \\
\text { Research Adequately Desc } \\
\text { Value of R\&D to Industry } \\
\text { Conveyed } \\
\text { Exciting New Technologie } \\
\text { Time Allotted for Questi } \\
\text { Timing of Conference } \\
\text { Location of Conference } \\
\text { Sequence of Events } \\
\text { Effectiveness of Present } \\
\text { Speaker Selection } \\
\text { Audio Visual Materials } \\
\text { Conference Materials Dis } \\
\text { Overali Conference Organ } \\
\text { Effectiveness } \\
\text { Registration Procedures }\end{array}$ & $\begin{array}{l}\text { Objec } \\
\text { ibed } \\
\text { clearl } \\
\text { Deser } \\
\text { ns } \\
\text { tions } \\
\text { ributi } \\
\text { zation }\end{array}$ & $\begin{array}{l}\text { etives } \\
\text { ribed } \\
\text { ion }\end{array}$ & & & & & 1 & $\begin{array}{l}\text { rulel } \\
\text { piefn } \\
\text { iff } \\
\text { mal }\end{array}$ & $\begin{array}{l}\text { and } \\
\text { on } \\
\text { chef }\end{array}$ \\
\hline Heeting Room Evaluation & Good & Fair & Poor & Facil & tity Ev & $\frac{1}{\text { Tuation }}$ & 6000 & Fair & Poor \\
\hline $\begin{array}{l}\text { Audio Visual Equipment } \\
\text { Lighting } \\
\text { Vent liation } \\
\text { Sound Proofing } \\
\text { Furniture Set Up } \\
\text { Room Cleanliness } \\
\text { Tea/Coffee }\end{array}$ & & & & $\begin{array}{c}\text { Teleph } \\
\text { Serv } \\
\text { Transp } \\
\text { Food S } \\
\text { Hotel } \\
\text { Clean } \\
\text { Facili } \\
\text { Ancili } \\
\text { at F }\end{array}$ & $\begin{array}{l}\text { one Me } \\
\text { ice } \\
\text { ortati } \\
\text { ervice } \\
\text { Room L } \\
\text { Up Ser } \\
\text { ty Loc } \\
\text { ary Se }\end{array}$ & $\begin{array}{l}\text { sage } \\
n \\
\text { dging } \\
\text { ices } \\
\text { tion } \\
\text { vices }\end{array}$ & & & \\
\hline
\end{tabular}

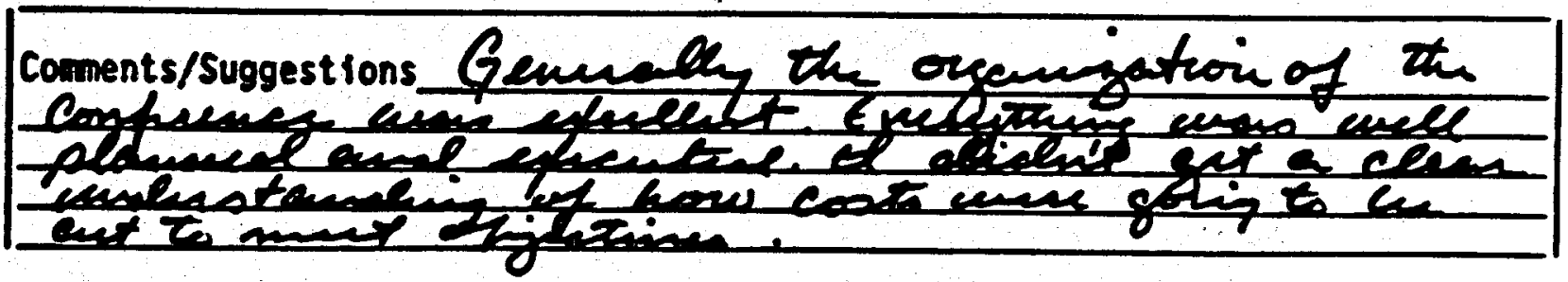


Post-Conference Evaluation For

U.S. Department of Energy

Annual Geotheral progran Review

April 19-21, 1988

Travelodge at the tharf

San Franciseo, CA

INDUSTRY

\begin{tabular}{|c|c|c|c|c|c|c|c|c|c|}
\hline \multicolumn{4}{|l|}{ Conference Evaluation } & 6000 & Tfair & Poor & & iments & \\
\hline \multicolumn{4}{|c|}{$\begin{array}{l}\text { Fulfillment of Conference Objectives } \\
\text { Appropriateness of Theme } \\
\text { Adequacy of Theme Coverage } \\
\text { Research Adequately Described } \\
\text { Value of R\&D to Industry. Clearly } \\
\text { Conveyed } \\
\text { Exciting New Technologies Described } \\
\text { Time Aliotted for Questions } \\
\text { Timing of Conference } \\
\text { Location of Conference } \\
\text { Sequence of Events } \\
\text { Effectiveness of Presentations } \\
\text { Speaker Selection } \\
\text { Audio Visual Materials } \\
\text { Conference Materials Distribution } \\
\text { Overall Conference Organization } \\
\text { Effectiveness } \\
\text { Registration Procedures }\end{array}$} & $\begin{array}{l}\mathbf{X} \\
\mathbf{X} \\
\mathbf{x} \\
\mathrm{X} \\
\mathrm{X} \\
\mathrm{X} \\
\mathrm{x}\end{array}$ & $\mathbf{x}$ & $x$ & $\begin{array}{l}\text { See le } \\
\text { No pret } \\
\text { for } t l\end{array}$ & $\begin{array}{l}\text { prin } \\
\text { he pi }\end{array}$ & $\begin{array}{l}\text { ts } \\
\text { aper }\end{array}$ \\
\hline Meeting Room Evaluation & Good & Faí & Poor & \multicolumn{3}{|c|}{ Facility Evaluation } & $n|600 d|$ & Fair & Poor \\
\hline $\begin{array}{l}\text { Audio Visual Equipment } \\
\text { Light ing } \\
\text { Ventilation } \\
\text { Sound Proofing } \\
\text { Furniture Set Up } \\
\text { Room Cleanliness } \\
\text { Tea/Coffee }\end{array}$ & & $\begin{array}{l}x \\
x \\
x \\
x \\
x \\
x \\
x\end{array}$ & & \multicolumn{3}{|c|}{$\begin{array}{l}\text { Telephone Message } \\
\text { Service } \\
\text { Transportation } \\
\text { Food Services } \\
\text { Hotel Room Lodging } \\
\text { Clean Up Services } \\
\text { Facllity Location } \\
\text { Ancillary Services } \\
\text { at Facility }\end{array}$} & & $\begin{array}{l}\mathrm{X} \\
\mathrm{X} \\
\mathrm{X} \\
\mathrm{X} \\
\mathrm{X}\end{array}$ & \\
\hline
\end{tabular}

Coaments/Suggestions 
July 5,1988

Ms. Carole Beeman

Meridian Corporation

Suite 400

4300 king street

Alexandria, virginia 22302

Dear Ms. Beeman:

As requested by Mr. Ralph E. Burr in his letter of June 16, 1988 , I am enclosing the Post-Conference Evaluation Form for Geothermal Program Review VI, April 19-21, 1988. In addition, I would like to offer the following comments:

1. The first two days of the review were well structured. The morning session of the third day featured an industry round table sponsored by the National Geothermal Association, a newly formed organization with interest in trade, finance, lobbying, etc. The aftermoon session again reverted to DOE geothermal program, but the papers consisted of a potpourri on various unrelated subjects. I think that stretching out the meeting from $2-1 / 2$ days to 3 days was a mistake. Sandwiching the National Geothermal Association round table into the DOE program to keep the largely research-oriented attendees as a captive audience should never have been attempted.

2. Although the quality of the research appeared to be reasonably good, the titles of some papers were rather ludicrous. Here are some examples:

Title

Reducing Long-Term Reservoir Performance Uncertainty

Understanding Reservoir Dynamics
Actual Topic

Geothermal reservoir engineering

Tracer test interpretation

Fortunately, this nonsense of bullding up the Image of the actual research by using some eye-catching phrases was only inited to the papers in the hydrothermal research sessions. More descriptive titles, as they should be, were used in other sessions. Was the pecullar 
Ms. Carole Beeman

July 5, 1988

Page 2

but apparently concerted practice in the hydrothermal research sessions due to an edict imposed by the subprogram manager? I suggest that these titles, and some other similar titles, be revised before the final printing of the proceedings.

sincerely, 
Post-Conference Evaluation Form

U.S. Department of Energy

Annual Geothermal Program Review

Apri1 19-21, 1988

Travelodge at the Wharf

San Francisco, CA

INDUSTRY

\begin{tabular}{|c|c|c|c|c|c|c|c|c|c|c|}
\hline \multicolumn{4}{|l|}{ Conference Evaluation } & Good & Fair & Poor & \multicolumn{3}{|c|}{ Comments } & \\
\hline \multicolumn{4}{|c|}{$\begin{array}{l}\text { Fulfillment of Conference Objectives } \\
\text { Appropriateness of Theme } \\
\text { Adequacy of Theme Coverage } \\
\text { Research Adequately Described } \\
\text { Value of R\&D to Industry Clearly } \\
\text { Conveyed } \\
\text { Exciting New Technologies Described } \\
\text { Time Allotted for Questions } \\
\text { Timing of Conference } \\
\text { Location of Conference } \\
\text { Sequence of Events } \\
\text { Effectiveness of Presentations } \\
\text { Speaker Selection } \\
\text { Audio Visual Materials } \\
\text { Conference Materials Distribution } \\
\text { Overall Conference Organization } \\
\text { Effectiveness } \\
\text { Registration Procedures }\end{array}$} & $\begin{array}{l}\begin{array}{l}x \\
x \\
x\end{array} \\
x \\
x \\
x \\
x \\
x\end{array}$ & $x$ & & \multicolumn{3}{|c|}{$\begin{array}{l}\text { INSUFFICIENT } \\
\text { TO SPEAKERS }\end{array}$} & $\begin{array}{l}\text { finE } \\
\text { fAKERS }\end{array}$ \\
\hline Meeting Room Evaluation & Good & Fair & Poor & \multicolumn{3}{|c|}{ Facility Evaluation } & $n \mid$ Good & Fair & Poor & \\
\hline $\begin{array}{l}\text { Audio Visual Equipment } \\
\text { Lighting } \\
\text { Ventilation } \\
\text { Sound Proofing } \\
\text { Furniture Set Up } \\
\text { Room Cleanliness } \\
\text { Tea/Coffee }\end{array}$ & $\begin{array}{l}x \\
x \\
x\end{array}$ & $x$ & $x$ & \multicolumn{3}{|c|}{$\begin{array}{l}\text { Telephone Message } \\
\text { Service } \\
\text { Transportation } \\
\text { Food Services } \\
\text { Hotel Room Lodging } \\
\text { Clean Up Services } \\
\text { Facility Location } \\
\text { Ancillary Services } \\
\text { at Facility }\end{array}$} & & $\begin{array}{l}x \\
x \\
x \\
x \\
x\end{array}$ & $x$ & \\
\hline
\end{tabular}

Comments/Suggestions - $z$ HAVE APPRECiATES, iN PARTiCULAR, THE EFFORT BeEING MADE BY THE DOE PROGRAh TO QUAMTIFY THE RISK OF HAIN ACTIVITIES, TO EVALUATE POSSIBLE REDUCTION OF COST OF EACA ACTIVITY AND To ASSESSTKE OVERALL IAPACT OF THE LIFE-CYCLE COST OF POWER GENE: RATIDN FROH HYJLOTHERMAL ITHEHS.

- EFFORT SHOULD CONTINUE IN THIS SECEOR, AIMES AT iMPROVING hODELILATION ANS THE INCISENCE OF THE VARIDUS PARATIETRES. 
Post-Conference Evaluation Form

U.S. Department of Energy

Annual Geothermal Program Review

Apri1 19-21, 1988

Travelodge at the tharf

San Francisco, CA

NATIONAL LAB

\begin{tabular}{|c|c|c|c|c|c|c|c|c|c|}
\hline Conference Evaluation & & & & Good & Fair & Poor & Com & ments & \\
\hline $\begin{array}{l}\text { Fulfillment of Conferenc } \\
\text { Appropriateness of Theme } \\
\text { Adequacy of Theme Covera } \\
\text { Research Adequately Desc } \\
\text { Value of R\&D to Industry } \\
\text { Conveyed }\end{array}$ & $\begin{array}{l}\text { objec } \\
\text { ibed } \\
\text { Clearl }\end{array}$ & y & & & $\begin{array}{l}x \\
x \\
x\end{array}$ & $\begin{array}{l}x \\
x\end{array}$ & & & \\
\hline $\begin{array}{l}\text { Exciting New Technologie } \\
\text { Time Allotted for Questi } \\
\text { Timing of Conference } \\
\text { Location of Conference } \\
\text { Sequence of Events }\end{array}$ & $\begin{array}{l}\text { Descr } \\
\text { ns }\end{array}$ & & & $\begin{array}{l}x \\
x \\
x \\
x\end{array}$ & $\bar{x}$ & & & & \\
\hline $\begin{array}{l}\text { Effectiveness of Present } \\
\text { Speaker Selection } \\
\text { Audio Visual Materiais } \\
\text { Confererice Materiais Dis } \\
\text { Overall Conference Organ } \\
\text { Effectiveness }\end{array}$ & $\begin{array}{l}\text { Eions } \\
\text { ributi } \\
\text { zation }\end{array}$ & & & $\begin{array}{l}x \\
x \\
x\end{array}$ & $\begin{array}{l}x \\
x\end{array}$ & & & & \\
\hline Registration Procedures & & & & $x$ & & & & & \\
\hline Meeting Room Evaluation & Good & Fair & Poor & Facil & ity Ev & aTuation & Good & Fair & Poor \\
\hline $\begin{array}{l}\text { Audio Visual Equipment } \\
\text { Lighting } \\
\text { Ventilation } \\
\text { Sound Proofing } \\
\text { Furniture Set Up } \\
\text { Room Cleanliness } \\
\text { Tea/Coffee }\end{array}$ & $\begin{array}{l}x \\
x \\
x \\
x\end{array}$ & $x^{x}$ & $x$ & $\begin{array}{c}\text { Teleph } \\
\text { Serv } \\
\text { Transp } \\
\text { Food S } \\
\text { Hotel } \\
\text { Clean } \\
\text { Facili } \\
\text { Ancil } \\
\text { at F }\end{array}$ & $\begin{array}{l}\text { one Me } \\
\text { ice } \\
\text { ortati } \\
\text { ervice } \\
\text { Room L } \\
\text { Up Ser } \\
\text { ty Loc } \\
\text { ary Se } \\
\text { acilit }\end{array}$ & $\begin{array}{l}\text { ssage } \\
\text { on } \\
\text { s } \\
\text { odging } \\
\text { vices } \\
\text { ation } \\
\text { rvices } \\
y\end{array}$ & $\begin{array}{l}x \\
x \\
x \\
x \\
x \\
x \\
x\end{array}$ & & \\
\hline
\end{tabular}

Comments/Suggestions Shoe/d try to host meetimgs at hetels within per diem. The managenengt and nogrommathe enplias is wes noy totelly inthed to indenty and ss more oxpeopert an a doE merting. 
Post-Conference Evaluation For

U.S. Department of Energy

Banul Ceothermal Progra Review

April 19-21, 1983

Travelodge at the tharf

San Francisco, $\mathrm{CA}$

NATIONAL LAB

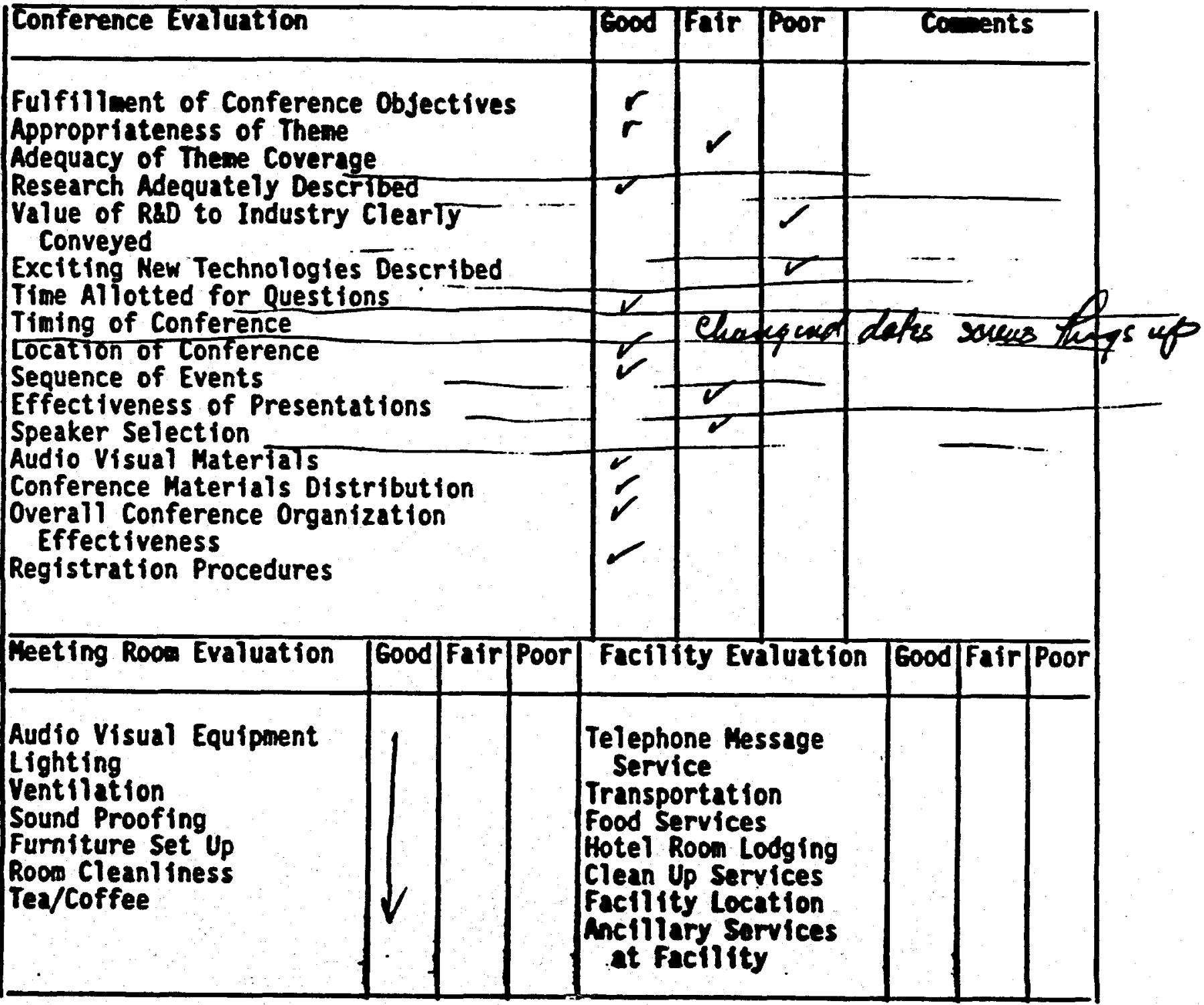

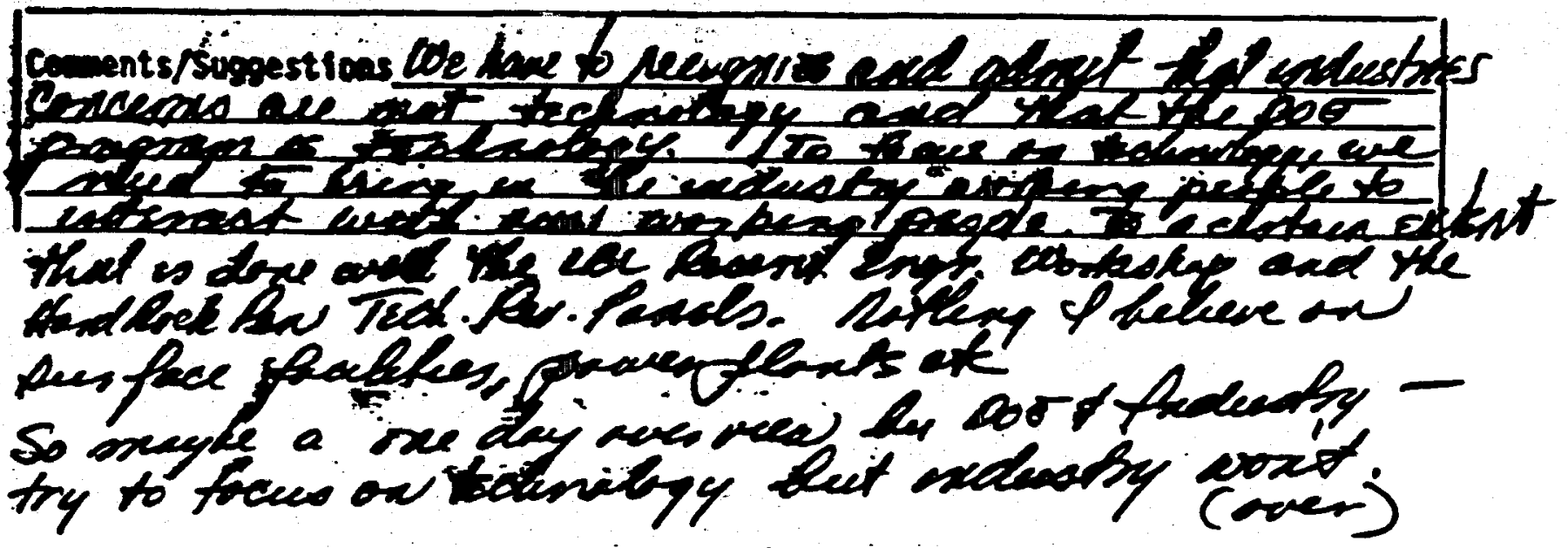


Theor perkaps oxe day en if parallel scosuns -

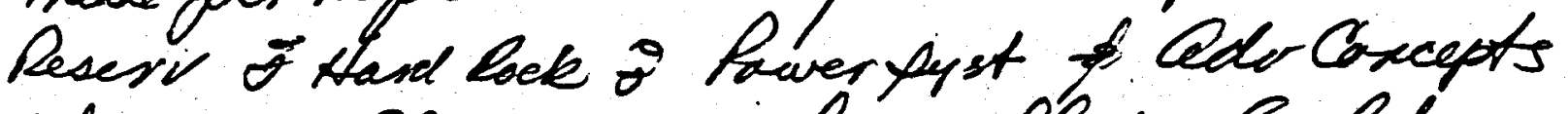

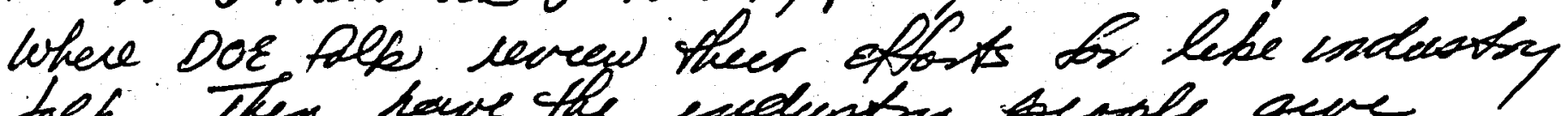
tolk. Then have the eselesstry besple quve

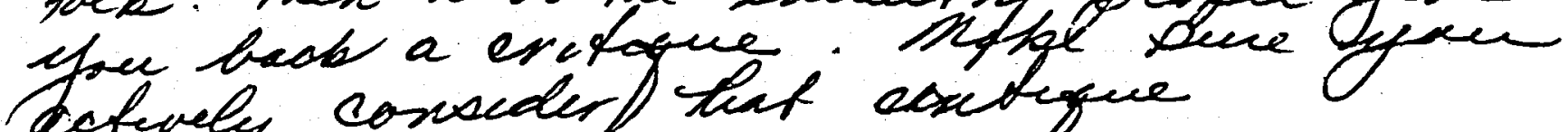
Actively conscderf that exitygue

Pertips the endercdual revecurs ane vepanat of doxic at the excosteng mestexys, or muybe GRC. Thew of your levlew, habe the crolestry reports

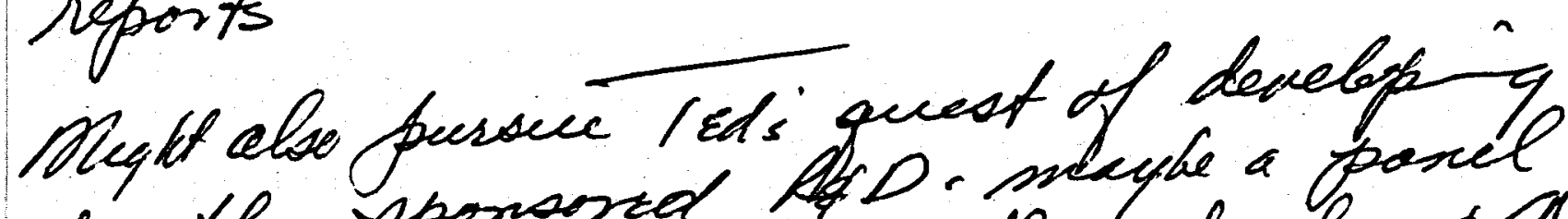
frently sponsoned AsD. meype a parel or whatars on GDO, 6TO, other acturtees Meeds.

F-32 
Post-Conference Evaluation Form

U.S. Department of Energy

Aneal Coothereal Progrea Review

Apri1 19-21, 1988

Travelodge at the tharf

San Francisco, Ca

NATIONAL LAB

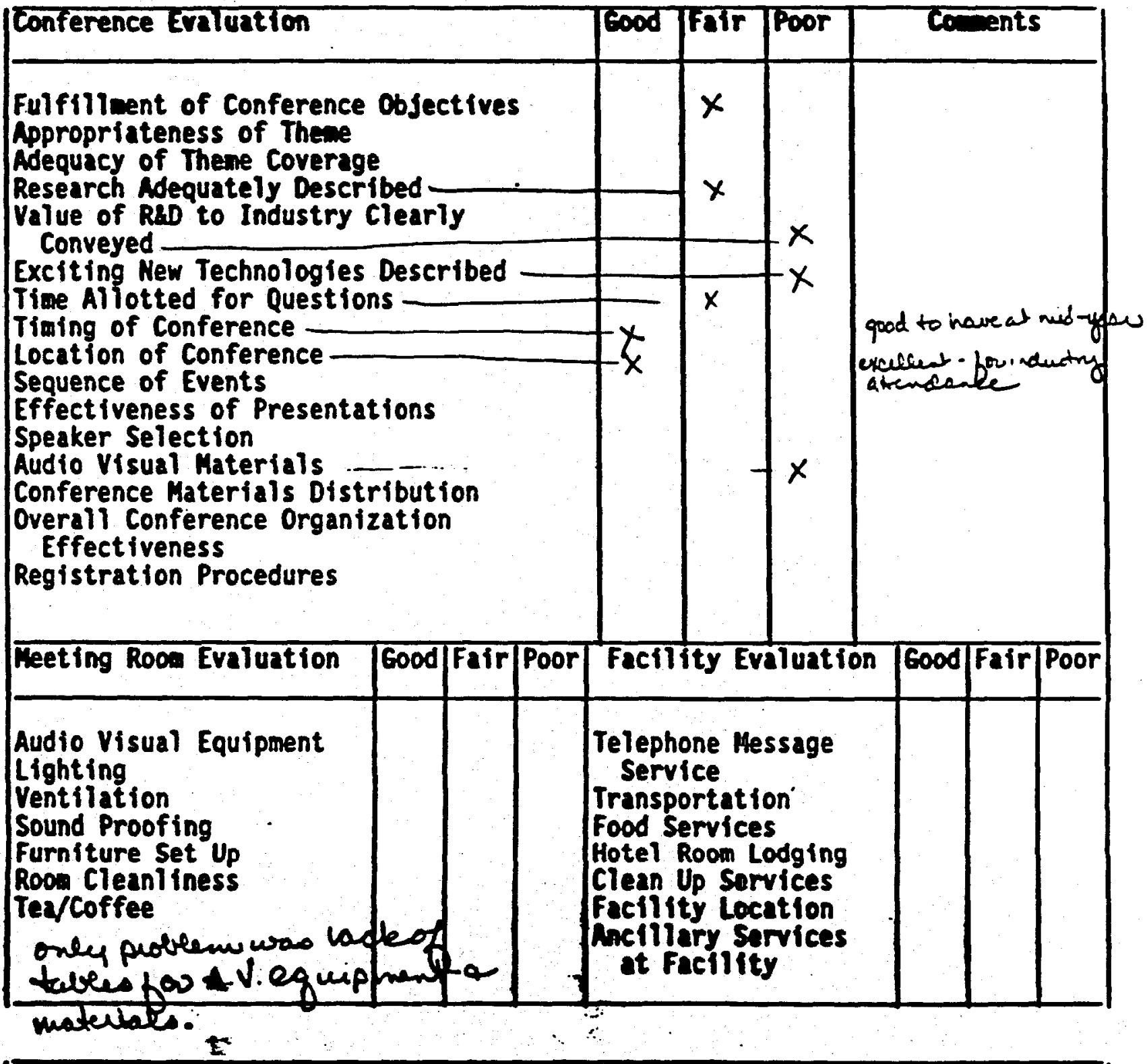

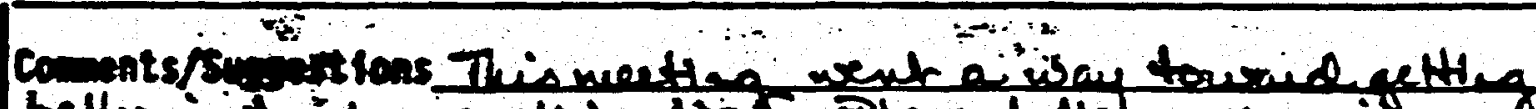

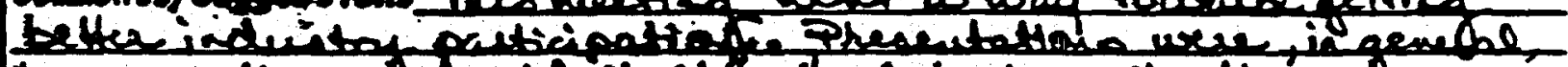

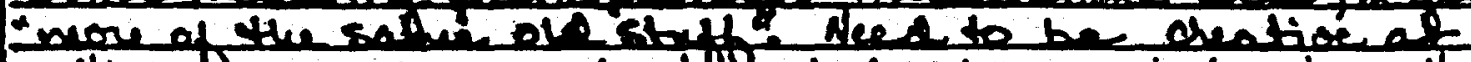

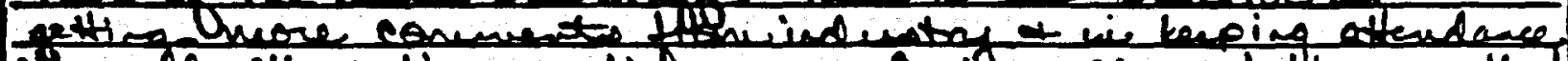

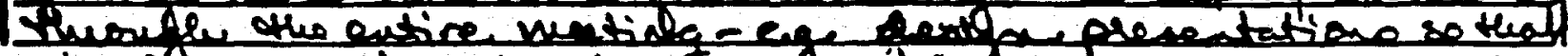

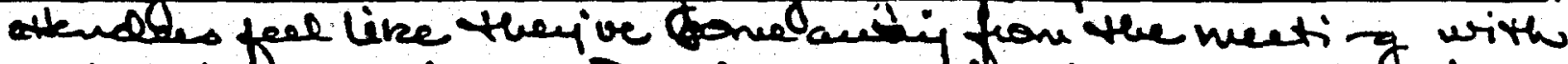
usefue informatiou. Prostde more effective wrey to get inpur ou goces objectives - thinge that are neaning fue to them, not the empty "mothenhood rapplepie" stuff presented in the bue boole. Either publish procondings within $1-2$ mos. of macti 7 or don't bothes. 
Post-Conference Evaluation Form

U.S. Department of Energy

Annual Geothernal Progran Review

April 19-21, 1988

Travelodge at the tharf

NATIONAL LAB

San Francisco, CA

\begin{tabular}{|c|c|c|c|c|c|c|c|c|c|}
\hline \multicolumn{4}{|l|}{ Conference Evaluation } & Good & TFair & Poor & \multicolumn{3}{|c|}{ Coments } \\
\hline \multicolumn{4}{|c|}{$\begin{array}{l}\text { Fulfillment of Conference Objectives } \\
\text { Appropriateness of Theme } \\
\text { Adequacy of Theme Coverage } \\
\text { Research Adequately Described } \\
\text { Value of R\&D to Industry Clearly } \\
\text { Conveyed } \\
\text { Excit ing New Technologies Described } \\
\text { Time Aliotted for Questions } \\
\text { Timing of Conference } \\
\text { Location of Conference } \\
\text { Sequence of Events } \\
\text { Effectiveness of Presentations } \\
\text { Speaker Selection } \\
\text { Audio Visual Materials } \\
\text { Conference Materials Distribution } \\
\text { Overali Conference Organization } \\
\text { Effectiveness } \\
\text { Registration Procedures }\end{array}$} & $\begin{array}{l}v \\
v \\
v \\
v \\
v \\
v \\
v \\
v \\
v \\
v\end{array}$ & & & \multicolumn{3}{|c|}{ Same slookk bo updeted } \\
\hline Heeting Room Evaluation & Good & Fair & Poor & \multicolumn{3}{|c|}{ Facility Evaluation } & |Good & Fair & Poor \\
\hline $\begin{array}{l}\text { Audio Visual Equipment } \\
\text { Lighting } \\
\text { Ventilation } \\
\text { Sound Proofing } \\
\text { Furniture Set Up } \\
\text { Room Cleaniliness } \\
\text { Tea/Coffee }\end{array}$ & $\begin{array}{l}r \\
v \\
v \\
v\end{array}$ & $r$ & & \multicolumn{3}{|c|}{$\begin{array}{l}\text { Telephone Message } \\
\text { Service } \\
\text { Transportation } \\
\text { Food Services } \\
\text { Hotel Room Lodging } \\
\text { clean Up Services } \\
\text { Facility Location } \\
\text { Ancillary Services } \\
\text { at Facility }\end{array}$} & $\begin{array}{l}V \\
V \\
V \\
V \\
V \\
V\end{array}$ & & \\
\hline
\end{tabular}

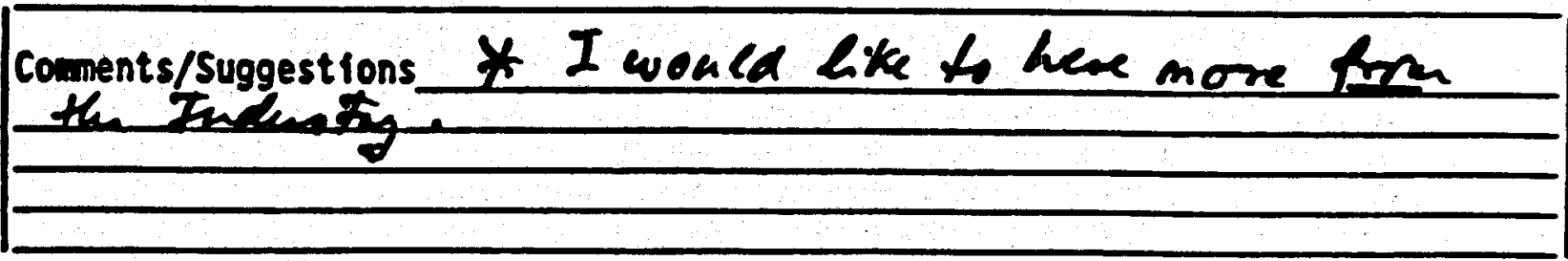


Post-Conference Evaluation Form

U.S. Department of Energy

Annual Geotheral Progran Review

Aprit 19-21, 1988 NATIONAL LAB

Travelodge at the tharf

San Francisco, CA

\begin{tabular}{|c|c|c|c|c|c|c|c|c|c|}
\hline Conference Evaluation & & & & $600 d$ & Fair & Poor & $\cos$ & ments & \\
\hline $\begin{array}{l}\text { Fulfillment of Conferenc } \\
\text { Appropriateness of Theme } \\
\text { Adequacy of Theme Covera } \\
\text { Research Adequately Desc } \\
\text { Value of R\&D to Industry } \\
\text { Conveyed } \\
\text { Exciting New Technologie } \\
\text { Time Aliotted for Questi } \\
\text { Timing of Conference } \\
\text { Location of Conference } \\
\text { Sequence of Events } \\
\text { Effectiveness of Present } \\
\text { Speaker Selection } \\
\text { Audio Visual Materials } \\
\text { Conference Materiais Dis } \\
\text { Overall Conference Organ } \\
\text { Effectiveness } \\
\text { Registration Procedures }\end{array}$ & $\begin{array}{l}\text { Objec } \\
\text { ibed } \\
\text { Clearl } \\
\text { Descr } \\
\text { ns } \\
\text { tions } \\
\text { ributi } \\
\text { zation }\end{array}$ & itives & & & & & & & \\
\hline Meeting Room Evaluation & Good & Fair & Poor & Facil & ity Ex & aluation & Good & $\overline{\text { Fair }}$ & Poor \\
\hline $\begin{array}{l}\text { Audio Visual Equipment } \\
\text { Lighting } \\
\text { Ventilation } \\
\text { Sound Proofing } \\
\text { Furniture Set Up } \\
\text { Room Cleanifiness } \\
\text { Tea/Coffee }\end{array}$ & & $\frac{2}{2}$ & & $\begin{array}{c}\text { Teleph } \\
\text { Serv } \\
\text { Transp } \\
\text { Food } 5 \\
\text { Hotel } \\
\text { Clean } \\
\text { Facil } \\
\text { Ancil } \\
\text { at F }\end{array}$ & $\begin{array}{l}\text { one Me } \\
\text { ice } \\
\text { ortat } \\
\text { ervice } \\
\text { Room I } \\
\text { Up Ser } \\
\text { ty Loc } \\
\text { ary Se }\end{array}$ & $\begin{array}{l}\text { sage } \\
\text { in } \\
\text { dging } \\
\text { ices } \\
\text { ition } \\
\text { vices }\end{array}$ & & & \\
\hline
\end{tabular}

Comments/Suggestions 
Post-Conference Evaluation Form

U.S. Departiment of Energy

Annual Geotheral Progran Review

NATIONAL LAB

Apri1 19-21, 1988

Travelodge at the tharf

San Francisco, CA

\begin{tabular}{|c|c|c|c|c|c|c|c|c|c|}
\hline Conference Evaluation & & & & 6ood & Fair & Poor & & ments & \\
\hline $\begin{array}{l}\text { Fulfillment of Conferene } \\
\text { Appropriateness of Theme } \\
\text { Adequacy of Theme Covera } \\
\text { Research Adequately Desc } \\
\text { Value of RLD to Industry } \\
\text { Conveyed } \\
\text { Exciting New Technologie } \\
\text { Time Allotted for Questi } \\
\text { Timing of Conference } \\
\text { Socation of Conference } \\
\text { Sequence of Events } \\
\text { Effectiveness of Present } \\
\text { Speaker Selection } \\
\text { Audio Visual Materials } \\
\text { Conference Materiais Dis } \\
\text { Overall Conference Organ } \\
\text { Effectiveness } \\
\text { Registration Procedures }\end{array}$ & $\begin{array}{l}\text { Objec } \\
\text { ibed } \\
\text { Glear } \\
\text { Deser } \\
\text { is } \\
\text { ions } \\
\text { ibut } \\
\text { catior }\end{array}$ & $\begin{array}{l}\text { ctives } \\
\text { ribed } \\
\text { ion } \\
\text { n }\end{array}$ & & & & & & • & \\
\hline Heeting Room Evaluation & Good & Fair & Poor & Facti & ty Ev & Iuation & 6ood & Fair & $\overline{\text { Poor }}$ \\
\hline $\begin{array}{l}\text { Audio Visual Equipment } \\
\text { Lighting } \\
\text { Ventilation } \\
\text { Sound Proofing } \\
\text { Furniture Set Up } \\
\text { Room Cleani iness } \\
\text { Tea/Coffee }\end{array}$ & & & & $\begin{array}{c}\text { Teleph } \\
\text { Serv } \\
\text { Transp } \\
\text { food S } \\
\text { Hotel } \\
\text { Clean } \\
\text { Factil } \\
\text { Ancill } \\
\text { at F }\end{array}$ & $\begin{array}{l}\text { one Me } \\
\text { ice } \\
\text { ortati } \\
\text { ervice } \\
\text { Room L } \\
\text { Up Ser } \\
\text { ty Loc } \\
\text { ary Se } \\
\text { acilit }\end{array}$ & $\begin{array}{l}\text { ssage } \\
\text { on } \\
\text { s } \\
\text { odging } \\
\text { vices } \\
\text { ition } \\
\text { rvices } \\
y\end{array}$ & & & \\
\hline
\end{tabular}

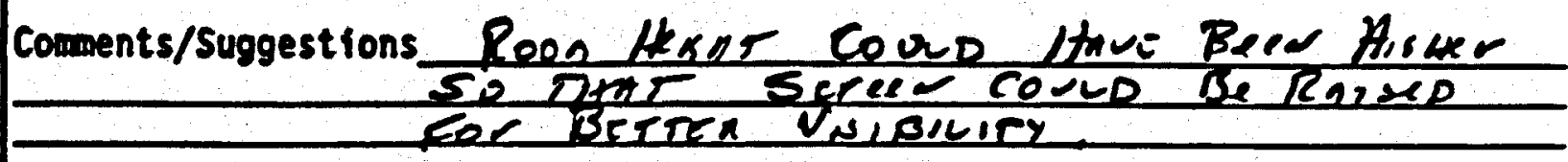


Post-Conference Evaluation Form

U.S. Department of Energy

Annual Geotheral Progran Review

April 19-21, 1988

Travelodge at the tharf

San Franciseo, CA

\begin{tabular}{|c|c|c|c|c|c|c|c|c|c|}
\hline Conference Evaluation & & & & Toood & Fair & Poor & $\cos$ & ments & \\
\hline $\begin{array}{l}\text { Fulfillment of Conferenc } \\
\text { Appropriateness of Theme } \\
\text { Adequacy of Theme Covera } \\
\text { Research Adequately Desc } \\
\text { Value of R\&D to Industry } \\
\text { Conveyed } \\
\text { Exciting New Technologie } \\
\text { Time Allotted for Quest } \\
\text { Timing of Conference } \\
\text { Location of Conference } \\
\text { Sequence of Events } \\
\text { Effectiveness of Present } \\
\text { Speaker Selection } \\
\text { Audio Visual Materials } \\
\text { Conference Materials Dis } \\
\text { Overall Conference Organ } \\
\text { Effectiveness } \\
\text { Registration Procedures }\end{array}$ & $\begin{array}{l}\text { objec } \\
\text { ibed } \\
\text { clearl } \\
\text { Deser } \\
\text { ns } \\
\text { tions } \\
\text { ributi } \\
\text { zation }\end{array}$ & tives & & $\begin{array}{l}x \\
x \\
x \\
x \\
x \\
x \\
x \\
x \\
x\end{array}$ & $\frac{x}{x}$ & & & . & \\
\hline Meeting Room Evaluation & Good & Fair & Poor & Facil & ity Ev: & aluation & Good & $\overline{\text { Fair }}$ & Poor \\
\hline $\begin{array}{l}\text { Audio Visual Equipment } \\
\text { Lighting } \\
\text { Ventilation } \\
\text { Sound Proofing } \\
\text { Furniture Set Up } \\
\text { Room Cleanl iness } \\
\text { Tea/Coffee }\end{array}$ & $\begin{array}{l}x \\
x \\
\dot{x} \\
x \\
x \\
x \\
x\end{array}$ & & & $\begin{array}{c}\text { Teleph } \\
\text { Serv } \\
\text { Transp } \\
\text { Food S } \\
\text { Hotel } \\
\text { Clean } \\
\text { Facili } \\
\text { Ancili } \\
\text { at F F }\end{array}$ & $\begin{array}{l}\text { one Mes } \\
\text { ice } \\
\text { ortatic } \\
\text { ervices } \\
\text { Room Lo } \\
\text { Up Ser } \\
\text { ty Loce } \\
\text { ary Ser } \\
\text { acilits }\end{array}$ & $\begin{array}{l}\text { ssage } \\
\text { on } \\
\text { s } \\
\text { odging } \\
\text { vices } \\
\text { ation } \\
\text { rvices } \\
y\end{array}$ & $x$ & $x$ & \\
\hline
\end{tabular}

Comments/Suggestions 
Post-Conference Evaluation Form

U.S. Department of Energy

Annual Geothernal Progran Review

April 19-21, 1988

NATIONAL LAB

Travelodge at the tharf

San Francisco, CA

\begin{tabular}{|c|c|c|c|c|c|c|c|c|c|}
\hline \multicolumn{4}{|l|}{ Conference Evaluation } & 6000 & Fair & Poor & \multicolumn{3}{|c|}{ Coments } \\
\hline \multicolumn{4}{|c|}{$\begin{array}{l}\text { Fulfillment of Conference Objectives } \\
\text { Appropriateness of Theme } \\
\text { Adequacy of Theme Coverage } \\
\text { Research Adequately Described } \\
\text { Value of R\&D to Industry Clearly } \\
\text { Conveyed } \\
\text { Excit ing New Technologies Described } \\
\text { Time AiTotted for Questions } \\
\text { Timing of Conference. } \\
\text { Location of Conference } \\
\text { Sequence of Events } \\
\text { Effectiveness of Presentations } \\
\text { Speaker Selection } \\
\text { Audio Visual Materials } \\
\text { Conference Materials Distribution } \\
\text { Overail Conference Organization } \\
\text { Effectiveness. } \\
\text { Registration Procedures }\end{array}$} & $\begin{array}{l}\check{r} \\
\check{r} \\
\sim \\
r\end{array}$ & $\begin{array}{l}\sigma \\
\sigma\end{array}$ & & & & \\
\hline Meeting Room Evaluation & 6000 & Fair & Poor & \multicolumn{3}{|c|}{ Facility Evaluation } & 6ood & Fair & Poor \\
\hline $\begin{array}{l}\text { Audio Visual Equipment } \\
\text { Lighting } \\
\text { Ventilation } \\
\text { Sound Proofing } \\
\text { Furniture Set Up } \\
\text { Room Cleanliness } \\
\text { Tea/Coffee }\end{array}$ & $\begin{array}{l}\square \\
\square \\
\vdots \\
\vdots \\
r\end{array}$ & & & \multicolumn{3}{|c|}{$\begin{array}{l}\text { Telephone Message } \\
\text { Service } \\
\text { Transportation } \\
\text { Food Services } \\
\text { Hotel Room Lodging } \\
\text { Clean Up Services } \\
\text { Facflity Location } \\
\text { Anciliary Services } \\
\text { at Facility }\end{array}$} & $\begin{array}{l}\checkmark \\
\check{r} \\
\check{r}\end{array}$ & $\checkmark$ & \\
\hline
\end{tabular}

Comnents/Suggest Ions 
Post-Conference Evaluation Form

U.S. Department of Energy

Annual Geothereal Progra Review

April 19-21, 1988

Travelodge at the tharf

NATIONAL LAB

San Francisco, CA

\begin{tabular}{|c|c|c|c|c|c|c|c|c|c|}
\hline \multicolumn{4}{|l|}{ Conference Evaluation } & Tood & Fair & Poor & $\operatorname{com}$ & Dents & \\
\hline \multicolumn{4}{|c|}{$\begin{array}{l}\text { Fulfilliment of Conference Objectives } \\
\text { Appropriateness of Theme } \\
\text { Adequacy of Theme Coverage } \\
\text { Research Adequately Described } \\
\text { Value of R\&D to Industry Clearly } \\
\text { Conveyed } \\
\text { Exciting New Technologies Described } \\
\text { Time Allotted for Questions } \\
\text { Timing of Conference } \\
\text { Location of Conference } \\
\text { Sequence of Events } \\
\text { Effectiveness of Presentations } \\
\text { Speaker Selection } \\
\text { Audio Visual Materials } \\
\text { Conference Materials Distribution } \\
\text { Overall Conference Organization } \\
\text { Effectiveness } \\
\text { Registration Procedures }\end{array}$} & $\begin{array}{l}x \\
x \\
x\end{array}$ & \begin{tabular}{l|}
$x$ \\
$x$ \\
$x$ \\
$x$
\end{tabular} & $e^{x}$ & & & \\
\hline Heeting Room Evaluation & 6ood & Fair & Poor & \multicolumn{3}{|c|}{ Facility Evaluation } & Good & Fair & $\overline{\text { Poor }}$ \\
\hline $\begin{array}{l}\text { Audio Visual Equipment } \\
\text { Lighting } \\
\text { Ventilation } \\
\text { Sound Proofing } \\
\text { Furniture Set Up } \\
\text { Room Cleanliness } \\
\text { Tea/Coffee }\end{array}$ & & & & \multicolumn{3}{|c|}{$\begin{array}{l}\text { Telephone Message } \\
\text { Service } \\
\text { Transportation } \\
\text { Food Services } \\
\text { Hotel Room Lodging } \\
\text { Clean Up Services } \\
\text { Facllity Location } \\
\text { Ancliliary Services } \\
\text { at Facllity }\end{array}$} & & & \\
\hline
\end{tabular}

Comments/Suggestions IS IT far Nartey oe is if fos DOE? 
Post-Conference Evaluation Form

U.S. Department of Energy

Annual Geothermal Progran Review

April 19-21, 1988

NATIONAL LAB

Travelodge at the tharf

San Francisco, CA

\begin{tabular}{|c|c|c|c|c|c|c|c|c|c|}
\hline \multicolumn{4}{|l|}{ Conference Evaluation } & Good & Fair & Poor & \multicolumn{3}{|c|}{ Compents } \\
\hline \multicolumn{4}{|c|}{$\begin{array}{l}\text { Fulfillment of Conference Objectives } \\
\text { Appropriateness of Theme } \\
\text { Adequacy of Theme Coverage } \\
\text { Research Adequately Described } \\
\text { Value of R\&D to Industry Clearly } \\
\text { Conveyed } \\
\text { Exciting New Technologies Described } \\
\text { Time Al Iotted for Questions } \\
\text { Timing of Conference } \\
\text { Location of Conference } \\
\text { Sequence of Events } \\
\text { Effectiveness of Presentations } \\
\text { Speaker Selection } \\
\text { Audio Visual Materials } \\
\text { Conference Materials Distribution } \\
\text { Overali Conference Organization } \\
\text { Effectiveness } \\
\text { Registration Procedures }\end{array}$} & 2 & e & & \multicolumn{3}{|c|}{ somenghes ate } \\
\hline Meeting Room Evaluation & Good & Fair| & Poor & \multicolumn{3}{|c|}{ Facflity Evaluation } & Good & Fair & Poor \\
\hline $\begin{array}{l}\text { Audio Visual Equipment } \\
\text { Lighting } \\
\text { Ventilation } \\
\text { Sound Proofing } \\
\text { Furniture Set Up } \\
\text { Room Cleanifness } \\
\text { Tea/Coffee }\end{array}$ & $\begin{array}{l}2 \\
2 \\
2 \\
2\end{array}$ & $\begin{array}{l}2 \\
2\end{array}$ & & \multicolumn{3}{|c|}{$\begin{array}{l}\text { Telephone Message } \\
\text { Service } \\
\text { Transportation } \\
\text { Food Services } \\
\text { Hotel Room Lodging } \\
\text { Clean Up Services } \\
\text { Facility Location } \\
\text { Ancillary Services } \\
\text { at Facility }\end{array}$} & $\begin{array}{l}2 \\
2 \\
z \\
z\end{array}$ & & \\
\hline
\end{tabular}

Comnents/Suggestions 
Post-Conference Evaluation For

U.S. Department of Energy

Annual Ceotheral Progra Review

April 19-21, 1988

Travelodge at the tharf

San Francisco, Ca

STATE \& LOCAL

\begin{tabular}{|c|c|c|c|c|c|c|c|c|c|}
\hline Conference Evaluation & & & & Eood & Fafr & Poor & $\cos$ & ent: & \\
\hline $\begin{array}{l}\text { Fulfillment of Conferene } \\
\text { Appropriateness of Theme } \\
\text { Adequacy of Theme Covera } \\
\text { Research Adequately Dese } \\
\text { Value of RLD to Industry } \\
\text { Conveyed } \\
\text { Excit ing New Technologie } \\
\text { Time Ailotted for Questi } \\
\text { Timing of Conference } \\
\text { Location of Conference } \\
\text { Sequence of Events } \\
\text { Effect iveness of Present } \\
\text { Speaker Selection } \\
\text { audio Visual Materials } \\
\text { Conference Materials Dis } \\
\text { Overall Conference Organ } \\
\text { Effectiveness } \\
\text { Registration Procedures }\end{array}$ & $\begin{array}{l}\text { Objec } \\
\text { e } \\
\text { ibed } \\
\text { clearl } \\
\text { Deser } \\
\text { ns } \\
\text { tions } \\
\text { ributi } \\
\text { zation }\end{array}$ & $\begin{array}{l}\text { tives } \\
\text { ibed } \\
\text { on }\end{array}$ & & $x$ & $\begin{array}{l}x \\
x \\
x \\
x \\
x \\
x \\
x \\
x \\
x \\
x \\
x \\
x \\
x\end{array}$ & $x$ & & & \\
\hline Meeting Room Evaluation & Good & Fair & Poor & Facti & ty Ev & aluation & 6000 & Faír & Poor \\
\hline $\begin{array}{l}\text { Audio Visual Equipment } \\
\text { Lighting } \\
\text { Ventilation } \\
\text { Sound Proofing } \\
\text { Furniture Set Up } \\
\text { Room Cleanl iness } \\
\text { Tea/Coffee }\end{array}$ & & $\begin{array}{l}x \\
x \\
x \\
x \\
x \\
x\end{array}$ & $x$ & $\begin{array}{l}\text { Teleph } \\
\text { Serv } \\
\text { Transp } \\
\text { food S } \\
\text { Hotel } \\
\text { Clean } \\
\text { facili } \\
\text { Ancili } \\
\text { at F }\end{array}$ & $\begin{array}{l}\text { one Me } \\
\text { ice } \\
\text { ortati } \\
\text { ervice } \\
\text { Room L } \\
\text { Up Sor } \\
\text { ty Loc } \\
\text { ary Se } \\
\text { cilit }\end{array}$ & $\begin{array}{l}\text { ssage } \\
\text { on } \\
\text { s } \\
\text { odging } \\
\text { vices } \\
\text { attion } \\
\text { rvices } \\
y\end{array}$ & $x$ & & $x$ \\
\hline
\end{tabular}

\section{coments/suivistions to \\ Teetine nopex tét bener

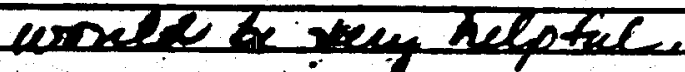

Lonly attended oxe dey of the conferena so the ce connents are not a true refection of the overall effectivenes of the Pragean. 
Post-Conference Evaluation Form

U.S. Department of Energy

Annual Ceothereal Progran Review

April 19-21, 1988

Travelodge at the tharf

San Francisco, CA.

STATE \& LOCAL

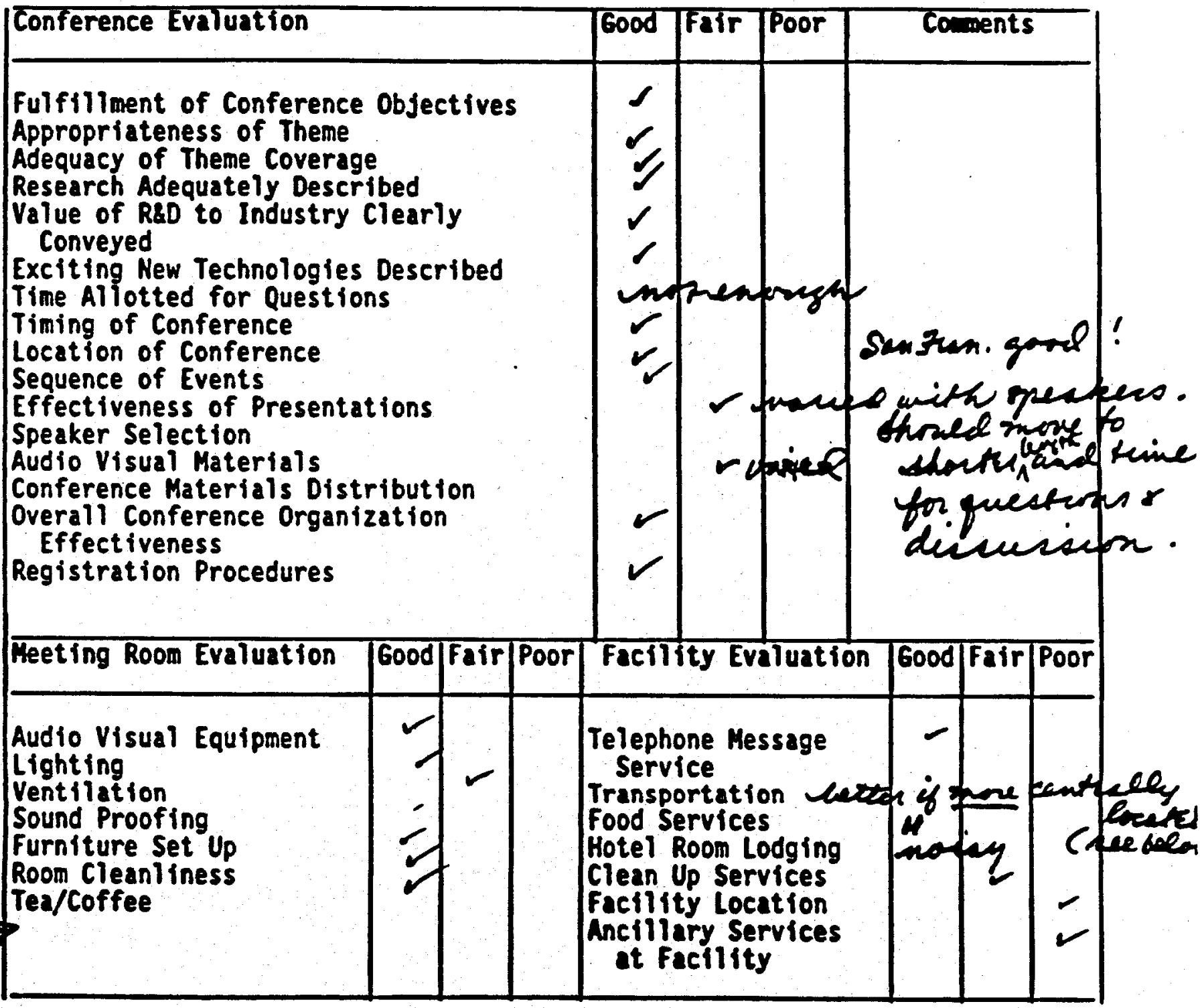

tho

reaymom

arty

outdons.

inim on

$4, a$

intint

of wet,

onin in inger

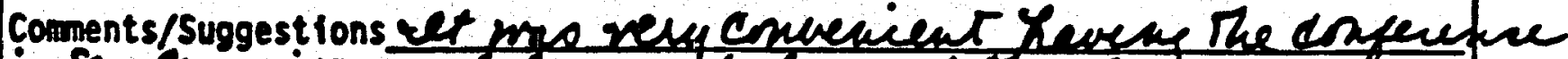

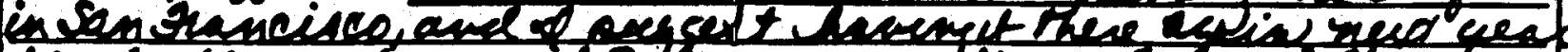

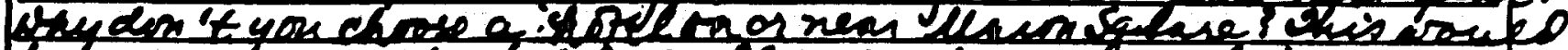

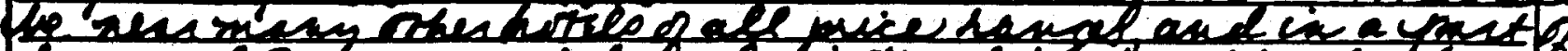

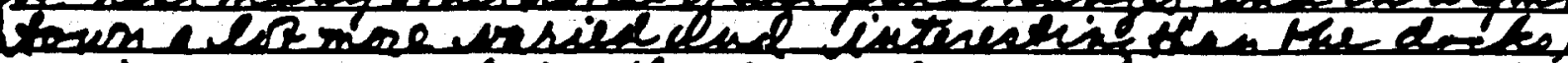

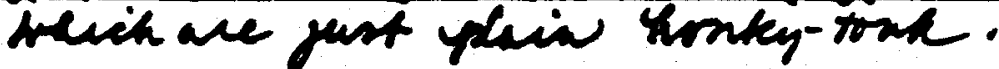

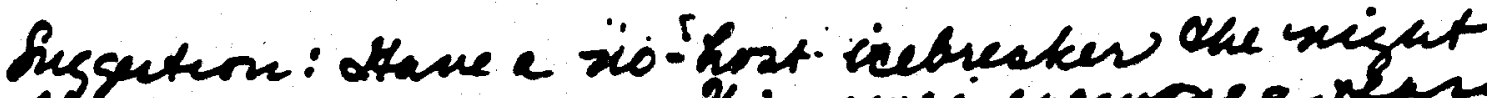
tefre the conference. Olis yues everyore a newa to mill arnind together and thle - sometheng thet

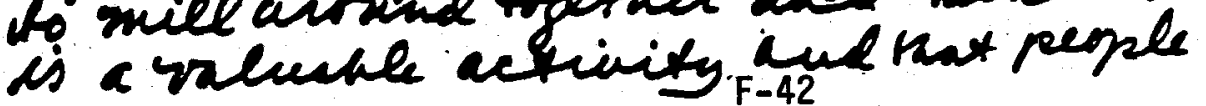
leke ding etives 
Post-Conference Evaluation Form

U.S. Department of Energy

Annual Geothermal Progran Review

Apri1 19-21, 1988

Travelodge at the tharf

San Francisco, CA

STATE \& LOCAL

\begin{tabular}{|c|c|c|c|c|c|c|c|c|c|}
\hline Conference Evaluation & & & & 6ood & Fair & Poor & $\cos$ & ments & \\
\hline $\begin{array}{l}\text { Fulfillment of Conferenc } \\
\text { Appropriateness of Theme } \\
\text { Adequacy of Theme Covera } \\
\text { Research Adequately Desc } \\
\text { Value of R\&D to Industry } \\
\text { Conveyed } \\
\text { Exciting New Technologie } \\
\text { Time Aliotted for Questi } \\
\text { Timing of Conference } \\
\text { Location of Conference } \\
\text { Sequence of Events } \\
\text { Effect iveness of Present } \\
\text { Speaker Selection } \\
\text { Audio Visual Materials } \\
\text { Conference Materiais Dis } \\
\text { Overall Conference Organ } \\
\text { Effect iveness } \\
\text { Registration Procedures }\end{array}$ & $\begin{array}{l}\text { Objec } \\
\text { ibed } \\
\text { clear } \\
\text { Deser } \\
\text { is } \\
\text { tions } \\
\text { ributi } \\
\text { zation }\end{array}$ & $\begin{array}{l}\text { etives } \\
\text { ribed } \\
\text { ion }\end{array}$ & & 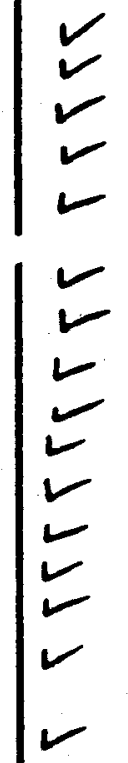 & & & & & \\
\hline Heeting Room Evaluation & Good & Fair & Poor & Facil & ity Ev & aluation & 600d & Fair & Poor \\
\hline $\begin{array}{l}\text { Audio Visual Equipment } \\
\text { Light ing } \\
\text { Vent llation } \\
\text { Sound Proofing } \\
\text { Furniture Set Up } \\
\text { Room Cleani iness } \\
\text { Tea/Coffee }\end{array}$ & $\frac{2}{2}$ & & & $\begin{array}{c}\text { Teleph } \\
\text { Ser } \\
\text { Trans } \\
\text { Food } \\
\text { Hotel } \\
\text { Clean } \\
\text { Facil } \\
\text { Anefil } \\
\text { at }\end{array}$ & $\begin{array}{l}\text { one Me } \\
\text { ice } \\
\text { ortati } \\
\text { ervice } \\
\text { Room L } \\
\text { Up Ser } \\
\text { ty Loc } \\
\text { ary Se } \\
\text { acilit }\end{array}$ & $\begin{array}{l}\text { ssage } \\
\text { on } \\
\text { s } \\
\text { odging } \\
\text { vices } \\
\text { ation } \\
\text { rvices } \\
y\end{array}$ & & & \\
\hline
\end{tabular}

\section{Couments/Suggestions}


Post-Conference Evaluation Form

U.S. Dèpartment of'Ehergy

Annual Geothermal Progran Review

Aprif 19-21; 1988

Travelodge at the tharf

San Francisco, CA

STATE \& LOCAL

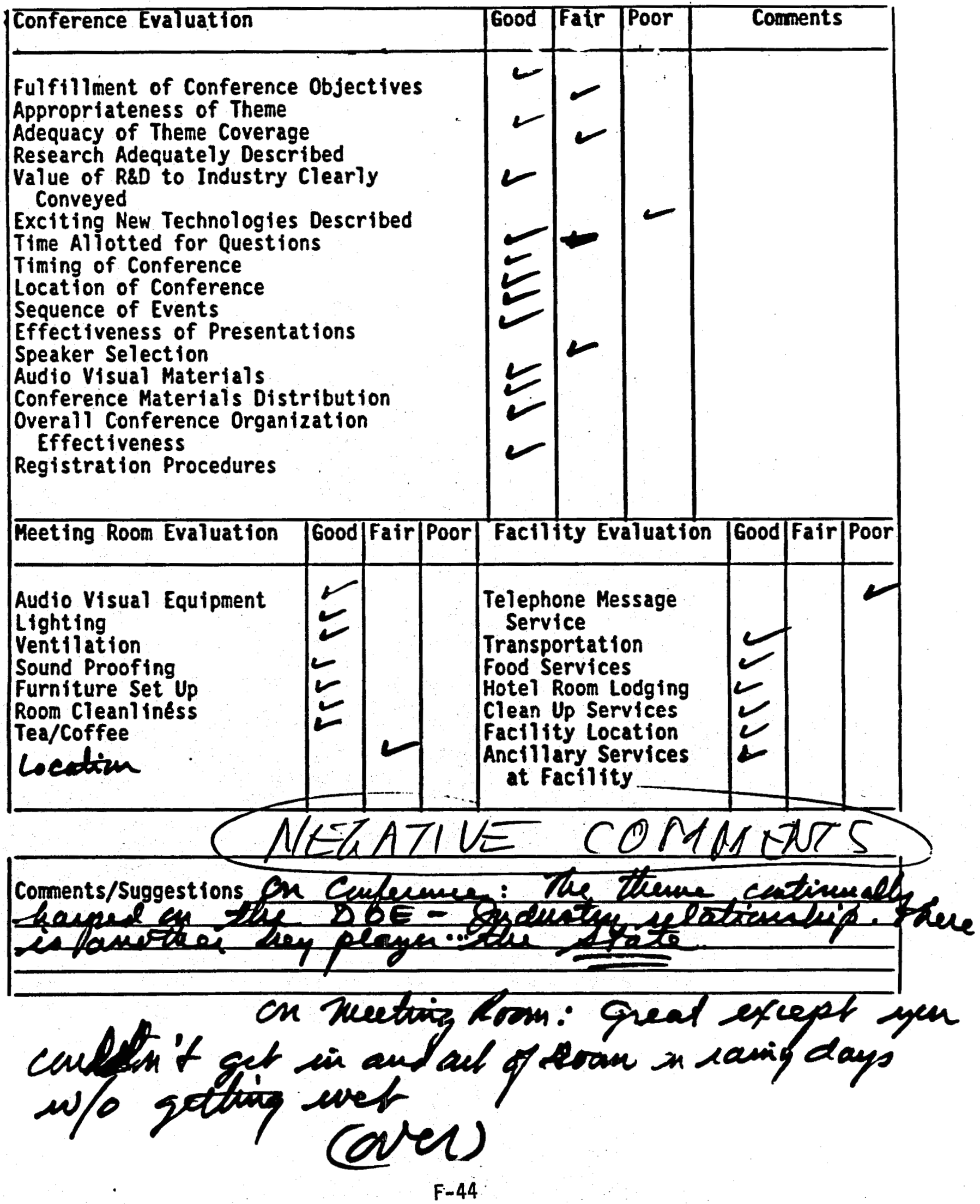


in Lotke: Very good lut they pcalped we on telepth me chaiges, uree pon

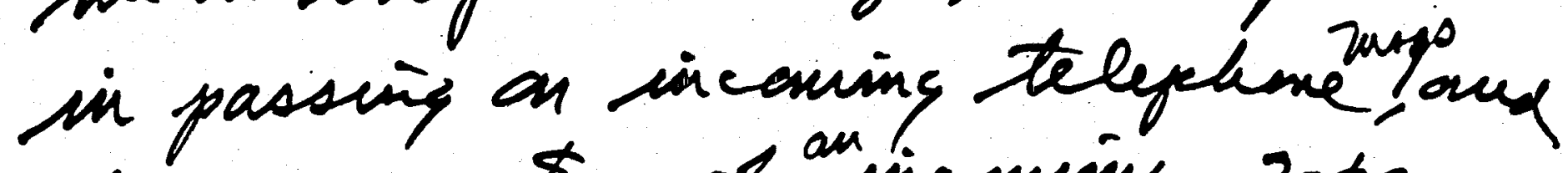
cleayed me $\$ 10$ pon incening 2-paye FAX (urlich de had to pich upat the deste)

$F-45$ 
Post-Conference Evaluation Form

U.S. Department of Energy

Annual Ceotherwal Progran Review

April 19-21, 1988

Travelodge at the tharf

San Francisco, CA

STATE \& LOCAL

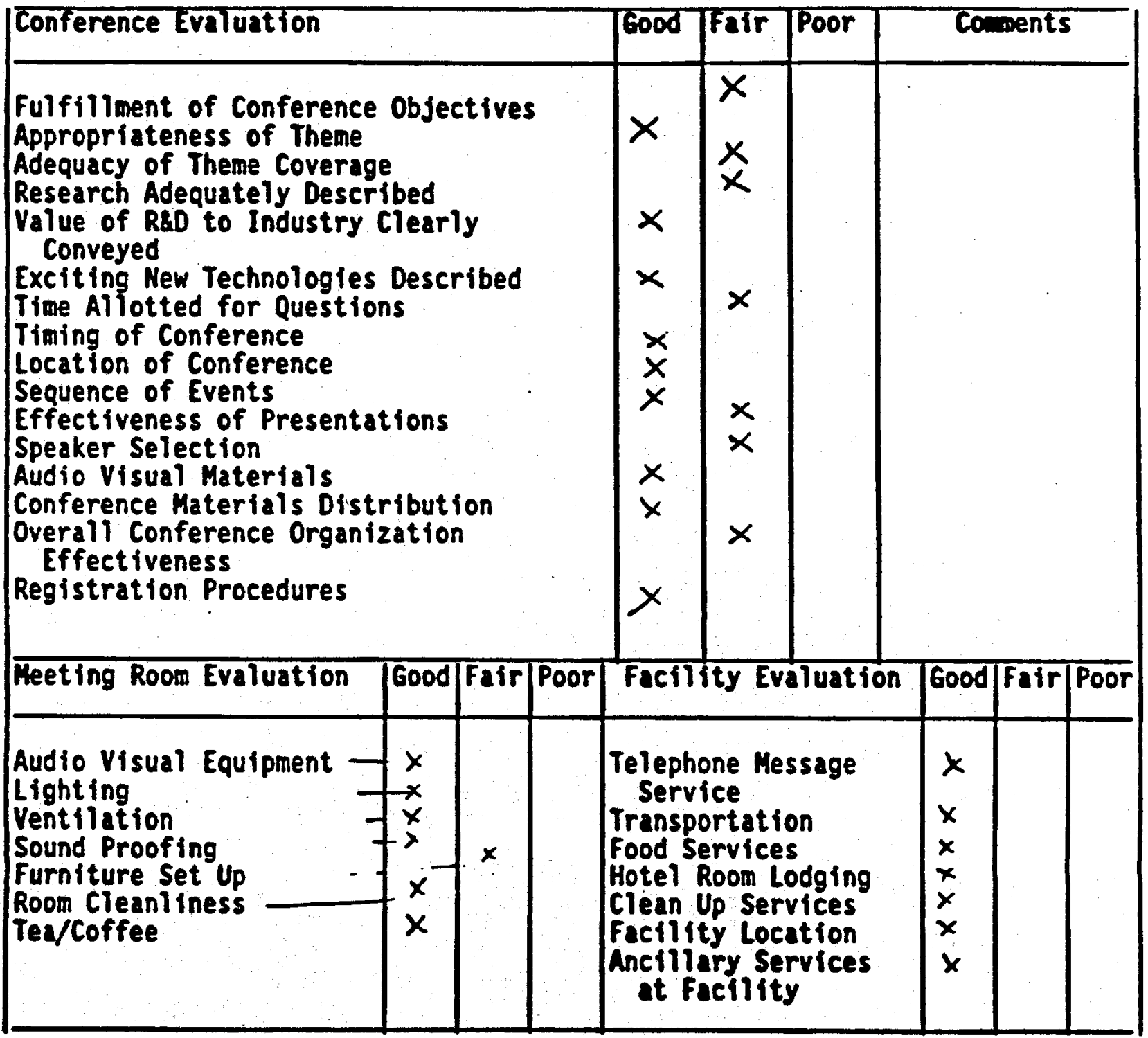

Coments/Suggestions Include sumaries of the accomplishments of state -
usnof conperative studies. The conference was too dominated by the
national laboratories. The result was inadequate debate on major
programmatic issues.


Post-Conference Evaluation. Form

U.S. Department of Energy

Annual Geothernal Progra Review

April 19-21, 1988

Travelodge at the tharf

San Franciseo, CA

STATE \& LOCAL

\begin{tabular}{|l|l|l|l|l|l|}
\hline Conference Evaluation & Cood & Fair & Poor & & Coments \\
\hline Fulfillment of Conference Objectives \\
Appropriateness of Theme \\
Adequacy of Theme Coverage \\
Research Adequately Described \\
Value of RsD to Industry Ciearly \\
Conveyed \\
Exciting New Technologies Deseribed \\
Time Aliotted for Questions \\
Timing of Conference \\
Location of Conference \\
Sequence of Events \\
Effectiveness of Presentations \\
Speaker Selection \\
Audio Visual Materials \\
Conference Materials Distribution \\
Overali Conference Organization \\
Effectiveness
\end{tabular}

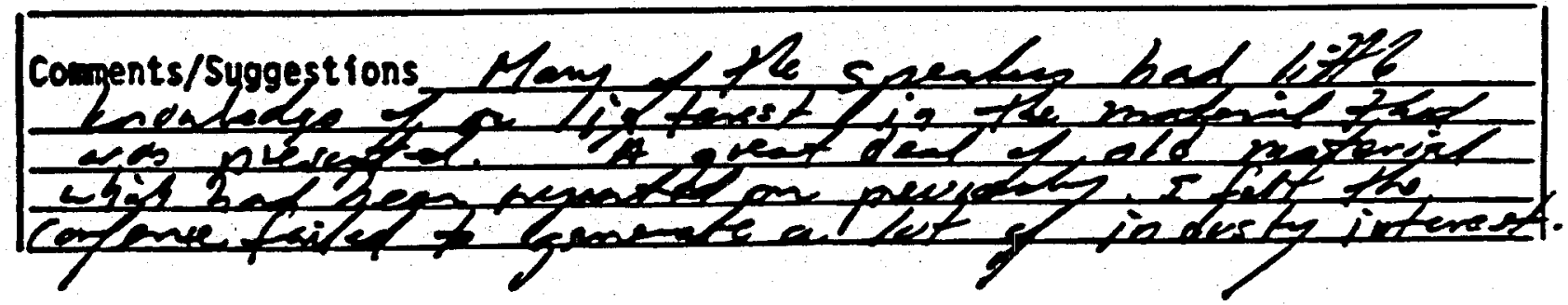


Post-Conference Evaluation Form

U.S. Department of Energy

Annual Geothermal Progra Review

April 19-21, 1988

Travelodge at the tharf

San Francisco, CA

STATE \& LOCAL

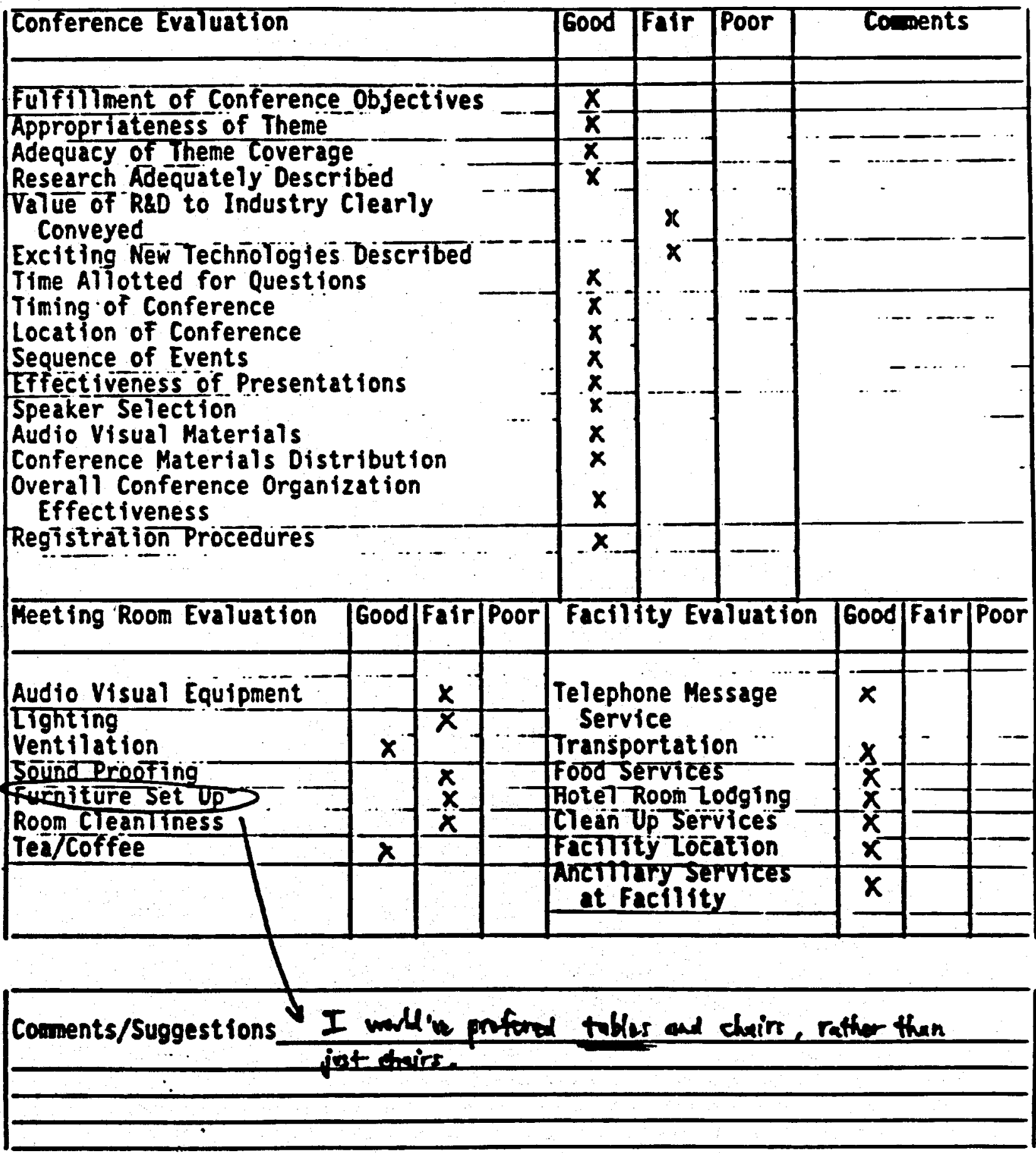


Post-Conference Evaluation Form

U.S. Department of Energy

Annual Geothernal Progran Review

April 19-21, 1988

Travelodge at the tharf

STATE \& LOCAL

San Francisco, CA

\begin{tabular}{|c|c|c|c|c|c|c|c|c|c|}
\hline \multicolumn{4}{|l|}{ Conference Evaluation } & Tood & Fair & Poor & \multicolumn{3}{|c|}{ Coments } \\
\hline \multicolumn{4}{|c|}{$\begin{array}{l}\text { Fulfillment of Conference Objectives } \\
\text { Appropriateness of Theme } \\
\text { Adequacy of Theme Coverage } \\
\text { Research Adequately Described } \\
\text { Value of R\&D to Industry Clearly } \\
\text { Conveyed } \\
\text { Exciting New Technologies Described } \\
\text { Time Aliotted for Questions } \\
\text { Timing of Conference } \\
\text { Location of Conference } \\
\text { Sequence of Events } \\
\text { Effectiveness of Presentations } \\
\text { Speaker Selection } \\
\text { Audio Visual Materials } \\
\text { Conference Materials Distribution } \\
\text { Overali Conference Organization } \\
\text { Effectiveness } \\
\text { Registration Procedures }\end{array}$} & $\begin{array}{l}x \\
x \\
x \\
x \\
x \\
x \\
x \\
x \\
x \\
x\end{array}$ & $\begin{array}{l}x \\
x\end{array}$ & $\begin{array}{l}x \\
x\end{array}$ & & & \\
\hline Meeting Room Evaluation & 6ood & Fair & Poor & \multicolumn{3}{|c|}{ Facility Evaluation } & 6ood & Fair & Poor \\
\hline $\begin{array}{l}\text { Audio Visual Equipment } \\
\text { Lighting } \\
\text { Vent ilation } \\
\text { Sound Proofing } \\
\text { Furniture Set Up } \\
\text { Room Cleani iness } \\
\text { Tea/Coffee }\end{array}$ & $\begin{array}{l}x \\
x \\
x \\
x \\
x \\
x \\
x\end{array}$ & & & \multicolumn{3}{|c|}{$\begin{array}{l}\text { Telephone Message } \\
\text { Service } \\
\text { Transportation } \\
\text { Food Services } \\
\text { Hotel Room Lodging } \\
\text { clean Up Services } \\
\text { Facillity Location } \\
\text { Anciliory Services } \\
\text { at Facility }\end{array}$} & $\begin{array}{l}x \\
x \\
x \\
x \\
x \\
x \\
x\end{array}$ & & \\
\hline
\end{tabular}

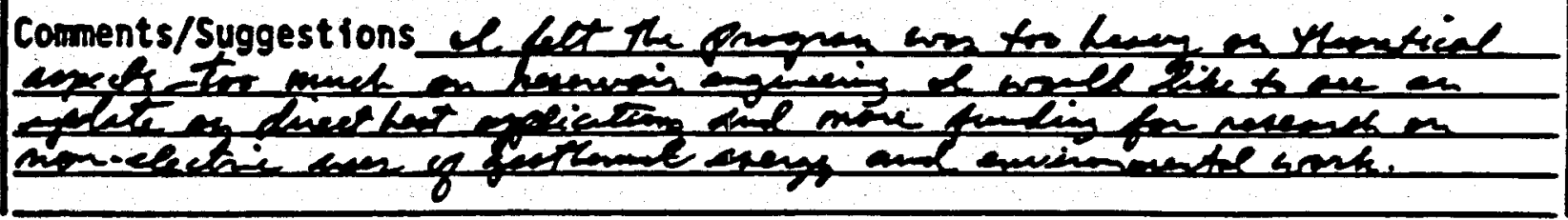


Post-Conference Evaluation Form

U.S. Department of Energy

Annual Geothereal Progran Review

Apri1 19-21, 1988

Travelodge at the tharf

San Francisco, CA

STATE \& LOCAL

\begin{tabular}{|c|c|c|c|c|c|c|c|c|c|}
\hline Conference Evaluation & & & & $600 d$ & Fair & Poor & $\operatorname{com}$ & ments & \\
\hline $\begin{array}{l}\text { Fulfillment of Conferenc } \\
\text { Appropriateness of Theme } \\
\text { Adequacy of Theme Covera } \\
\text { Research Adequately Desc } \\
\text { Value of R\&D to Industry } \\
\text { Conveyed } \\
\text { Exciting New Technologie } \\
\text { Time Aliotted for Questi } \\
\text { Timing of Conference } \\
\text { Location of Conference } \\
\text { Sequence of Events } \\
\text { Effectiveness of Present } \\
\text { Speaker Selection } \\
\text { Audio Visual Materials } \\
\text { Conference Materials Dis } \\
\text { Overall Conference Organ } \\
\text { Effectiveness } \\
\text { Registration Procedures }\end{array}$ & $\begin{array}{l}\text { Objec } \\
\text { ibed } \\
\text { iear } \\
\text { Deser } \\
\text { is } \\
\text { ions } \\
\text { ibut } \\
\text { atior }\end{array}$ & $\begin{array}{l}\text { etives } \\
\text { ry } \\
\text { ribed } \\
\text { ion }\end{array}$ & & & & & & & \\
\hline Meeting Room Evaluation & Good & Fair & Poor & Facit & Ity Ev & $\frac{1}{\text { aluation }}$ & 6ood & Fair & Poor \\
\hline $\begin{array}{l}\text { Audio Visual Equipment } \\
\text { Light ing } \\
\text { Ventilation } \\
\text { Sound Proofing } \\
\text { furniture Set Up } \\
\text { Room Cleanliness } \\
\text { Tea/Coffee }\end{array}$ & & & & $\begin{array}{c}\text { Teleph } \\
\text { Serv } \\
\text { Transp } \\
\text { Food S } \\
\text { Hotel } \\
\text { Clean } \\
\text { Facilif } \\
\text { Anclli } \\
\text { ot F }\end{array}$ & $\begin{array}{l}\text { one Me: } \\
\text { ice } \\
\text { ortatic } \\
\text { ervice } \\
\text { Room Lo } \\
\text { Up Ser } \\
\text { ty Loc } \\
\text { ary Se } \\
\text { acilit. }\end{array}$ & $\begin{array}{l}\text { ssage } \\
\text { on } \\
\text { s. } \\
\text { odging } \\
\text { vices } \\
\text { ation } \\
\text { rvices } \\
y\end{array}$ & & & \\
\hline
\end{tabular}

Coments/Suggestions 
Post-Conference Evaluation Form

U.S. Department of Energy

Annual Geothermal Progran Review

UNIVERSITY

Apri1 19-21, 1988

Travelodge at the tharf

San Francisco, CA

\begin{tabular}{|c|c|c|c|c|c|c|c|c|c|}
\hline Conference Evaluation & & & & Good & Fair & Poor & Com & iments & \\
\hline $\begin{array}{l}\text { Fulfillment of Conferenc } \\
\text { Appropriateness of Theme } \\
\text { Adequacy of Theme Covera } \\
\text { Research Adequately Desc } \\
\text { Value of R\&D to Industry } \\
\text { Conveyed } \\
\text { Exciting New Technologie } \\
\text { Time Allotted for Questi } \\
\text { Timing of Conference } \\
\text { Location of Conference } \\
\text { Sequence of Events } \\
\text { Effectiveness of Present } \\
\text { Speaker Selection } \\
\text { Audio Visual Materials } \\
\text { Conference Materials Dis } \\
\text { Overall Conference Organ } \\
\text { Effectiveness } \\
\text { Registration Procedures }\end{array}$ & $\begin{array}{l}\text { Objec } \\
\text { e } \\
\text { ibed } \\
\text { clearl } \\
\text { Descr } \\
\text { ns } \\
\text { tions } \\
\text { ribut } \\
\text { zation }\end{array}$ & $\begin{array}{l}\text { ctives } \\
\text { ly } \\
\text { ribed } \\
\text {. } \\
\text { ion }\end{array}$ & & 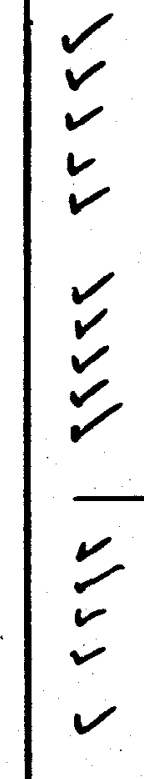 & & & $\begin{array}{l}\text { stonds } \\
\text { comper } \\
\text { meel }\end{array}$ & $\begin{array}{l}\text { ind } f \\
\text { reble } \\
\text { ings }\end{array}$ & for \\
\hline Meeting Room Evaluation & Good & Fair & Poor & Facil & ity Evo & $\frac{1}{\text { aluation }}$ & $\mid 600 d$ & Fair & Poor \\
\hline $\begin{array}{l}\text { Audio Visual Equipment } \\
\text { Lighting } \\
\text { Ventilation } \\
\text { Sound Proofing } \\
\text { Furniture Set Up } \\
\text { Room Cleanliness } \\
\text { Tea/Coffee }\end{array}$ & $\frac{r}{2}$ & $\checkmark$ & & $\begin{array}{l}\text { Teleph } \\
\text { Serv } \\
\text { Transp } \\
\text { Food S } \\
\text { Hotel } \\
\text { Clean } \\
\text { Facili } \\
\text { Ancill } \\
\text { at F F }\end{array}$ & $\begin{array}{l}\text { one Mes } \\
\text { ice } \\
\text { ortatio } \\
\text { ervices } \\
\text { Room Lo } \\
\text { Up Serv } \\
\text { ty Loca } \\
\text { ary Ser } \\
\text { acflity }\end{array}$ & $\begin{array}{l}\text { ssage } \\
\text { on } \\
\text { s } \\
\text { odging } \\
\text { vices } \\
\text { ation } \\
\text { rvices } \\
\text { y }\end{array}$ & $\frac{2}{2}$ & $\mathcal{L}$ & \\
\hline
\end{tabular}

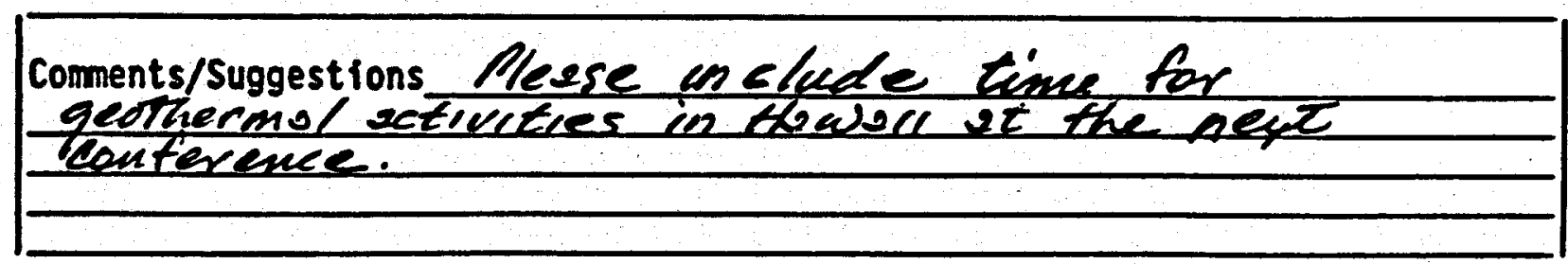




\begin{tabular}{|c|c|c|c|c|c|c|c|c|c|}
\hline Conference Evaluation & & & & $600 d$ & Fair & Poor & Com & ments & \\
\hline $\begin{array}{l}\text { Fulfillment of Conferene } \\
\text { Appropriateness of Theme } \\
\text { Adequacy of Theme Covera } \\
\text { Research Adequately Desc } \\
\text { Value of R\&D to Industry } \\
\text { Conveyed } \\
\text { Exciting New Technologie } \\
\text { Time Allotted for Questi } \\
\text { Timing of Conference } \\
\text { Location of Conference } \\
\text { Sequence of Events } \\
\text { Effectiveness of Present } \\
\text { Speaker Selection } \\
\text { Audio Visual Materials } \\
\text { Conference Materials Dis } \\
\text { Overali Conference Organ } \\
\text { Effectiveness } \\
\text { Registration Procedures }\end{array}$ & $\begin{array}{l}\text { Objec } \\
\text { ibed } \\
\text { clear } \\
\text { Deser } \\
\text { ns } \\
\text { tions } \\
\text { ributi } \\
\text { zatior } \\
\times\end{array}$ & $\begin{array}{l}\text { ctives } \\
\text { ribed } \\
\text { ion } \\
\text { ? }\end{array}$ & & $\begin{array}{l}x \\
x \\
x \\
\\
x \\
x \\
x \\
x \\
x \\
x \\
x \\
x \\
x\end{array}$ & $\begin{array}{l}x \\
x \\
x\end{array}$ & & & & \\
\hline Heeting Room Evaluation & Good & Fair & Poor & Facil & $\overline{\text { ty Ev }}$ & aluation & 60od & Fair| & Poor \\
\hline $\begin{array}{l}\text { Audio Visual Equipment } \\
\text { light ing } \\
\text { Vent liation } \\
\text { Sound Proofing } \\
\text { Furniture Set Up } \\
\text { Room Cleanliness } \\
\text { Tea/Coffee }\end{array}$ & $\begin{array}{l}x \\
x\end{array}$ & $\begin{array}{l}x \\
x \\
x \\
x\end{array}$ & $x$ & $\begin{array}{l}\text { Teleph } \\
\text { Serv } \\
\text { Transp } \\
\text { Food S } \\
\text { Hotel } \\
\text { Clean } \\
\text { Facil } \\
\text { Ancill } \\
\text { at F }\end{array}$ & $\begin{array}{l}\text { one Me } \\
\text { ice } \\
\text { ortati } \\
\text { ervice } \\
\text { Room L } \\
\text { Up Ser } \\
\text { ty Loc } \\
\text { ary Se } \\
\text { acilit }\end{array}$ & $\begin{array}{l}\text { ssage } \\
\text { on } \\
\text { s } \\
\text { odging } \\
\text { vices } \\
\text { ation } \\
\text { rvices } \\
y\end{array}$ & $\begin{array}{l}x \\
x \\
x\end{array}$ & $\begin{array}{l}\mathbf{x} \\
\mathbf{x} \\
\mathbf{x}\end{array}$ & \\
\hline
\end{tabular}

Comments/Suggestionspresentation time is not sufficient to give any detail on some exciting topics and feed back. Suggest two concurrent sessions with one to cover hydrothermal program, of wost interest to Lndustry, and a second for geopressured, EDR, magma. 
Post-Conference Evaluation Form

U.S. Departeent of Energy

Annual Geothermal Progran Review

April 19-21, 1988

UNIVERSITY

Travelooge at the tharf

San Francisco, CA

\begin{tabular}{|c|c|c|c|c|c|c|c|c|c|}
\hline Conference Evaluation & & & & $600 d$ & Fafr & Poor & $\overline{C o m}$ & ments & \\
\hline $\begin{array}{l}\text { Fulfillment of Conferenc } \\
\text { Appropriateness of Theme } \\
\text { Adequacy of Theme Covera } \\
\text { Research Adequately Desc } \\
\text { Value of R\&D to Industry } \\
\text { Conveyed } \\
\text { Exciting New Technologie } \\
\text { Time Aljotted for Quest } \\
\text { Timing of Conference } \\
\text { Location of Conference } \\
\text { Sequence of Events } \\
\text { Effectiveness of Present } \\
\text { Speaker Selection } \\
\text { Audio Visual Materials } \\
\text { Conference Materials Dis } \\
\text { Overali. Conference Organ } \\
\text { Effectiveness } \\
\text { Registration Procedures }\end{array}$ & $\begin{array}{l}\text { Objec } \\
\text { e } \\
\text { ibed } \\
\text { clear } \\
\text { Deser } \\
\text { ns } \\
\text { tions } \\
\text { ribut } \\
\text { zation }\end{array}$ & $\begin{array}{l}\text { tives } \\
\text { ibed } \\
\text { on } \\
\text { on }\end{array}$ & & $\begin{array}{l}\frac{v}{\checkmark} \\
\checkmark \\
\checkmark \\
\checkmark \\
\checkmark \\
v\end{array}$ & $\frac{1}{2}$ & & & & \\
\hline Feeting Room Evaluation & Good & Fair & Poor & Facil & ity Ev & $\frac{1}{8}$ & 600d & Fair & Poor \\
\hline $\begin{array}{l}\text { Audio Visual Equipment } \\
\text { Lighting } \\
\text { Ventilation } \\
\text { Sound Proofing } \\
\text { Furniture Set Up } \\
\text { Room Cleani iness } \\
\text { Tea/Coffee }\end{array}$ & $\begin{array}{l}\breve{v} \\
v \\
v \\
v\end{array}$ & $\checkmark$ & $\checkmark$ & $\begin{array}{l}\text { Teleph } \\
\text { Serv } \\
\text { Transp } \\
\text { Food S } \\
\text { Hotel } \\
\text { Clean } \\
\text { Facflit } \\
\text { Ancili } \\
\text { at F }\end{array}$ & $\begin{array}{l}\text { one Me } \\
\text { ice } \\
\text { ortati } \\
\text { ervice } \\
\text { ooom L } \\
\text { op Ser } \\
\text { ty Lo } \\
\text { iry Se } \\
\text { cilit }\end{array}$ & $\begin{array}{l}\text { ssage } \\
\text { on } \\
\text { s } \\
\text { odging } \\
\text { vices } \\
\text { ation } \\
\text { rvices } \\
y\end{array}$ & $\begin{array}{l}\sigma \\
\checkmark \\
\checkmark \\
\sigma \\
\checkmark \\
v \\
\sigma\end{array}$ & & \\
\hline
\end{tabular}

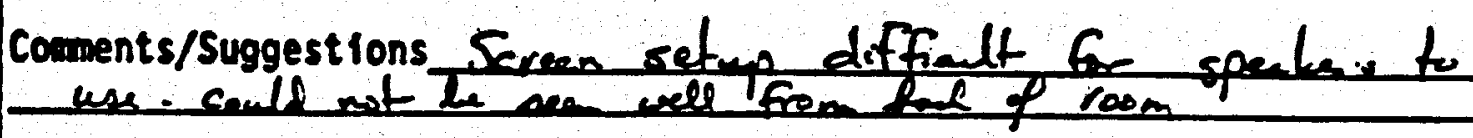


Post-Conference Evaluation Form

U.S. Department of Energy

Annual Geothereal Progran Review.

UNIVERSITY

April 19-21, 1988

Travelodge at the tharf

San Francisco, CA

\begin{tabular}{|c|c|c|c|c|c|c|c|c|c|}
\hline \multicolumn{4}{|l|}{ |Conference Evaluation } & Tood & Fair & Poor & \multicolumn{3}{|c|}{ Coments } \\
\hline \multicolumn{4}{|c|}{$\begin{array}{l}\text { Fulfillment of Conference Objectives } \\
\text { Appropriateness of Theme } \\
\text { Adequacy of Theme Coverage } \\
\text { Research Adequately Described } \\
\text { Value of RRD to Industry Clearly } \\
\text { Conveyed } \\
\text { Exciting New Technologies Described } \\
\text { Time Aliotted for Questions } \\
\text { Timing of Conference } \\
\text { Location of Conference } \\
\text { Sequence of Events } \\
\text { Effectiveness of Presentations } \\
\text { Speaker Selection } \\
\text { Audio Visual Materials } \\
\text { Conference Materiais Distribution } \\
\text { Overali Conference Organization } \\
\text { Effect iveness } \\
\text { Registration Procedures }\end{array}$} & $\checkmark$ & $\sqrt{ }$ & & & & \\
\hline Heeting Room Evaluation & 600d & Fair & Poor & \multicolumn{3}{|c|}{ Facility Evaluation } & 6ood & Fair & Poor \\
\hline $\begin{array}{l}\text { Audio Visual Equipment } \\
\text { Lighting } \\
\text { Ventilation } \\
\text { Sound Proofing } \\
\text { Furniture Set Up } \\
\text { Room Cleanliness } \\
\text { Tea/Coffee }\end{array}$ & $\begin{array}{l}\checkmark \\
\mathcal{J}\end{array}$ & $\sqrt[V]{ }$ & $\sqrt{ } \mid$ & \multicolumn{3}{|c|}{$\begin{array}{l}\text { Telephone Message } \\
\text { Service } \\
\text { Transportation } \\
\text { Food Services } \\
\text { Hotel Room Lodging } \\
\text { Clean Up Services } \\
\text { Facility Location } \\
\text { Ancillary Services } \\
\text { at Factilty }\end{array}$} & $\stackrel{V}{V}$ & & \\
\hline
\end{tabular}

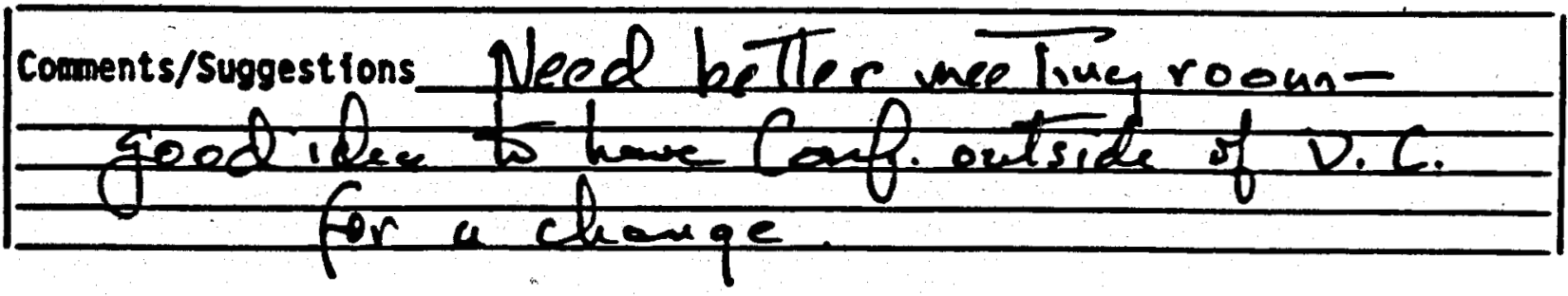


Post-Conference Evaluation Form

U.S. Department of Energy

Annual Geothermal Progras Review

Apri1 19-21, 1988

Travelodge at the tharf

UNIVERSITY

San Francisco, Ca

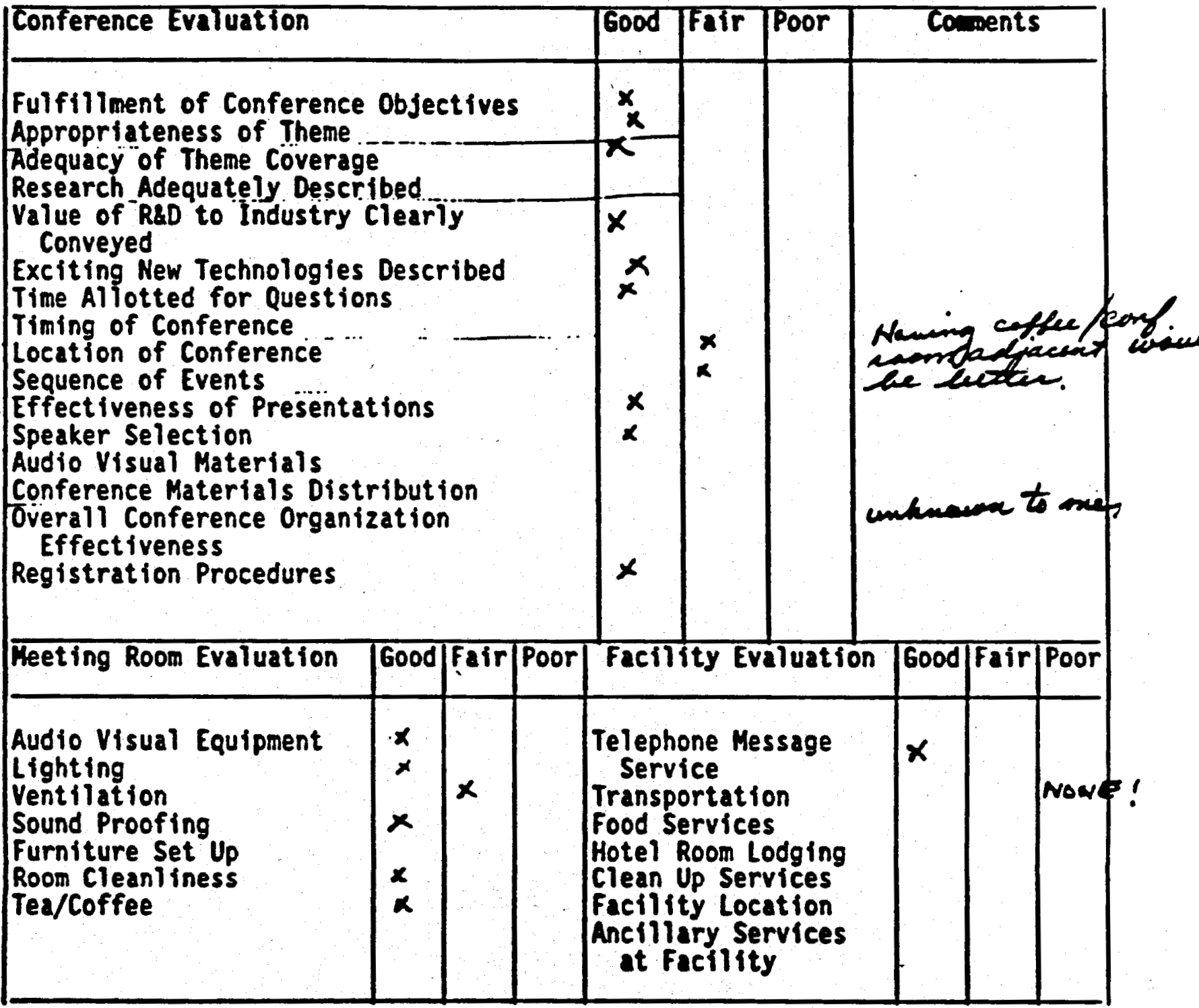

Coments/Suggestions 
Post-Conference Evaluation Form

U.S. Department of Energy

Annual Geothermal Program Review

April 19-21, 1988

Travelodge at the Wharf

San Francisco, CA

UNIVERSITY

\begin{tabular}{|c|c|c|c|c|c|c|c|c|c|}
\hline \multicolumn{4}{|l|}{ Conference Evaluation } & Good & Fair & Poor & & ments & \\
\hline \multicolumn{4}{|c|}{$\begin{array}{l}\text { Fulfillment of Conference Objectives } \\
\text { Appropriateness of Theme } \\
\text { Adequacy of Theme Coverage } \\
\text { Research Adequately Described } \\
\text { Value of R\&D to Industry Clearly } \\
\text { Conveyed } \\
\text { Exciting New Technologies Described } \\
\text { Time Allotted for Questions } \\
\text { Timing of Conference } \\
\text { Location of Conference } \\
\text { Sequence of Events } \\
\text { Effectiveness of Presentations } \\
\text { Speaker Selection } \\
\text { Audio Visual Materials } \\
\text { Conference Materials Distribution } \\
\text { Overall Conference Organization } \\
\text { Effectiveness } \\
\text { Registration Procedures }\end{array}$} & $\begin{array}{l}x \\
x \\
x \\
x \\
x \\
\\
x \\
x \\
x \\
x \\
x \\
x \\
x \\
x \\
x \\
x \\
x \\
x \\
x\end{array}$ & & & & & \\
\hline Meeting Room Evaluation & Good & Fair & Poor & \multicolumn{3}{|c|}{ Facility Evaluation } & Good & Fair & Poor \\
\hline $\begin{array}{l}\text { Audio Visual Equipment } \\
\text { Lighting } \\
\text { Ventilation } \\
\text { Sound Proofing } \\
\text { Furniture Set Up } \\
\text { Room Cleanl iness } \\
\text { Tea/Coffee }\end{array}$ & $\begin{array}{l}x \\
x \\
x \\
x \\
x \\
x \\
x \\
x\end{array}$ & & & \multicolumn{3}{|c|}{$\begin{array}{l}\text { Telephone Message } \\
\text { Service } \\
\text { Transportation } \\
\text { Food Services } \\
\text { Hotel Room Lodging } \\
\text { Clean Up Services } \\
\text { Facility Location } \\
\text { Ancillary Services } \\
\text { at Facility }\end{array}$} & $N / A$ & & \\
\hline
\end{tabular}

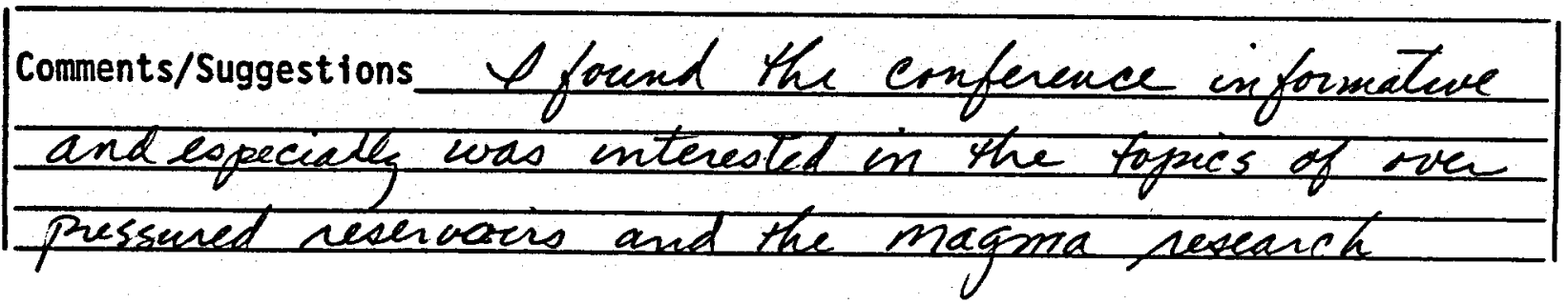


Post-Conference Evaluation Form

U.S. Department of Energy

Annual Geothermal Progran Review

Apri1 19-21, 1988

UNKNOWN

Travelodge at the tharf

San Francisco, CA

\begin{tabular}{|c|c|c|c|c|c|c|c|c|c|}
\hline Conference Evaluation & & & & $600 d$ & fFafr & Poor & $\mathrm{CO}$ & ments & \\
\hline $\begin{array}{l}\text { Fulfillment of Conferenc } \\
\text { Appropriateness of Theme } \\
\text { Adequacy of Theme Covera } \\
\text { Research Adequately Desc } \\
\text { Value of R\&D to Industry } \\
\text { Coniveyed } \\
\text { Exciting New Technologie } \\
\text { Time Allotted for Questi } \\
\text { Timing of Conference } \\
\text { Location of Conference } \\
\text { Sequence of Events } \\
\text { Effectiveness of Present } \\
\text { Speaker Selection } \\
\text { Audio Visual Materials } \\
\text { Conference Materials Dis } \\
\text { Overall Conference Organ } \\
\text { Effectiveness } \\
\text { Registration Procedures }\end{array}$ & $\begin{array}{l}\text { Objec } \\
\text { ibed } \\
\text { clearl } \\
\text { Descr } \\
\text { is } \\
\text { tions } \\
\text { ributi } \\
\text { zation }\end{array}$ & $\begin{array}{l}\text { ctives } \\
\text { ribed } \\
\text { ion } \\
\text { in }\end{array}$ & & $\begin{array}{l}\sigma \\
\sigma \\
r \\
\checkmark \\
r \\
r \\
r \\
r \\
r\end{array}$ & & & ce be & $\mu$ & - \\
\hline Meeting Room Evaluation & Good & Fair & Poor & Facil & ity Ev & luation & Good & Fair & Poor \\
\hline $\begin{array}{l}\text { Audio Visual Equipment } \\
\text { Lighting } \\
\text { Ventilation } \\
\text { Sound Proofing } \\
\text { Furniture Set Up } \\
\text { Room Cleaniliness } \\
\text { Tea/Coffee }\end{array}$ & $\frac{2}{2}$ & & & $\begin{array}{l}\text { Teleph } \\
\text { Sery } \\
\text { Transp } \\
\text { Food } \\
\text { Hotel } \\
\text { Clean } \\
\text { Facil } \\
\text { Ancill } \\
\text { at }\end{array}$ & $\begin{array}{l}\text { one Me } \\
\text { ice } \\
\text { ortati } \\
\text { ervice } \\
\text { Room L } \\
\text { Up Ser } \\
\text { ty Loc } \\
\text { ary Se } \\
\text { acilit }\end{array}$ & $\begin{array}{l}\text { ssage } \\
\text { lon } \\
\text { s } \\
\text { odging } \\
\text { vices } \\
\text { ation } \\
\text { rvices } \\
y\end{array}$ & $\checkmark$ & & \\
\hline
\end{tabular}

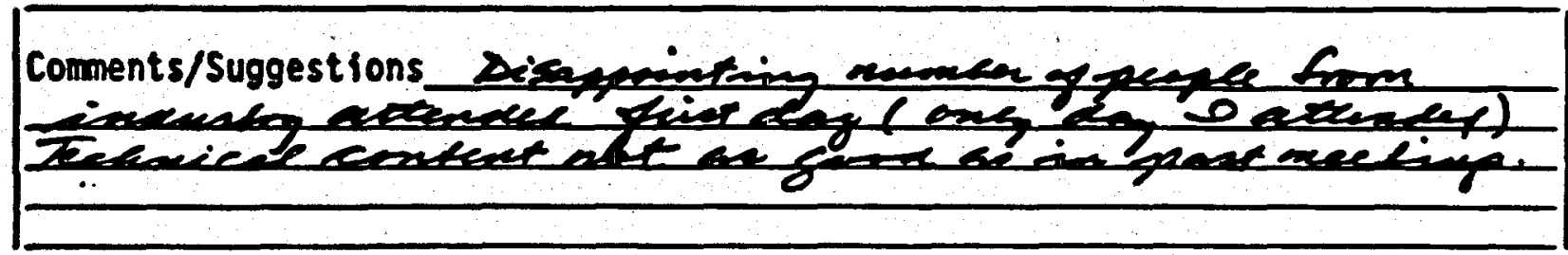




\section{APPENDIX $\mathbf{G}$}

COVER AND TABLE OF CONTENTS

FOR PR VI PROCEEDINGS

G-1 


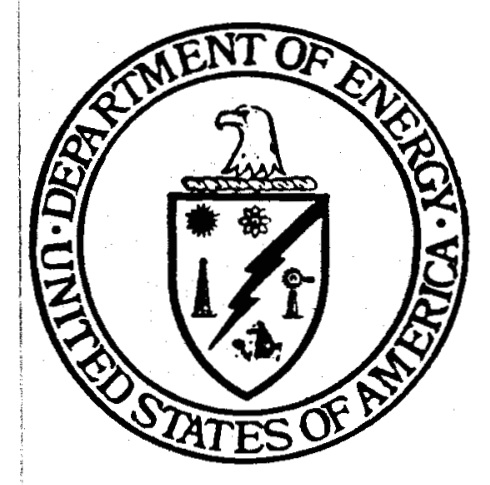

\title{
Proceedings
}

\section{GEOTHERMAL PROGRAM REVIEW VI}

\section{"Beyond Goals And Objectives"}

\author{
April 19-21, 1988 \\ SAN FRANCISCO, CA
}

Sponsored by:

U.S. DEPARTMENT OF ENERGY

Assistant Secretary, Conservation and Renewable Energy

Geothermal Technology Division 


\section{SESSION I \\ Overview}

Chairperson: John E. Mock, Director, Geothermal Technology Division, U.S. Department of Energy

Opening Remarks: Renewable Energy Contribution to the National Energy Future

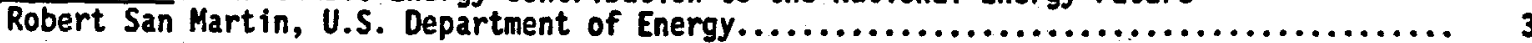

Keynote Address: Industry Perspective on the Federal Geothermal R\&D Program James B. Combs, Geothermal Resources International, Inc......................

Introduction to the Theme: Beyond Goals and Objectives John E. Mock, Geothermal Technology Division, U.S. Department of Energy.............. 17

Regional Aspects of Geothermal Energy Development Martha Dixon, San Francisco Operations Office, U.S. Department of Energy...............

\section{SESSION II}

\section{Hydrothermal Research Program Objectives}

Chairperson: Susan Prestwich, Idaho Operations office, U.S. Department of Energy

Increasing Reservoir Confirmation and Well Siting Confidence through Hydrothermal Earth Science Research

Dennis L. Nielson and Phillip M. Wright, University of Utah Research Institute........ 33

Reducing Long-Term Reservoir Performance Uncertainty Marcelo Lippmann, Lawrence Berkeley Laboratory.

Understanding Geothermal Reservoir Dynamics Roland Horne, Stanford University.

Geophysical Measurement of Geothermal Fluid Production and Injection Paul Kasameyer, Lawrence Livermore National Laboratory.......................... 53

Optimizing Reservoir Management through Fracture Modeling Joel Renner, Idaho Hational Engineering Laboratory $\ldots \ldots \ldots \ldots \ldots \ldots \ldots \ldots$

Decreasing Energy Conversion Costs with Advanced Materials

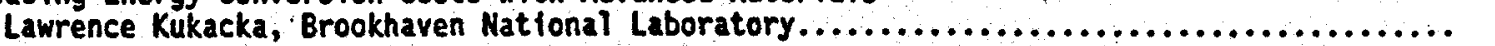

Biological Solutions to Waste Management Eugene Premuzic, Brookhaven National Laboratory.............................

The Prediction of Chemical Scaling in Geothermal Power Operations

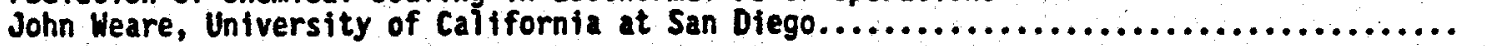

Honitoring the Haterials and Chemistry of Geothermal Plant Donaid Shannon, Battelle Paclfic Northwest Laboratory. 


\section{SESSION III \\ Geopressured-Geothermal Research Program Objectives}

Chairperson: Susan Prestwich, Idaho Operations Office, U.S. Department of Energy

Research to Understand and Predict Geopressured Reservoir Characteristics with Confidence

Susan Stiger, Idaho National Engineering Laboratory.......................... 93

Potential for Utilizing the Geopressured-Geothermal Resource

C.R. Featherston, Eaton Operating Co., Inc............................... 99

DOE/EPRI Hybrid Power System

Susan Stiger, Idaho National Engineering Laboratory ......................... 105

\section{SESSION IV}

Hot Dry Rock Research Program Objectives

Chairperson: George P. Tennyson, Jr., Albuquerque Operations Office, U.S. Department of Energy

Hot Dry Rock Research Program Objectives Session: Introduction

George P. Tennyson, Jr., U.S. Department of Energy .........................111

Hot Dry Rock Fracture Propagation and Reservoir Characterization

Hugh Nurphy, Los Alamos National Laboratory................................ 113

Prospects for Hot Dry Rock in the Future

Michael Berger, Los Alamos National Laboratory.............................. 123

Orilling and Completion at Fenton Hill

Hugh Murphy and Robert Hendron, Los Alamos National Laboratory................... 133

Hot Dry Rock Venture Risks Assessment

Frank Cockrane, Bechtel National Inc.

\section{SESSION $\mathbf{V}$ \\ Magma Energy Research Program Objectives}

Chairperson: George P. Tennyson, Jr., Albuquerque Operations Office, U.S. Department of Energy

Magma Energy Research Program Objectives Session: Introduction

George P. Tennyson, Jr., U.S. Department of Energy.

Research to Tap the Crustal Magma Source

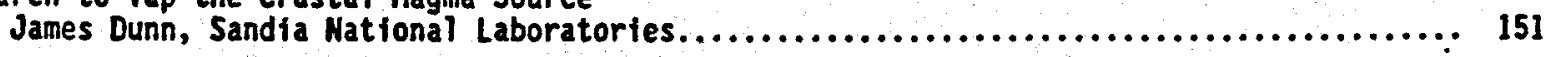

Recent Advances in Magma Energy Extraction

T.Y. Chu, Sandia National Laboratories.................................. 155

Drtiling Program for Long Valley Caldera

John Finger, Sandia National Laboratories. 


\section{SESSION VI}

\section{Special Issues Session}

Chairperson: Ralph Burr, Geothermal Technology Division, U.S. Department of Energy

Quantifying the Cost-of-Power Impacts of Federal Geothermal R\&D

Richard Traeger, Sandia National Laboratories, and Daniel Entingh, Meridian Corporation........................................................ 167

Government/Industry Cooperative Arrangements .- National Academy of

Sciences Recommendations

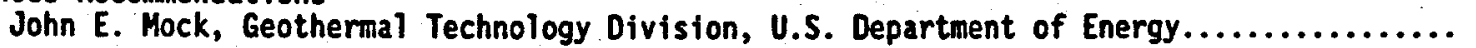

Government-Industry Cooperation at Work: Example of the Geothermal Orilling Organization James Dunn, Sandia National Laboratories........................................ 181

International Market Opportunities for Geothermal Companies

Linda Joy DeBoard, Energy Technology Export Program, California Energy Commission....... 183

Closing Remarks

Ronald Loose, Office of Renewable Energy Technologies, U.S. Department of Energy....... 191

Final Agenda......................................................... 193

List of Participants....................................................... 199 